\title{
رقابة بورصة القيم المنقولة على شركات المساهمة في التشريع الجزائري
}

\author{
خلفاوي عبد الباقي \\ كلية الحقوق, قسم القانون الخاص \\ جامعة الاخوة منتوري قسنطينة
}

إن مصادر الموارد المالية للدولة هو نشاطها

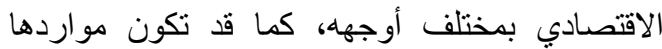

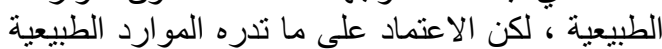

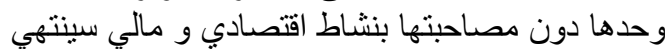

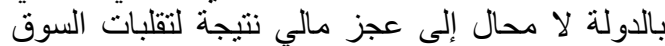

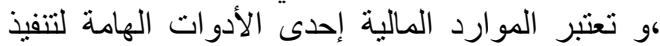

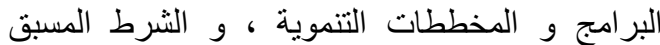

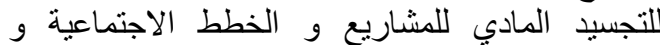

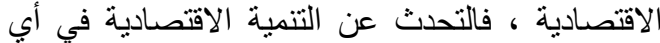

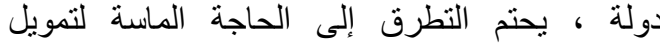
المؤسسات الاقتصادية ، عمومية كانت أو خاصة.

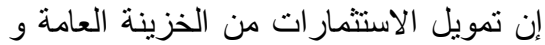

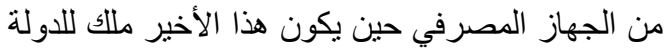

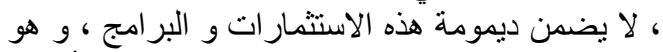

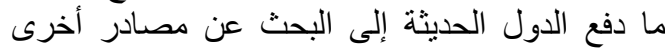

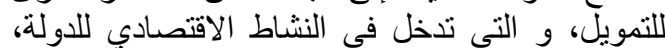

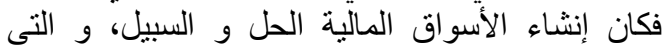
تعتمد على الادخار في القيم المنقولة.

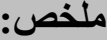

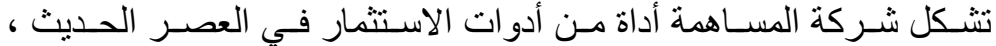

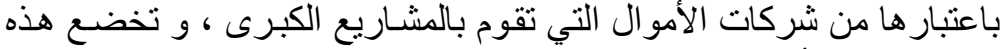

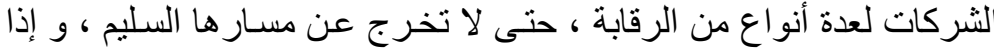

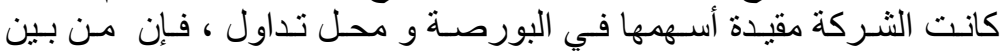

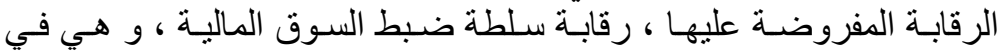

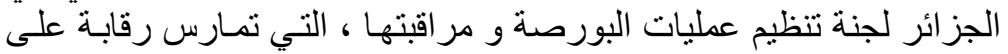

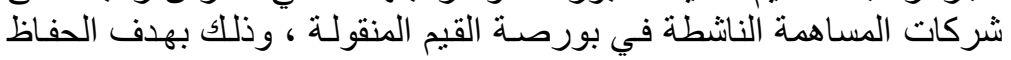
على حقوق المستثمرين و المدخرين في القيم المنقولة.

و تمارس الرقابة على شركات المساهمة سواء في سوق الاصدسار ، أو في ألي

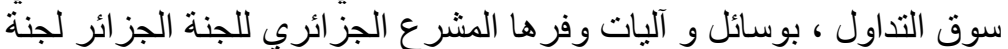

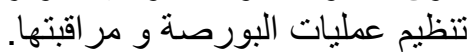

\begin{abstract}
:
La société par action est un outil d'investissement dans l'économie moderne, comme l'une des sociétés commerciales qui réalisent des projets importants, et ces sociétés sont soumises à plusieurs types de contrôle, afin de ne pas déraper le chemin, et si la société restreint ses actions à la bourse, Parmi les contrôles qui lui sont imposés, le contrôle de l'autorité de marché financier, en Algérie c'est La Commission d'Organisation et de Surveillance des Opérations de Bourse (COSOB), qui contrôle les sociétés par actions actives en bourse, afin de préserver les droits des investisseurs et des épargnants sur les valeurs mobiliers.
\end{abstract}

Le contrôle exercé par la COSOB sur les sociétés par actions, que ce soit sur le marché émetteur ou sur le marché des transactions des valeurs mobiliers, par des moyens et des mécanismes fournis par le législateur algérien au COSOB. 
إن الدعم المـالي لجمهور المـخرين يعتبر جد هـام لمواجهة تحديات المنافسـة التي

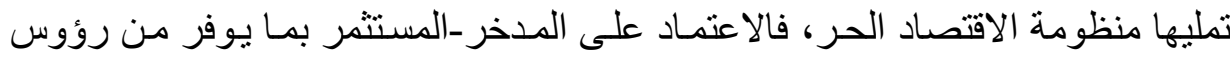

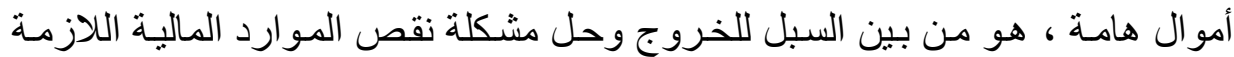

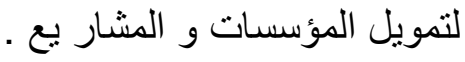

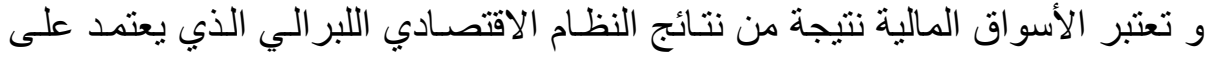

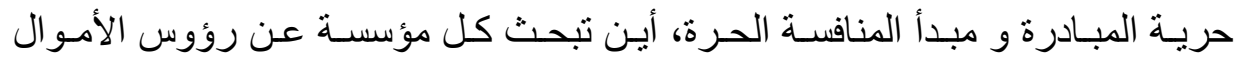

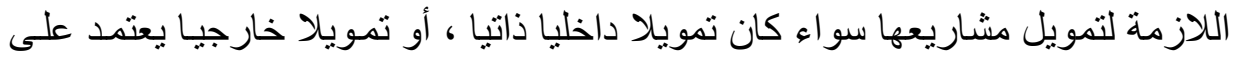

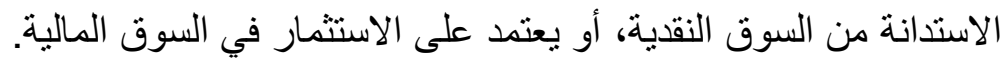

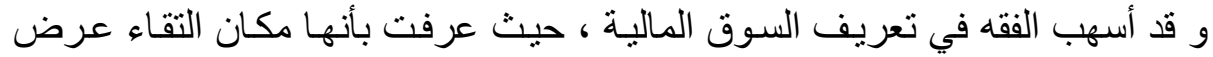

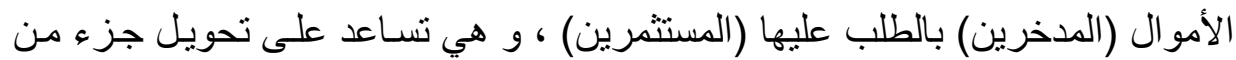

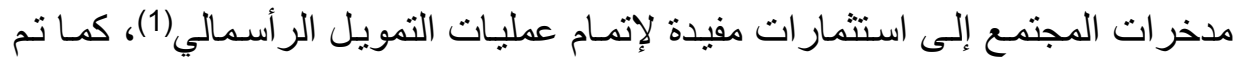

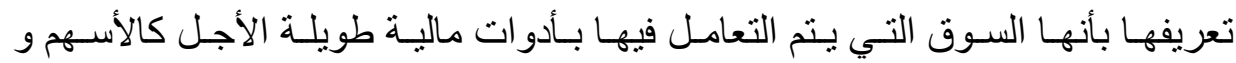

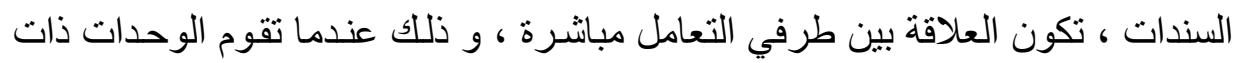

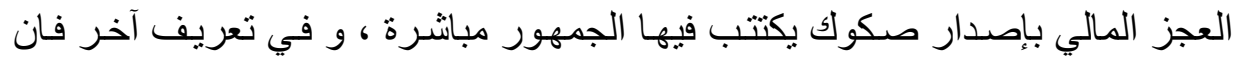

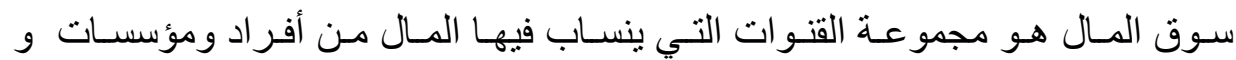
قطاعات في المجتمع إلى أفراد و مؤسسات و قطاعات أخرى في المجتمع(2) ، كما أنها

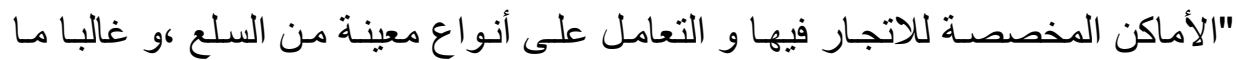

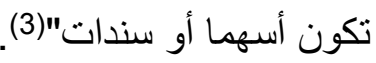

و عن تعريف المدخر فهو " الثخص الحائز على رأس مـال مخصص لاستعمالات خارجة عن نشاطه المهني أو لتخصصده، رغدية في تحقيق الربح (4).

و إذا كان الاستثمار و الادخار في سوق المال واسع وله عدة أثكال فإن موضو عنا

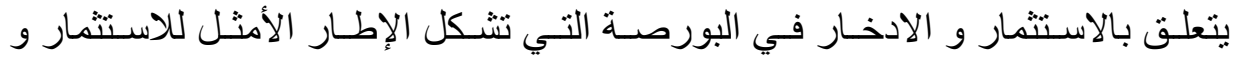

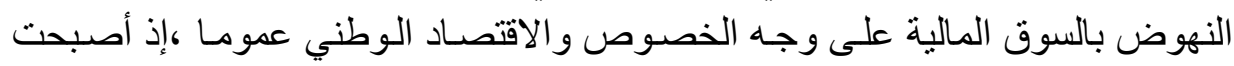

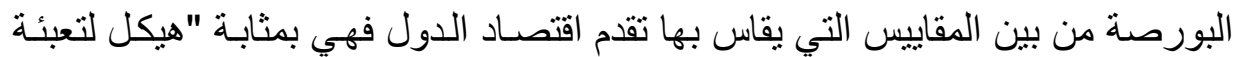

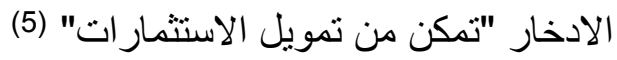

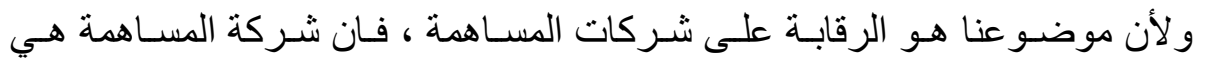

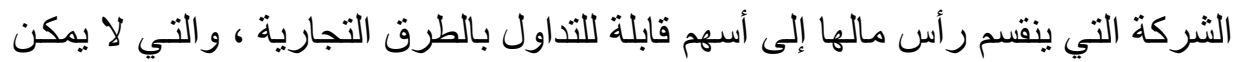

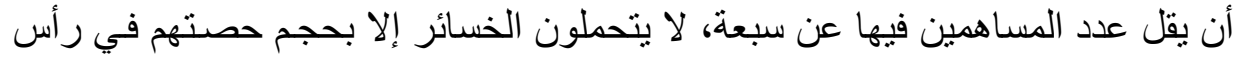




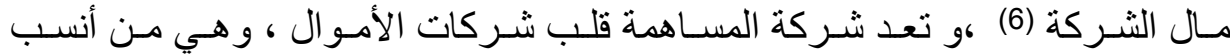

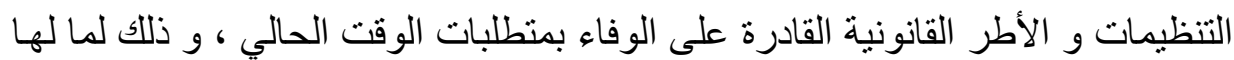

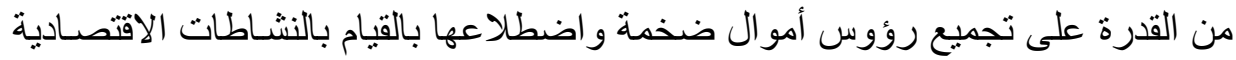

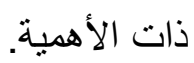

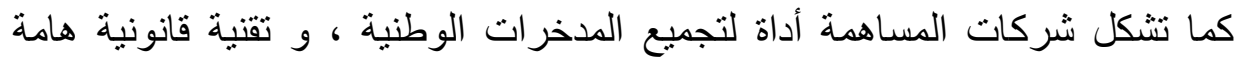

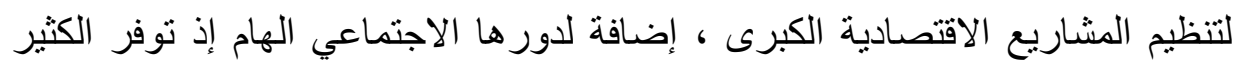

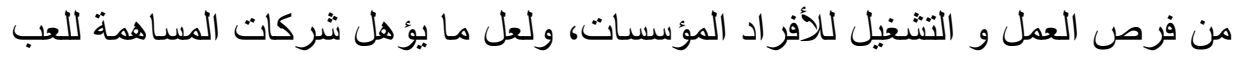
هذا الدور الهام هو قدرتها للوصول و بأيسر السبل لتكوين رؤوس أمو ال طائلة لإمكانية ألمانية

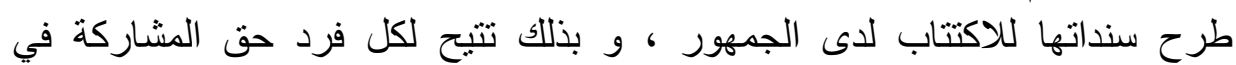

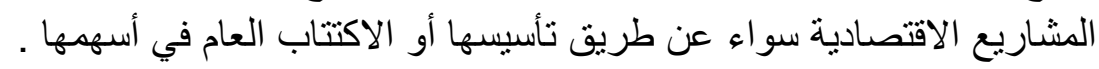

و لعل ما يفسر قدرة شركات المساهمة على تجميع رؤوس أموال ضخمة هو ما يتميز

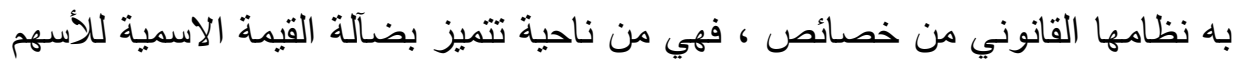

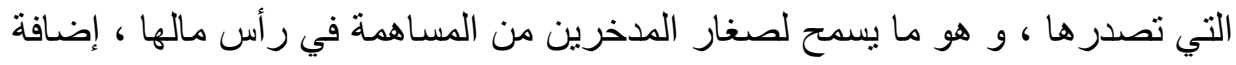

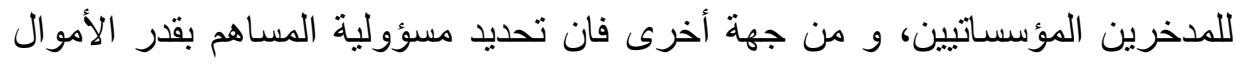

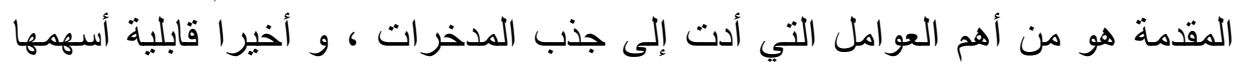

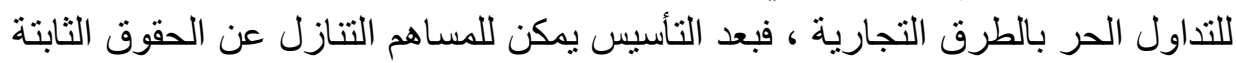

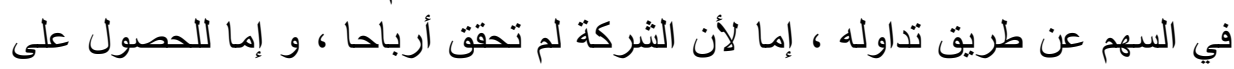

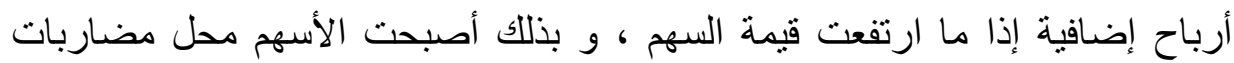

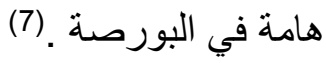

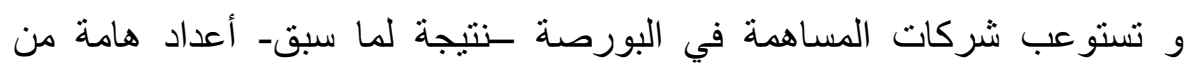

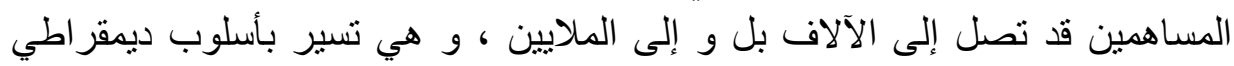

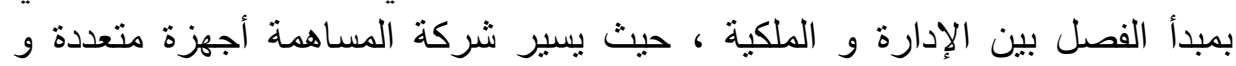

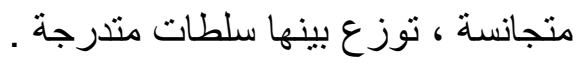

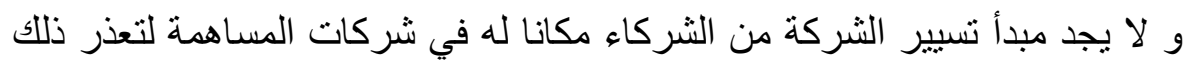

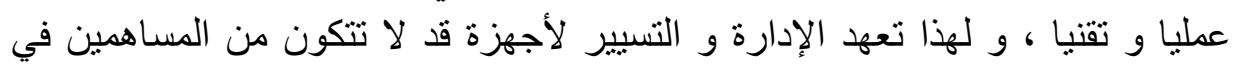

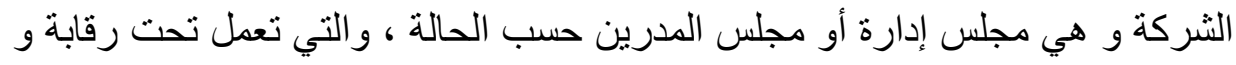

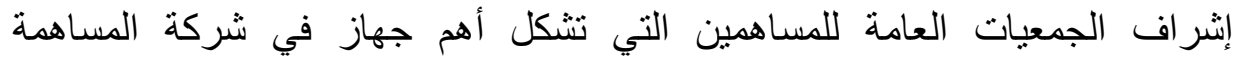
باعتبارها تتكون من ملاك الثركة الذين يقررون كل ما يتعلق بحياتها و نشاطها و

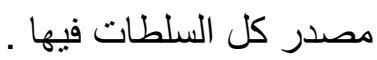


و عليه فقد أقرت التشريعات بحق المساهم في رقابة شركة المساهمة ، هذه الرقابة

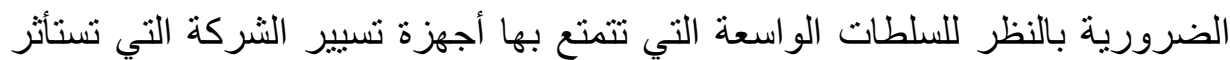

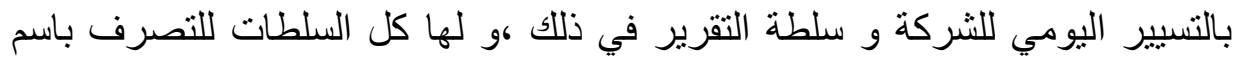

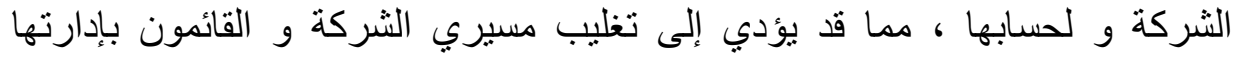

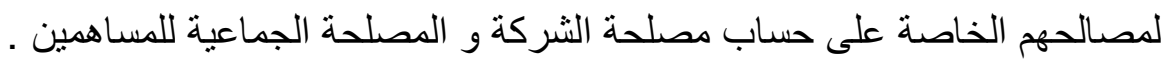
ووسائل رقابة المساهم للشركة هي أساسا الحقوق التي أقرتها له التشريعات الحديثة

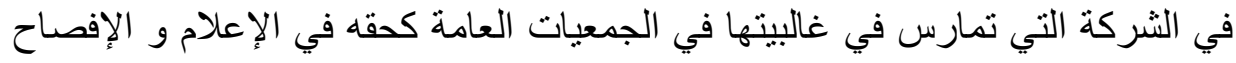
و حقه في المشاركة و التصويت في الجمعيات العامة ، و و حقه في مسائلة الجهاز

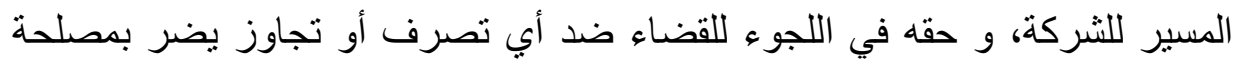
الثركة أو بالمصلحة الجماعية للمساهمين.

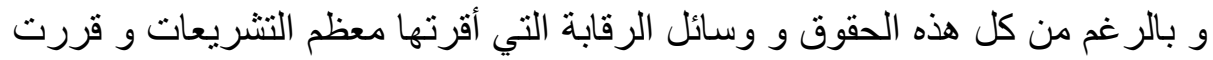

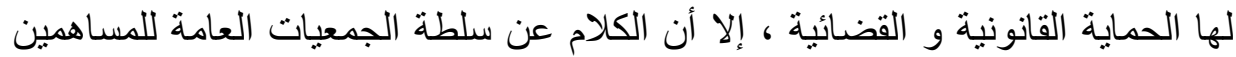

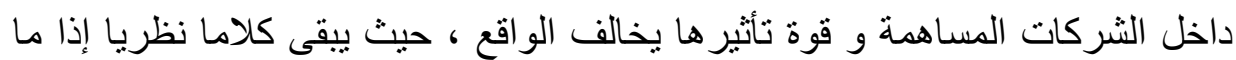

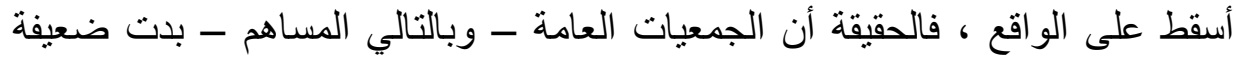
أمام مجلس إداري ما انفكت قوته تزداد ، فقد أصبح مسيروا الثركة ولئ وات القائمين بإدارتها

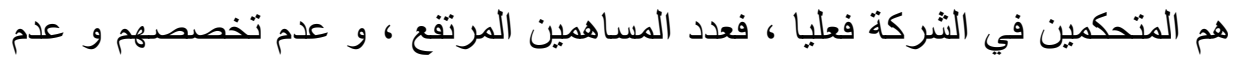

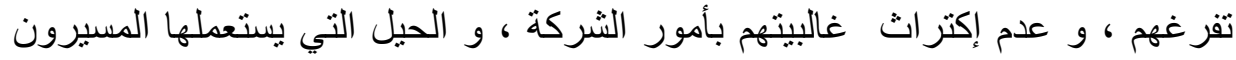

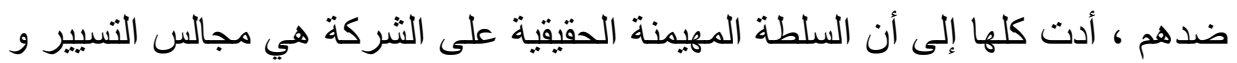

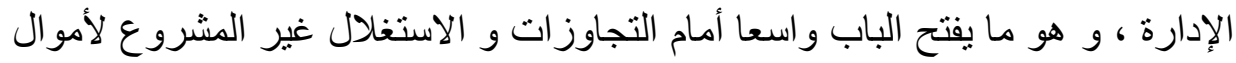

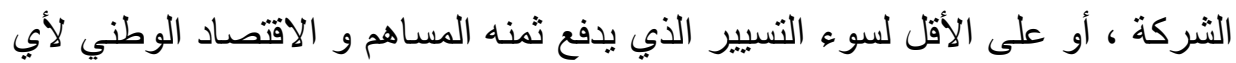
دولة .

لكل ما سبق فان رقابة أخرى ذهبت القو انين و التشريعات إلى فرضها على شركات

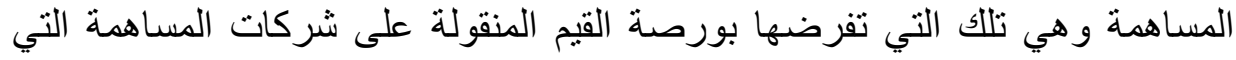
تكون أسهها مقيدة في البورصة ، و و الهدف هو تحقيق حماية اكبر للمساهين

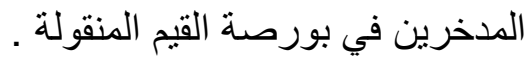

إذ المدخر الذي يستثر أمواله في القيم المنقولة ن هو عادة ذلك الثخص غير المهني

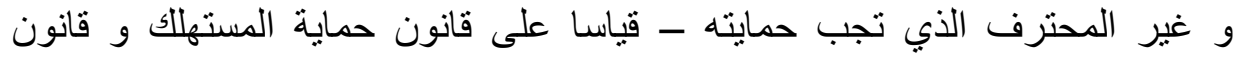

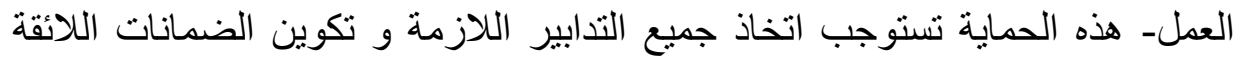


من اجل تأمين المدخر من المخاطر غير التجارية التي يمكن أن تمس استثماره في القيم

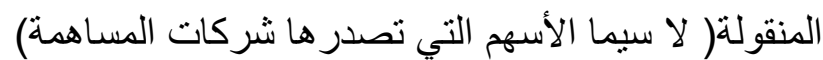

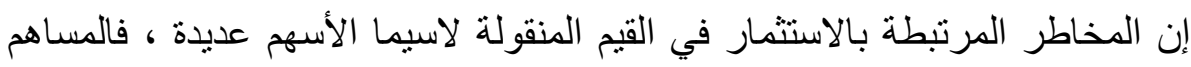

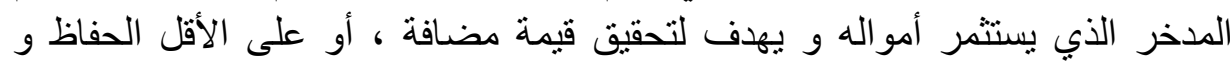

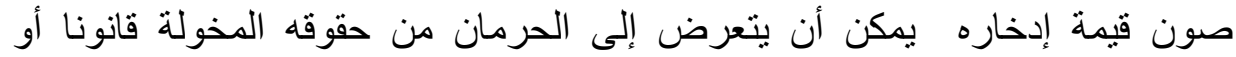

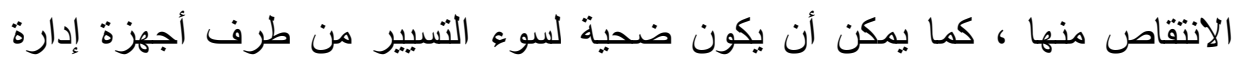

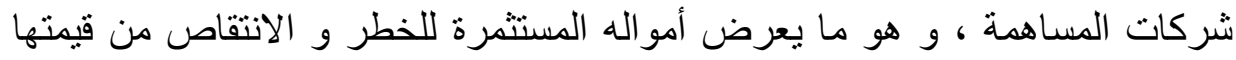

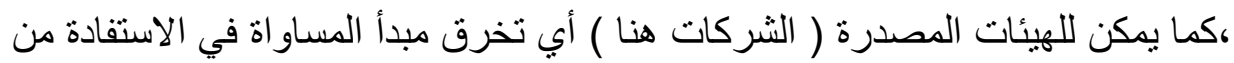

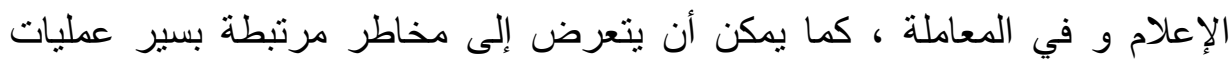

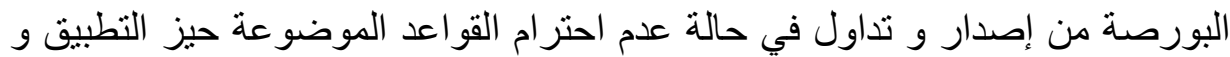

التي من شانها ضمان المساو اة بين المستثمرين في السوق و و حمايتهم (8) .

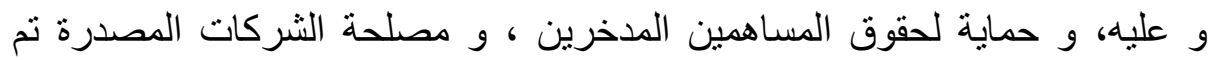

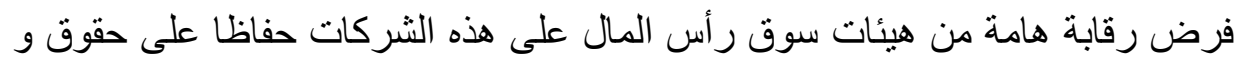

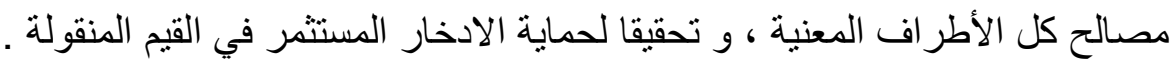

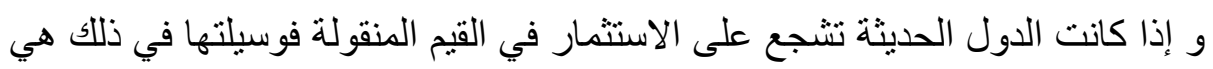

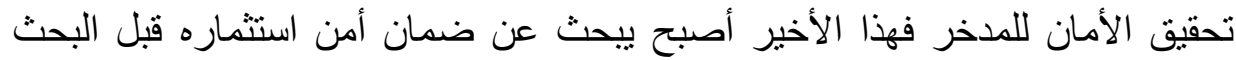

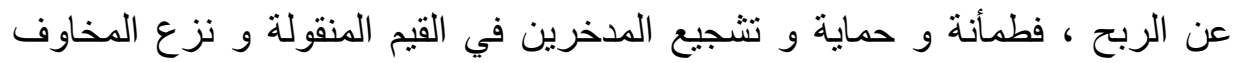

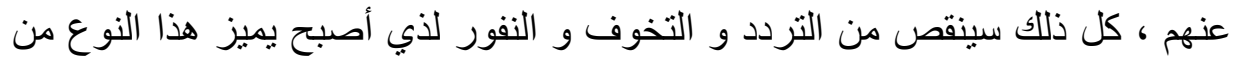
الاستثمار لاسيما في الجزائر.

و في الجزائر فإن إنشاء سوق مالية كان يدخل ضمن مسار الإصلاحات الاقتصادية

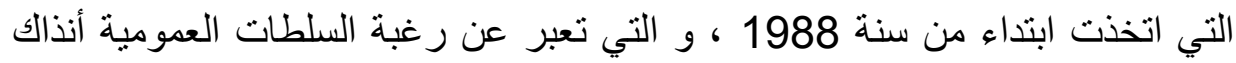

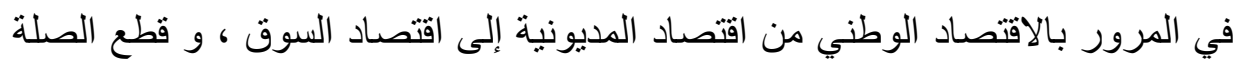

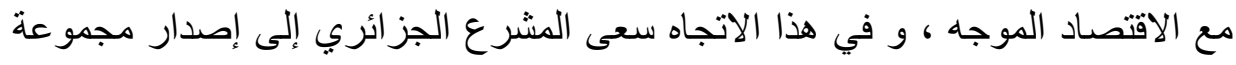

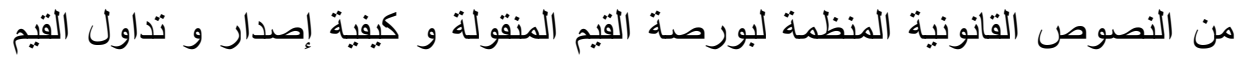

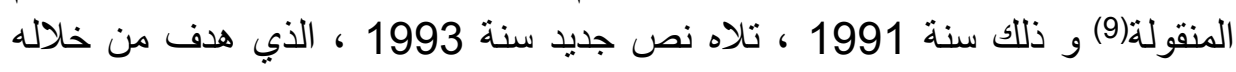

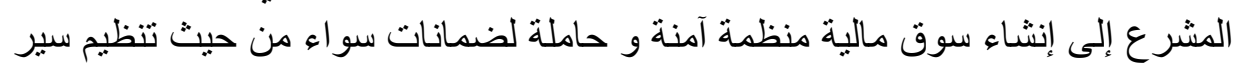

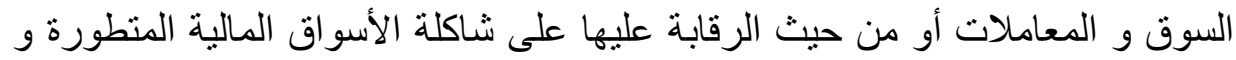
هو المرسوم التشريعي 93-10 المؤرخ في 23 ماي الرفابة علي علي 1993 المتعلق ببورصة القيم 
المنقولة ، و قد تزامن ذللك مع تعديل القانون التجاري بالمرسوم التشريعي 93-08 (10)

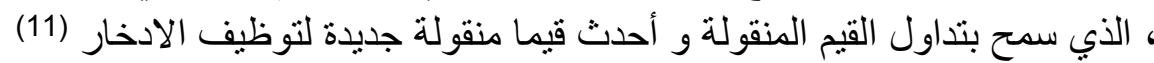
و عزز المشرع الجزائري تدخله في تنظيم السوق المالية سنة 2003 بصدور قانون

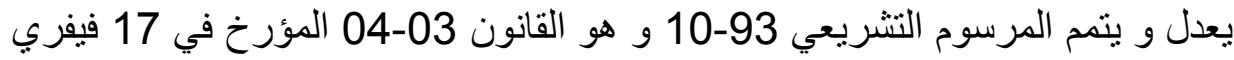
2003 ، و الذي كرس وسائل قانونية جديدة لحماية السوق المالية . لكل ما سبق فإننا نتساءل عن الرقابة التي تمارسها بورصة القيم المنقولة على شركات المساهمة في الجزائر ؟ آلياتها ؟ و مدى فئاع فعاليتها ؟

لمعالجة هذه الإشكالية سنحاول بداية إلقاء الضوء على حارس السوق المالية في

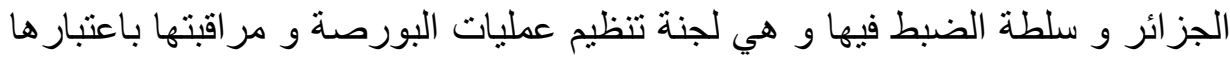
الجهة التي تمارس الرقابة على الهيئات المصدرة ، و لأن سوق الأوراق المالية تقسم من حيث طبيعة السوق و المتعاملين فيها إلى قسمين رئيسين هما : سوق الإصدار

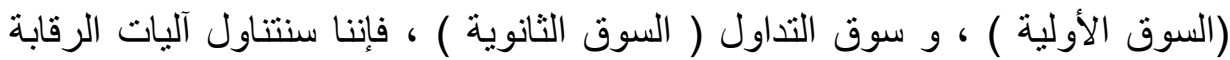
على شركات المساهمة في السوق الأولية ( المطلب الأول ) ، بعدها في السوق الثانوية

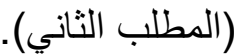

\section{المطلب الأول : الرقابة على شركات المساهمة في سوق الاصدار :}

تعد الرقابة على أسواق المال بصفة عامة و بورصات الأوراق المالية بصفة خاصة ، ذات أهمية كبيرة لحفظ إستقرار السوق و حماية المستثمرين المتعاملين فيه ، فلاشك أن نجاح و ازدهار بورصة الأوراق المالية تحتاج إلى بناء جدار من الثقة و الطمأنينة

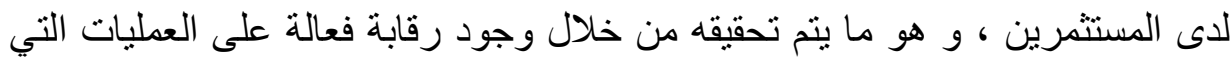

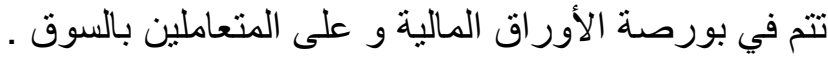
و تهدف الرقابة على بورصة الأوراق المالية إلى التحقق من مطابقة التعاملات التي تتم بالبورصة لأحكام القوانين و اللو ائح المنظمة للسوق، و الحافيه الحيلولة دون قيام المتعاملين

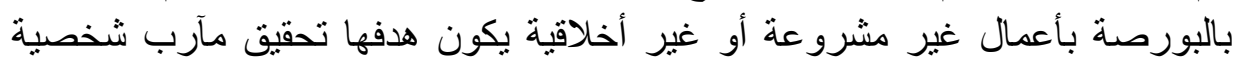

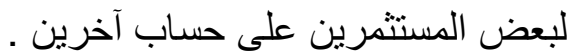

و إضافة لحماية المستثمرين و بناء الثقة في السوق ، فإن الرقابة على سوق المال تهدف لضمان عدالة و فعالية و شفافية في السوق ، و كذا التقليل من المخاطر التي 
و عليه فإن عملية الرقابة على بورصات الأوراق المالية تلعب دورا كبير ا في إزدهار

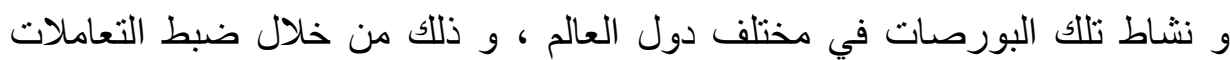
داخل هذه البورصات (12).

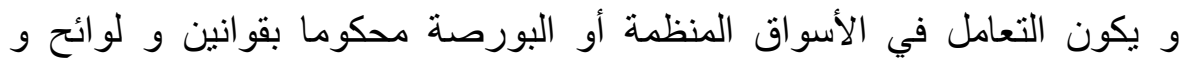
إجر اءات رسمية و تشرف عليها هيئات متخصصة ، و لا يتم التداول إلا على الأسهم و

$$
\text { السندات المدرجة في السوق. }
$$

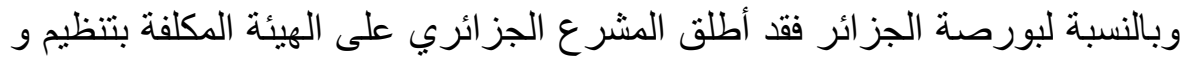

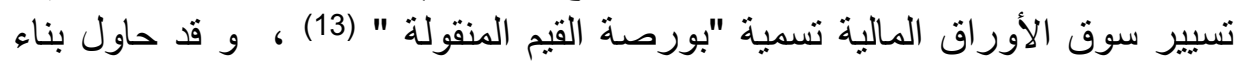

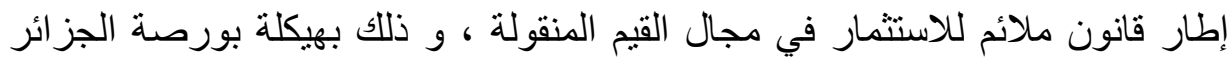

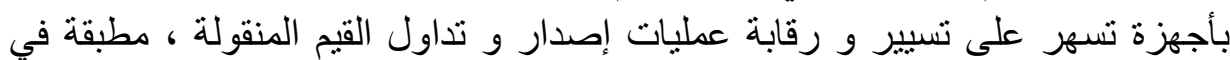
ذلك النصوص التشريعية و التنظيمية المنظمة لهذه العمليات ، و حسب نص ابله المادة 3

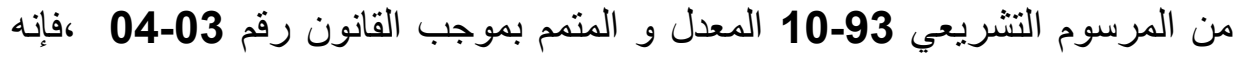

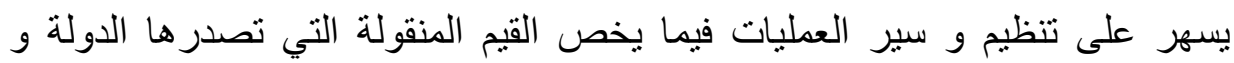
الثركات ذات الأسهم التي تلجا علانية للادخار ثلاث هيئات هي:

- شركة تسيير بورصة القيم المنقولة. ـ لجنة تنظيم عمليات البورصة و مر اقبتها .

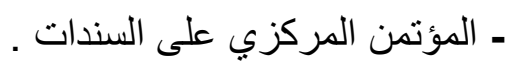

و لأن موضو عنا هو الرقابة على شركات المساهمة المدرجة أسهرها في البورصة ، فإن الهيئة التي تعني موضو عنا بشكل مباشر هي:

ـ لجنة تنظيم عمليات البورصة و مراقبتها : هي من الهيئات والأجهزة الهامة التي وضعها المشرع الجزائري في تركيية بورصة القيم المنقولة، بل وهي أهمها باعنبار ها هاتيا

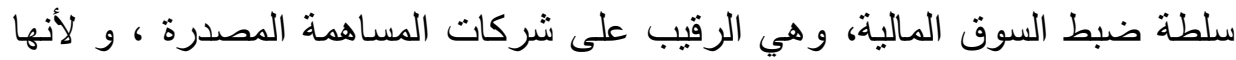

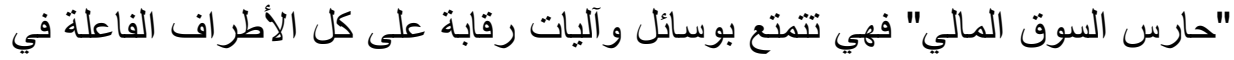

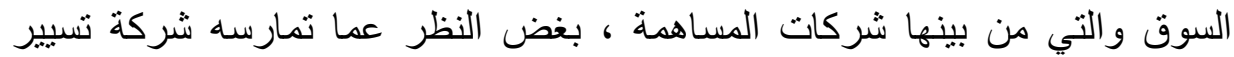
البورصة و المؤتمن المركزي على النيندات كل في مجال وظائفه. 
تعتبر لجنة تنظيم عمليات البورصة ومر اقبتها من بين سلطات الضبط المستقلة

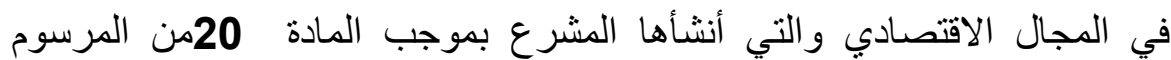

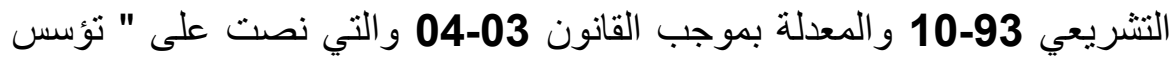
سلطة ضبط مستقلة لتنظيم عمليات البورصة ومر اقبتها ، تتمتع بالثخصية المعنوية

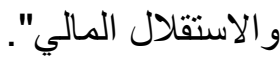

تعد لجنة تنظيم عمليات البورصة ومراقبها أحد أهم الآليات التي اعتمد عليها

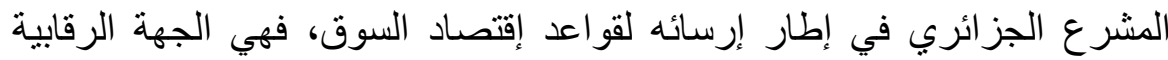

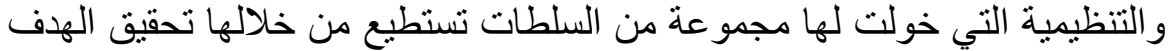
من إنتائها ، والقيام بوظيفتها على أكمل وجه ، و و هي تتمتع بالاستقلالية خاصة

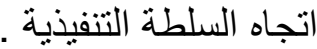

وتهدف لجنة تنظيم عمليات البورصة ومر اقبتها من خلال الصلاحيات المخولة لها

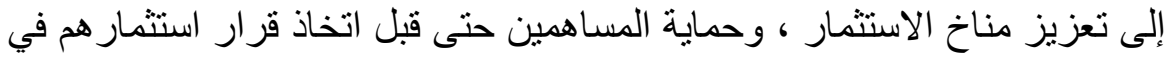

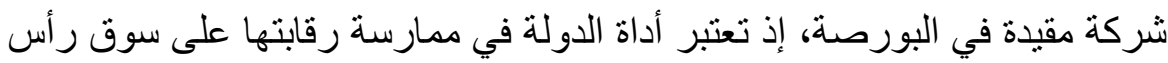

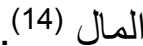

* و عن طبيعتها القانونية تكيّف لجنة تتظيم و مر اقبة عمليات البورصة بكونها سلطة إدارية ضابطة في المجال الاقتصادي تتمتع بالثخصية المعنوية و الاستقلال المالي

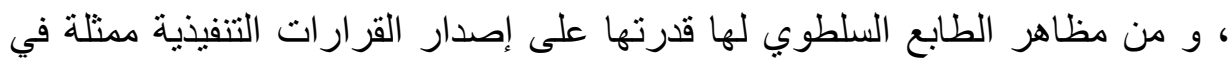
سلطة اصدار النصوص (أنظمة ، تعليمات ، توصيات ) التي تضبط من خلالها

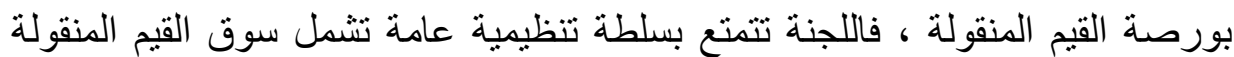

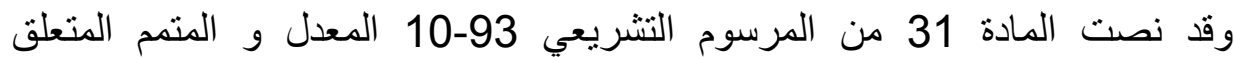
ببورصة القيم المنقولة على المجالات التي يمكن فيها للجنة سن اللوائح .

و إضافة للسلطة التنظيمية العامة فان للجنة البورصة سلطة اصدار قرارات فردية

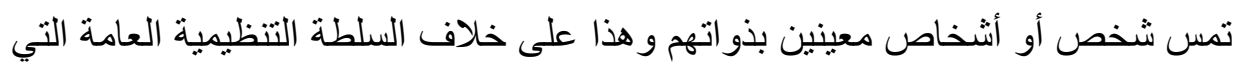

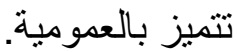
هذا و تخضع اللجنة في ممارسة سلطتها التنظيمية لرقابة كل من السلطة التنفيذية و

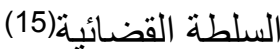

* وعن استقلالية اللجنة فقد وصفت لجنة تنظيم بورصة القيم المنقولة ومراقتتها بالمشرع كونها تتمتع بسلطة تنظيمية تسمح لها بالتشريع في مجال البورصة و و القيم 
المنقولة، وبالثرطي كونها تر اقب وتبحث عن كل المخالفات للنصوص التشريعية و

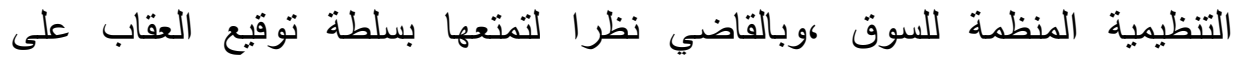
المخالفين(16)، وزودت اللجنة بهذه السلطات لضمان استقلاليتها الوظيفية و عدم تبعيتها للجهاز التشريعي ولا التنفيذي ورودا القضائي في ممارسة مهامها ،إضافة لإنة لاستقلالية عضوية تتمتع بها اللجنة(17) ولانية

* و بالنسبة لاختصاصات و وظائف لجنة تنظيم عمليات البورصة و مر اقبتها فتعتبر

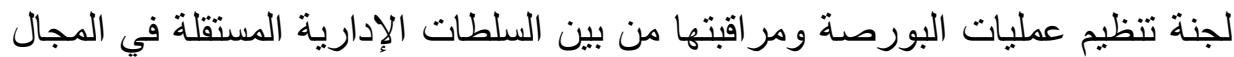
الاقتصادي والتي تتكفل بالسهر على حسن سير البورصة من خلان تونس توفير الثفافية و المساو اة بين المتعاملين داخل السوق.

ولتحقيق أهدافها بتتظيم السوق وحماية الادخار فيه كلفت اللجنة بوظائف ومنحت لها اختصاصات وزودت بسلطات ووسائل للقيام بوظائفها التي يمكن تقسيمها الى لى وظائف واختصاصات تنظيمية و وظائف و اختصاصات رقابية عقابية ،كما لها وظيفة تحكيمية و تـأديبية .

فبالنسبة للوظائف والاختصاصات التنظيمية فقد أقر المشرع للجنة السلطة التنظيمية

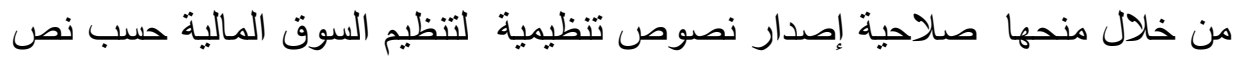

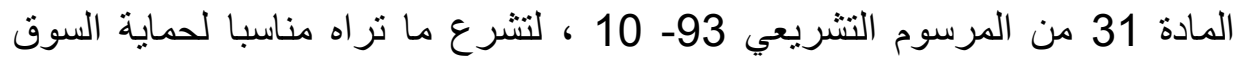

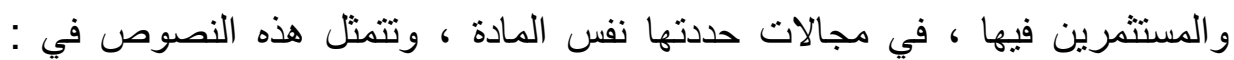

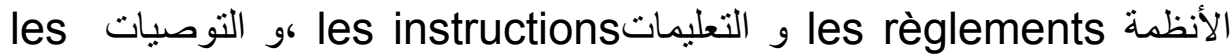
communiqués و الآراء les avis ، المنشورات ال recommandations . les

و تعتبر هذه الامكانية آلية هامة و فعالة للرقابة على السوق و على شركات

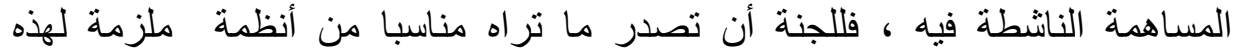

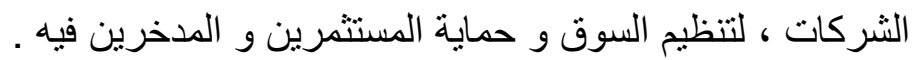

أما فيما يتعلق بالاختصاصات و الوظائف الرقابية فتختص لجنة البورصة بالرقابة

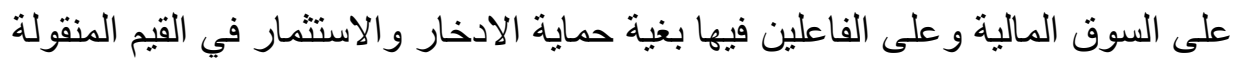
و لا سيما حماية المستثمرين، فهي تمارس رقابة على الثركات المصدرة للقيم المنقولة

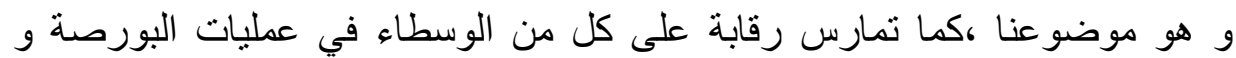
شركة تسيير بورصة القيم المنقولة ، و أخرى على المؤتمن المركزي على على السندات. 
و كان لابد من المرور على النظام القانوني للجنة تنظيم عمليات البورصة و مر اقبتها

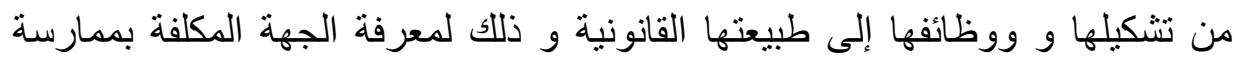

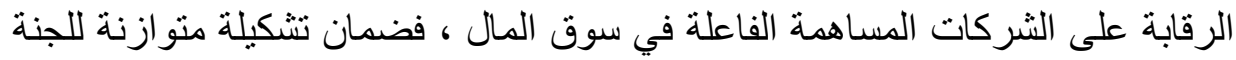

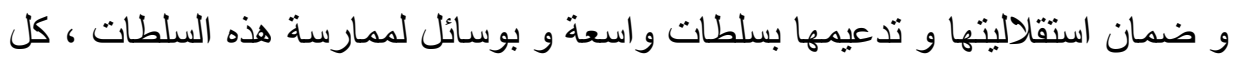

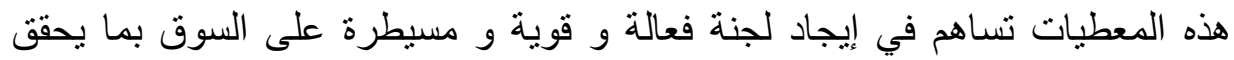
رقابة فعالة على عناصر السوق و التي منها شركات فئه المساهمة .

* و بالرجوع للرقابة على شركات المساهمة في السوق الاولية ، فإن السوق الأولية

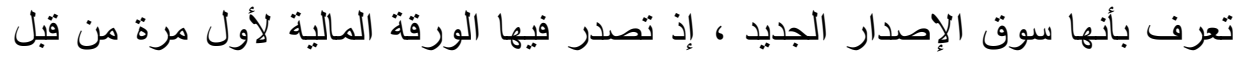

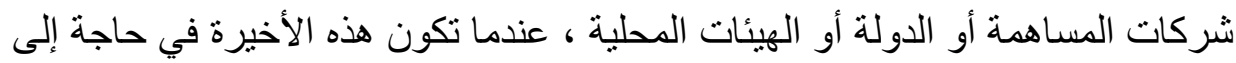

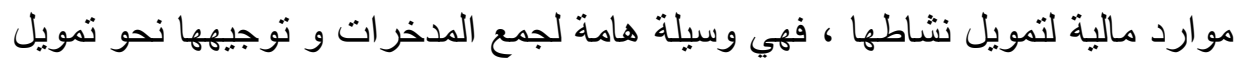

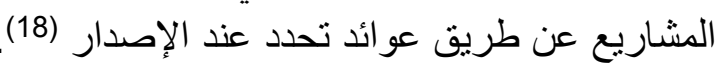

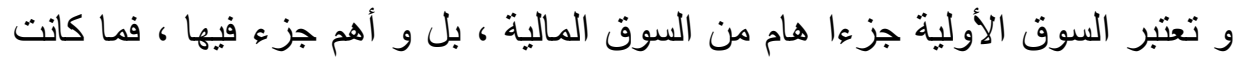

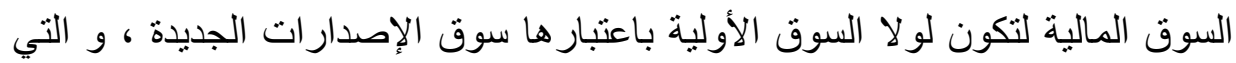

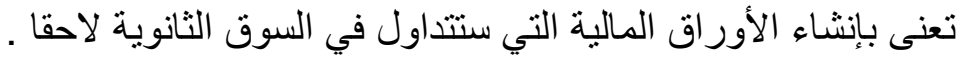

وتطرح شركات المساهمة أسهمها في السوق الاولية في مرحلتين هما : مرحلة

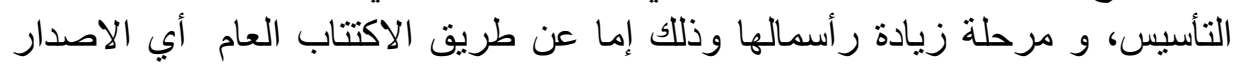

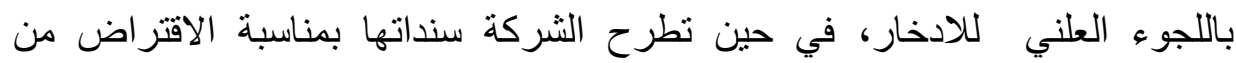
الجمهور .

وفيما يتعلق بالرقابة على شركات المساهمة في سوق الاصدار فإنها تكون اساسا

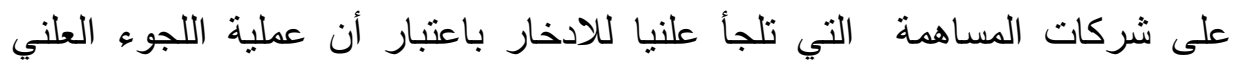

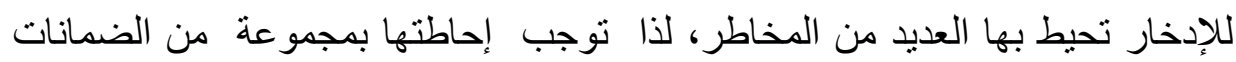

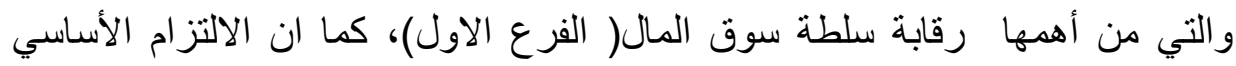

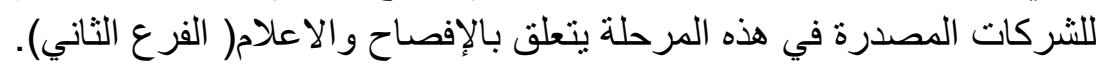

\section{الفرع الاول: اللجوء العلني للادخار وآليات الرقابة عليه :}

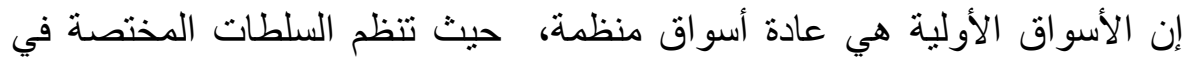

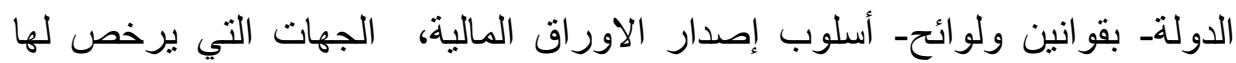

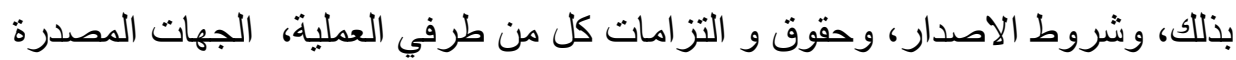

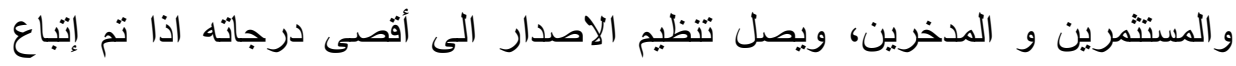


أسلوب الاكتتاب العام أي اللجوء الى الاعوة العلنية للادخار، حيث تحرص السلطات

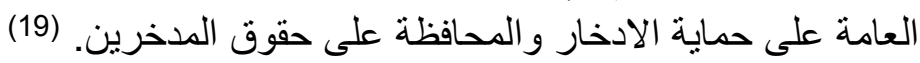

إن الدعوة العلنية للادخار هي وسيلة تم الاعتماد عليها منذ زمن، وتم تكريسها قانونا من أجل تجميع وتحصيل رؤوس الاموال، ولتشجيع الاستثمار في القيم المنقولة فقد حرصت التشريعات على تنظيم ومراقبة عمليات إصدار القيم المنقولة عن طريق

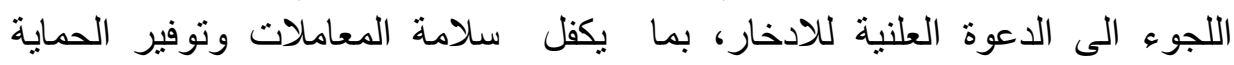

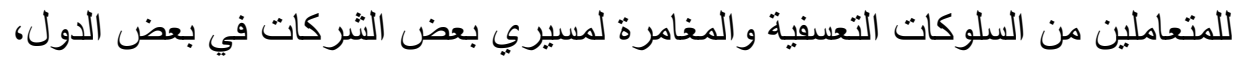
هي التي ادت الى المساس والاضرار بحقوق المدخرين و بالمصلحة الاقتصادية العامة

وبالنسبة للمشرع الجزائري فإنه وفي اطار تنشيط السوق المالية ، فقد أطر عملية

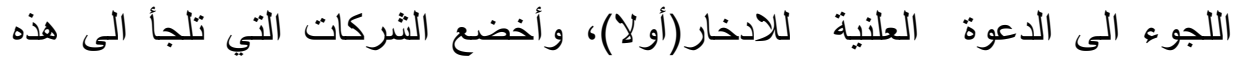

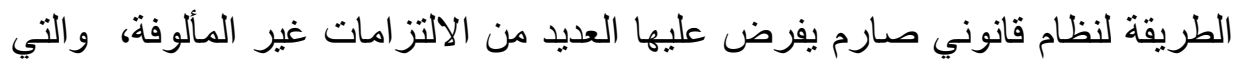
من بينها رقابة لجنة تنظيم عمليات البورصة ومن ومر اقبتها(ثانيا).

\section{أولا: الاطار التشريعي للجوء العلني للادخار:}

نظمت القو اعد العامة لعملية اللجوء العلني للادخار بموجب القانون التجاري، وذلك ألك

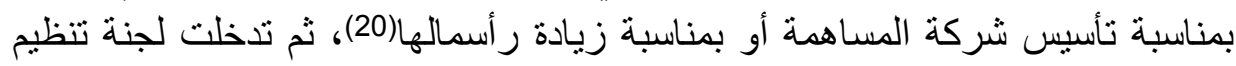
عمليات البورصة ومراقبتها لإضافة اجراءات خاصة لإتمام عملية اللجوء العلني

و قد تم تكريس فكرة الدعوة العلنية للادخار في القانون الجزائري سنة 1993

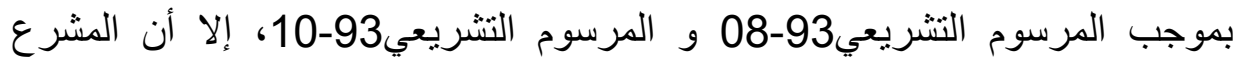

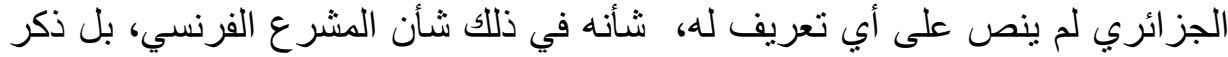

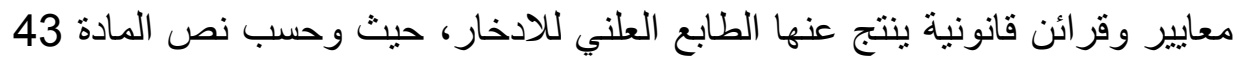

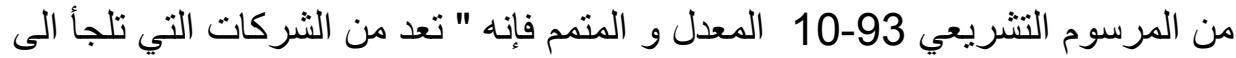

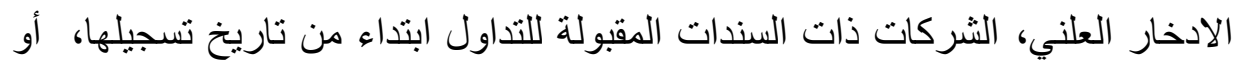
تللك التي تلجأ الى توظيف سنداتها مهما كان نوعها إما الى البنوك أو أو المؤسسات

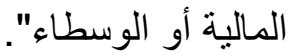

و قد أتت لجنة تنظيم عمليات البورصة ومر اقبتها بمعايير اخرى عن تلك المحددة

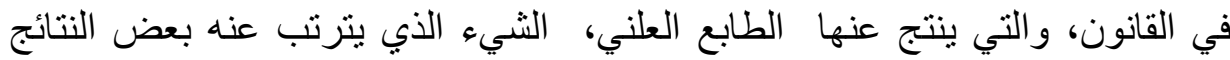


الهامة، مادام أنه يكفي أن يتوافر إحداها لإخضاع الهيئة المصدرة لنظام قانوني صارم و التز امات محددة.

فحسب نص المادة الثانية من نظام لجنة ت ع ب رقم 96- 02 (21)، فان الطابع

العلني للادخار ينتج من:

ـ توظيف الاصول المالية بحجم يتعدى دائرة محدودة من الاشخاص، الذي يفترض حدوثة عندما يعني أكثر من 100 شخص.

- قبول القيم المنقولة للتداول في بورصة القيم المنقولة.

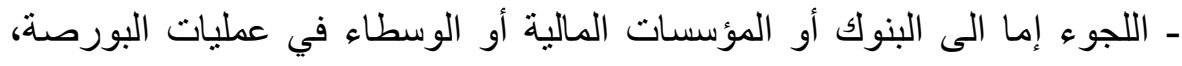
و إما إلى أساليب الاشهار العادي وإما إلى السعي المصفقي".

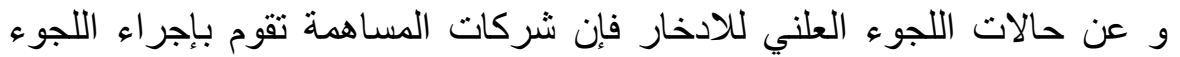

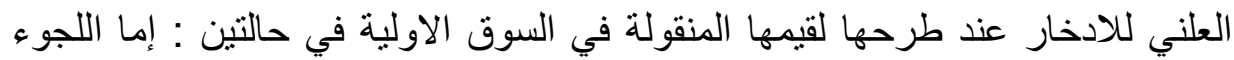

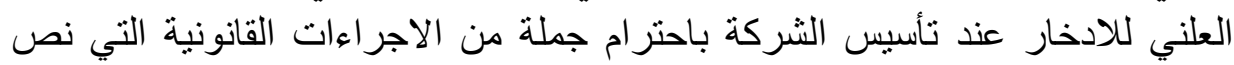

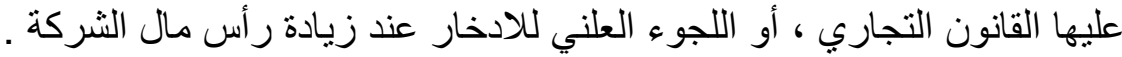

و بالرغم من الثروط و الضمانات التي أوردها المشرع و التي أحاط بها عملية

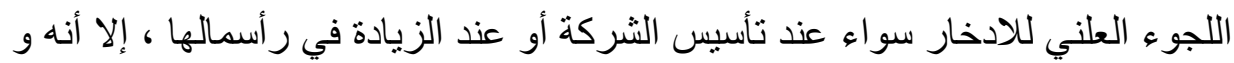

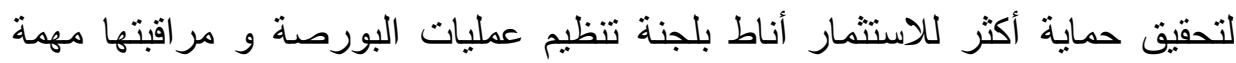
الرقابة على الثركات التي تلجأ علنيا للادخار.

ثانيا: رقابة لجنة البورصة على عمليات اللجوء العلني للادخار ( الإصدار ):

يعتبر أمن و سلامة الادخار من أولى انشغالات المشرع لضمان حماية حقيقية

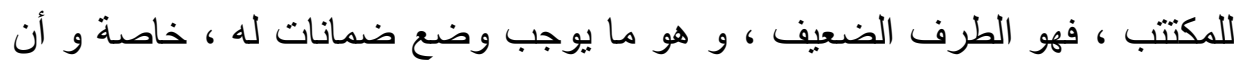

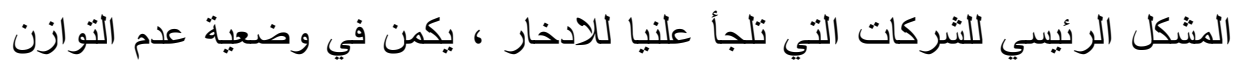

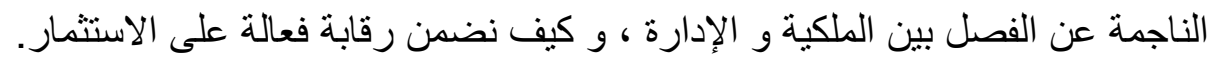

و قد سمح قانون السوق المالية بالجزائر للجنة تنظيم عمليات البورصة و مر اقبتها

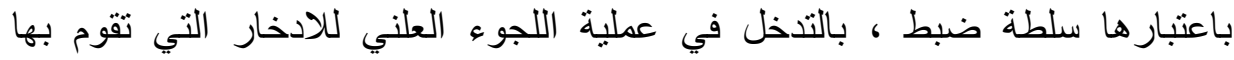

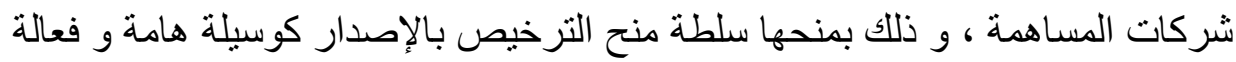
لممارسة الرقابة على شركات المساهمة في سوق الإصدار. 


\section{I- الجهة المصدرة للترخيص:}

سعت كل القوانين رغم اختلافها إلى توفير حماية خاصة للمدخر الملتمس منه

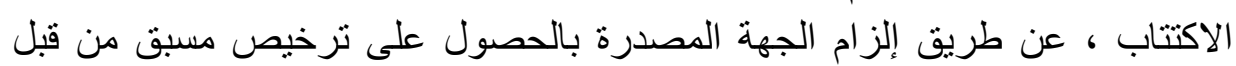
الهيئات المختصة ، قبل طرح القيم المنقولة على الجمهور للاكتتاب ، و و قد سلد سلك

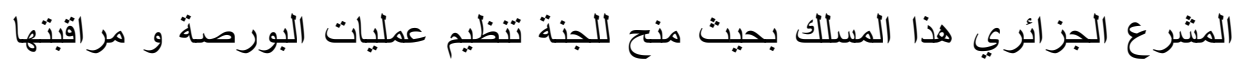

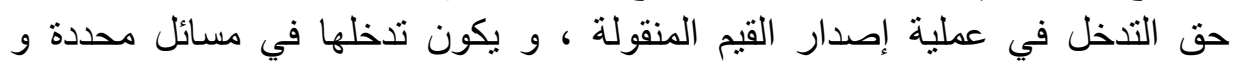
بكيفيات معينة.

\section{|I- |l - كيفيات و موضوع الترخيص:}

يكون تدخل لجنة تنظيم و مر اقبة عمليات البورصة في عملية إصدار القيم المنقولة من

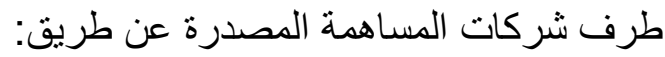

1- تحديد حجم الإصدار: تختص بتحديد حجم الإصدار الهيئة المكلفة بالترخيص به(22)

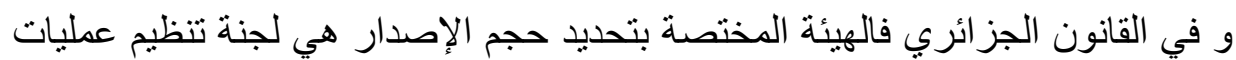

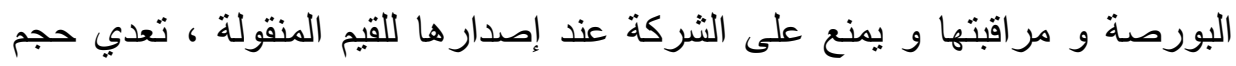

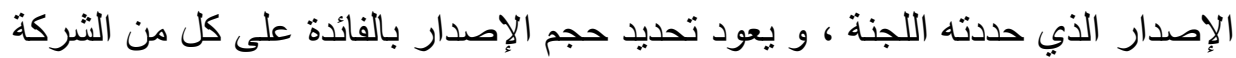

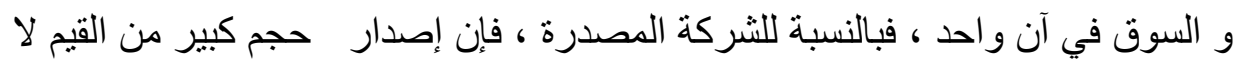
يخدم مصالحها بالضرورة ، فكلما ارتفع حجم الإصدار زاد فاد تغير تركيبة المساهمين

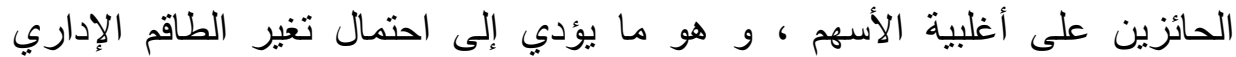
للشركة(23).

أما بالنسبة للسوق يهدف التحديد إلى عدم إغر اقها بإصدارات جديدة و كثيرة ، ما

$$
\text { قد يؤثر على القيمة السوقية للورقة. }
$$

و عليه فإن الإصدار يتم في الحدود التي تمتصها السوق بالنسبة للحد الأقصى

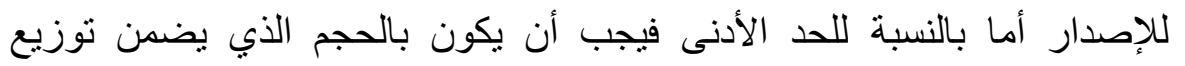
الأوراق المصدرة بشكل عريض على المستثمرين.

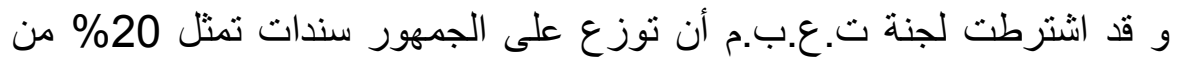

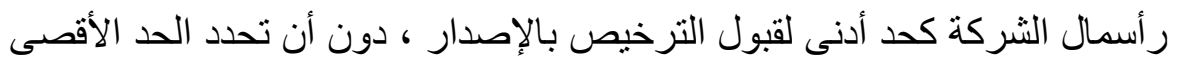
، الذي تركته للجمعية العامة للمساهمين(24). 2- التأثير على إعلام جمهور المستثمرين: 
تلعب المعلومة دورا هاما في عالم أهم ما يتميز به هو تتوع وسائل الاتصالات و والهات

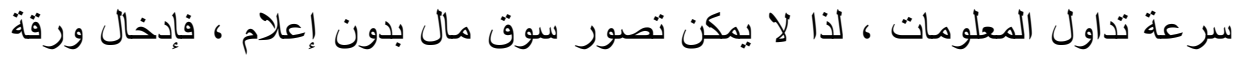

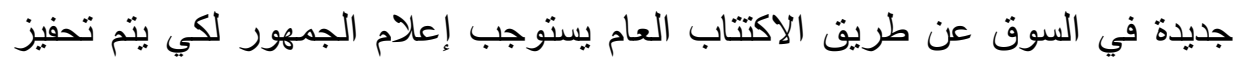
المدخرين و المستثمرين و تهيئتهم لإنجاح هذا الاكتتاب ،و كذا الحال بالنسبة لزيادة رأس المال ، فالإعلام يلعب دورا هاما و حيويا بالنسبة لسوق الإن المال.

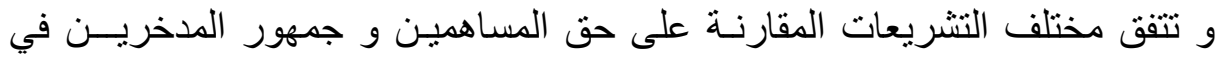

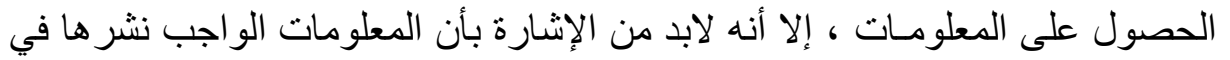
سوق الإصدار تختلف عن المعلومات الواجب الإفصاح عنها في سوق الإنداول.

إن هنالك ارتباط وثيق بين واجب الإعلام و لجوء الثركة للاكتتاب عن طريق

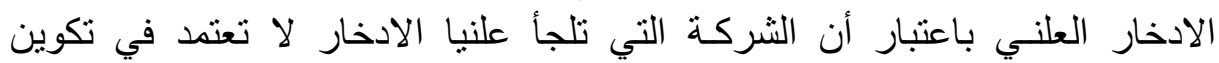

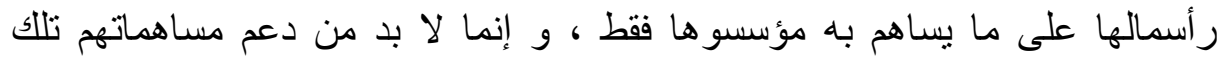

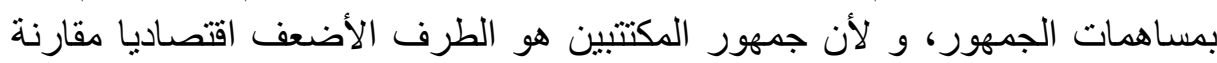

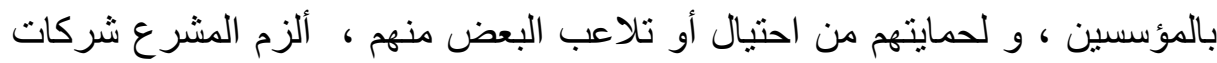

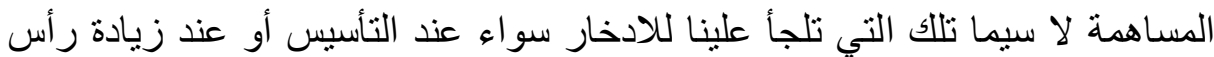

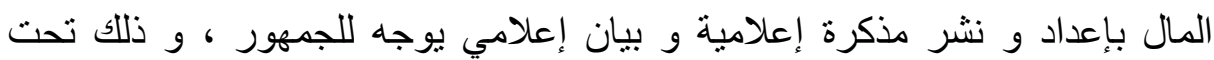
طائلة عدم الحصول على ترخيص بالإصدار.

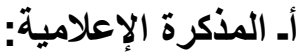

أ-1 مضمون المذكرة : في سبيل تزويد المكتتبين بإعلام كافي حول الثركة

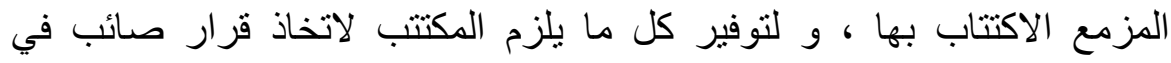

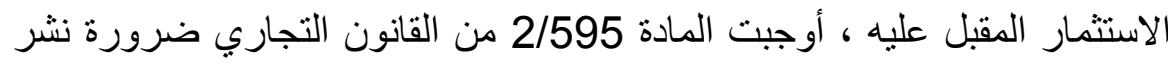
المؤسسين تحت مسؤوليتهم إعلانا حسب الثروط المادئ المحددة عن طريق التنظيم ، و و

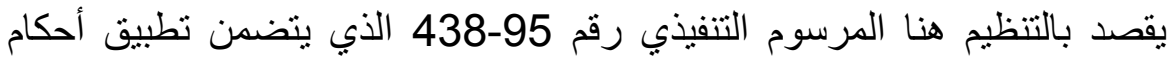
القانون التجاري المتعلقة بشركات المساهمة و التجمعات ، و و الذي جاء في في المادة

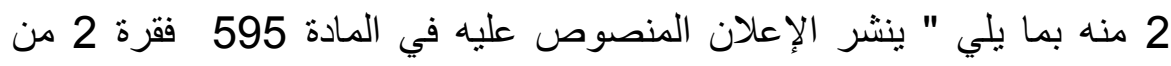
القانون التجاري في النشرة الرسمية للإعلانات القانونية قبل الثرنية الثروع في في عمليات

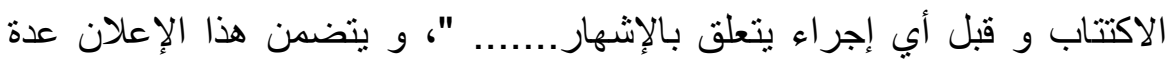

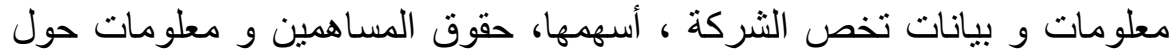


و أخيرا يوقّع المؤسسون على الإعلان الذي يذكرون فيه إما ألقابهم أو أسماءهم

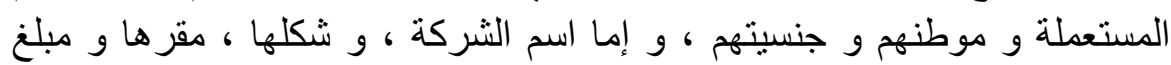
رأسمالها.

و تضيف الفقرة الثالثة من المادة 595 أنه و في حالة عدم احتر ام الإجراءات التي التي ذكر ها القانون فإنه لا يقبل أي اكتتاب .

و لأن الثركات التي تلجأ علينا للادخار هي من الأطراف الفاعلة في السوق

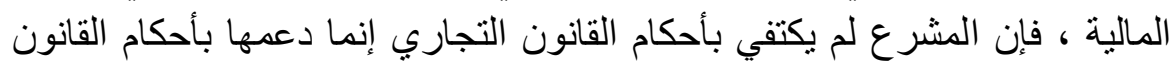

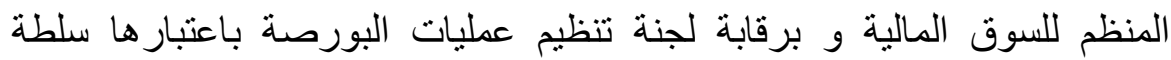

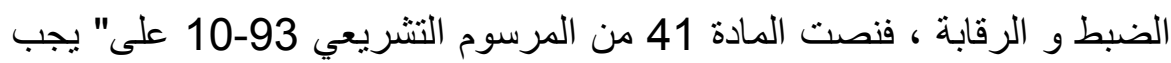

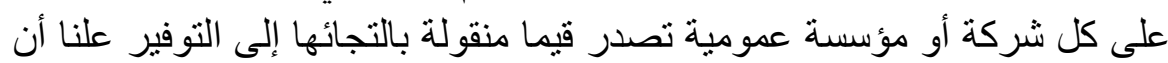

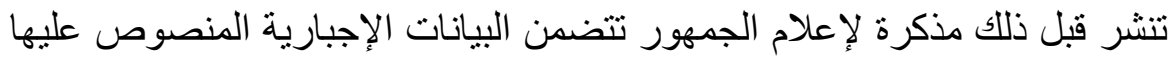
في القانون التجاري ، كما يمكن للجنة أن تطلب أي معلومات أخرى أخرى تتعلق بتنظيم

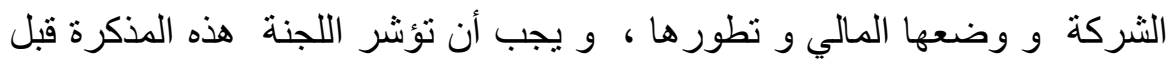

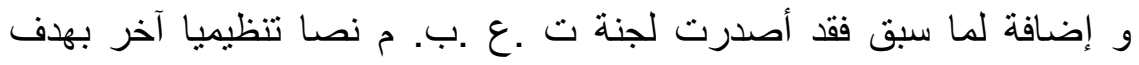

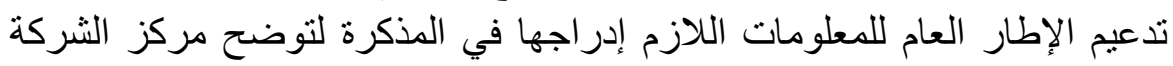

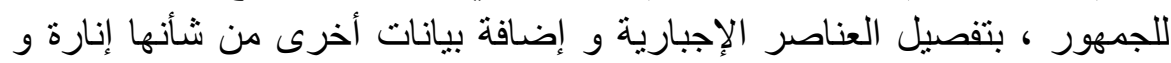
إرشاد قرار الثخص المقدم على الاكتتاب.

فبموجب تعليمة اللجنة رقم 97-0302-02-96 المتضمنة تطبيق النظام

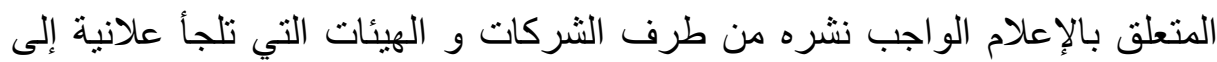

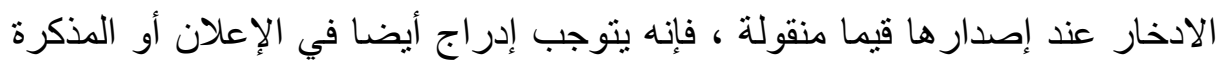

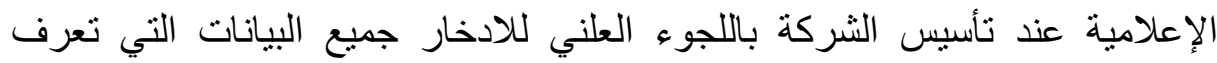

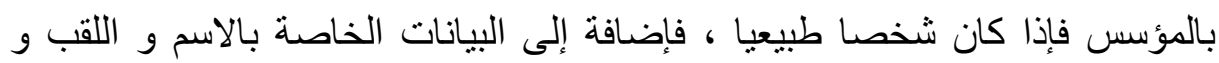

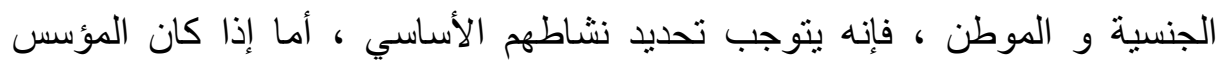

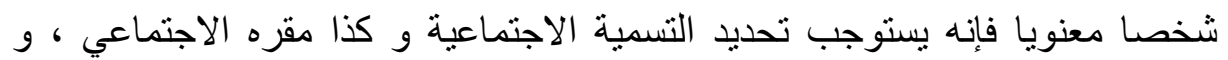

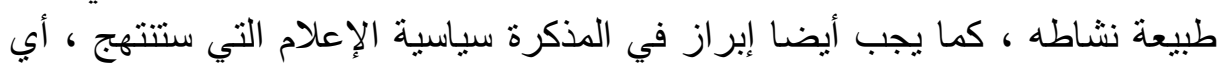

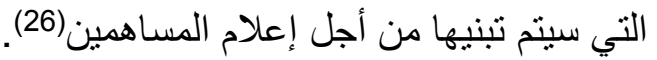


و من أجل إفادة الثخص المدعو للاكتتاب بجميع المعلومات التي تهمه ، فإن هذا

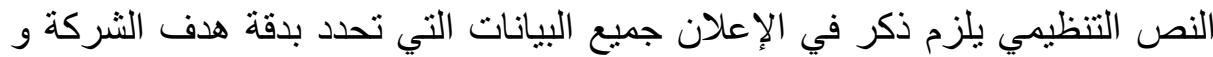

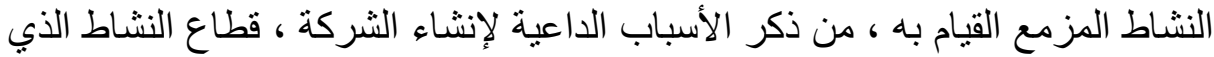
تتذخل فيه من حيث عرض أو التعريف بالقطاع و آفاقه(27).

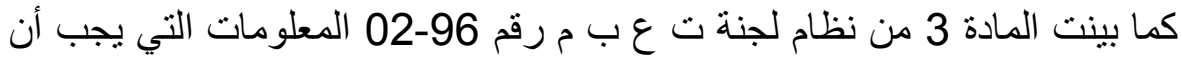
تتضمنها المذكرة الاعلامية بقولها" علاوة على العناصر الإجبارية المنصوص علئه

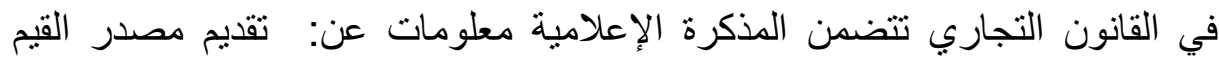
المنقولة ، وضعيته المالية ، تطور نشاطه ، موضوع العملية المزمع إنجاز ها و و

و في إطار مهمة تنظيم سوق القيم المنقولة و السهر على حماية الادخار و الرقابة عليه

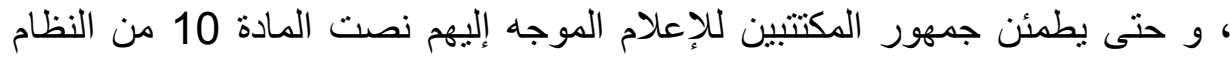

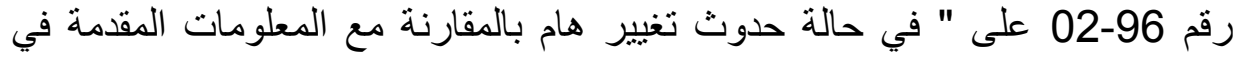
المذكرة الإعلامية ، يجب إدخال تعديل على المذكرة الإعلامية و البيان".

بـ نشر المذكرة: توضع المذكرة الإعلامية و البيان الإعلامي الذي سيتم الاشارة اليه

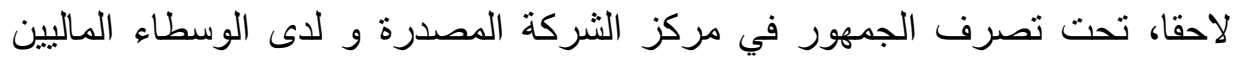

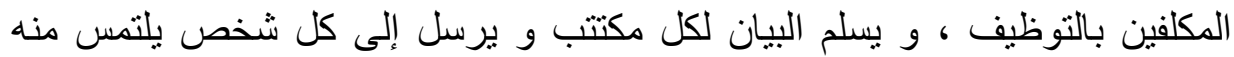

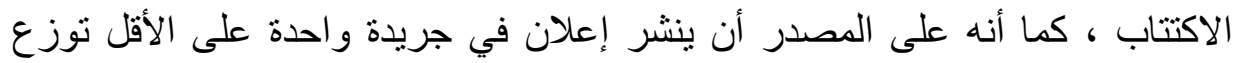

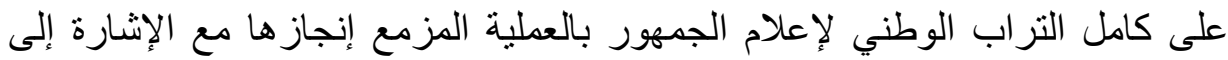
رقم تأثيرة المذكرة الإعلامية (28)

أ-2-التأثشير على المذكرة: تتولى لجنة ت. ع .ب. م حماية المدخر عن طريق توفيرها

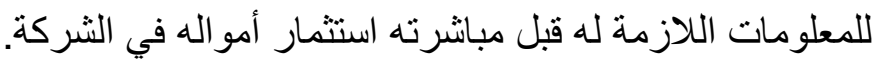

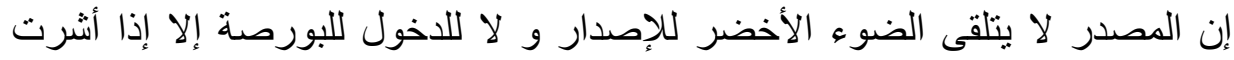
اللجنة على المعلومات التي أدلى بها للجمهور و التي تتضمنها المذكرة الإعلامية.

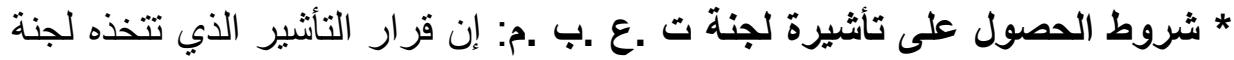

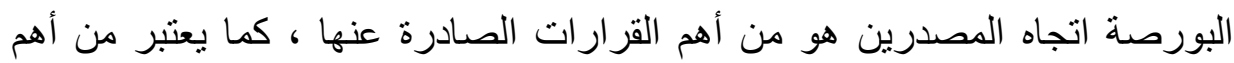

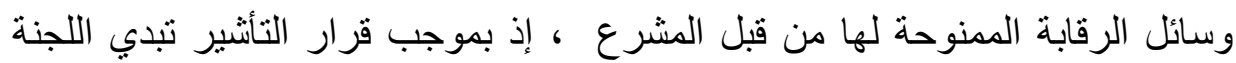

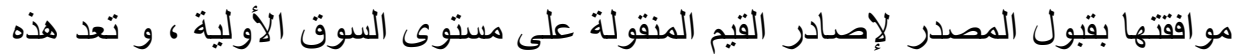

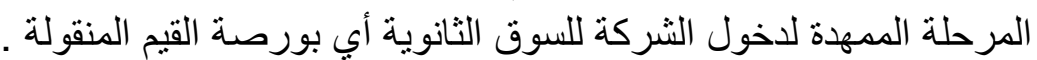


و يعد أول شرط لابد أن تحترمه الثركة المصدرة للقيم المنقولة من أجل الحصول

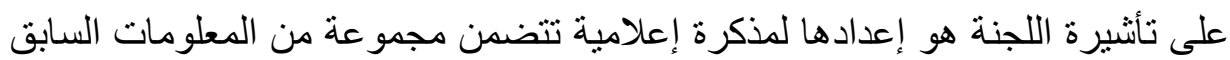

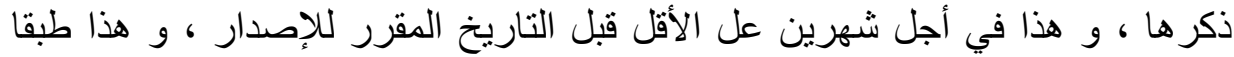
للمادة 4 من نظام اللجنة رقم

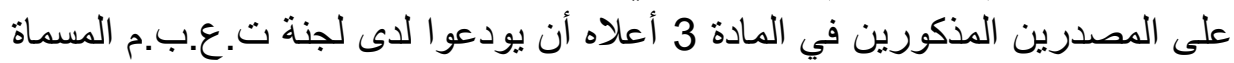

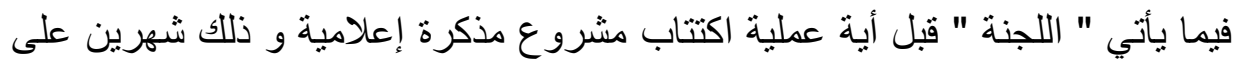

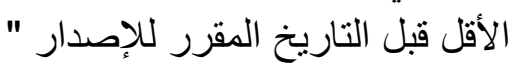

و إضافة للوثائق التي تودعها الثركات المصدرة للقيم المنقولة لاى اللجنة و المرفقة

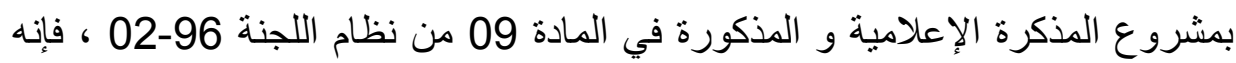

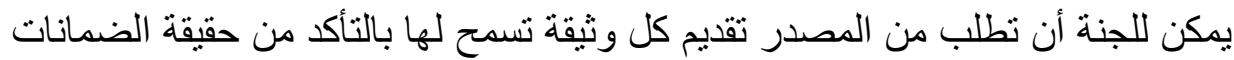

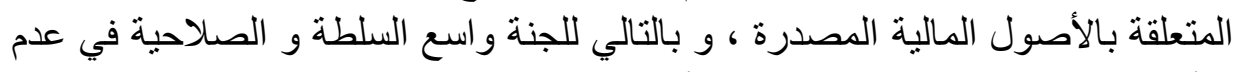
التأثير على المذكرة الاعلامية حتى تتأكد من المعلومات الموجهة لجمهية لجهور المدخرين. و نأكيدا لما سبق فقد نصت المادة 05 من نظام اللجنة رقم 96-02 على " يمكن

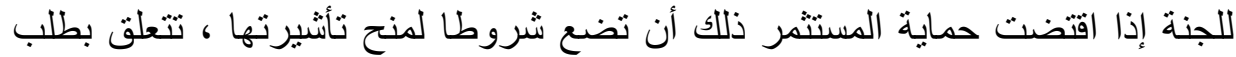

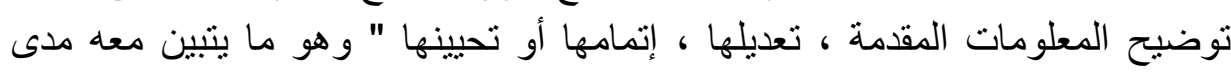

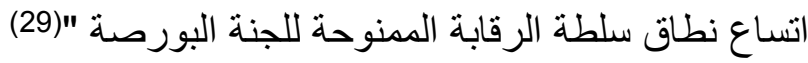
و قد تم تعديل و إتمام نظام لجنة البورصة رقم 96-02 المتعلق بالإعلام الواجب نشره

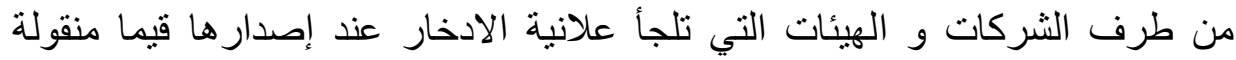

بموجب النظام رقم

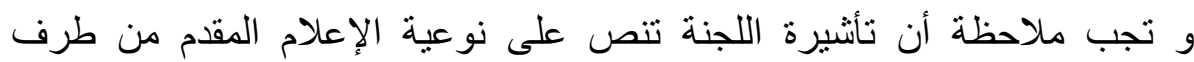

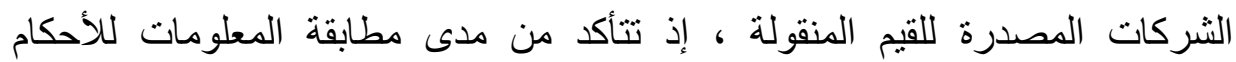

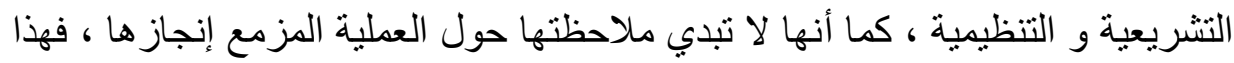

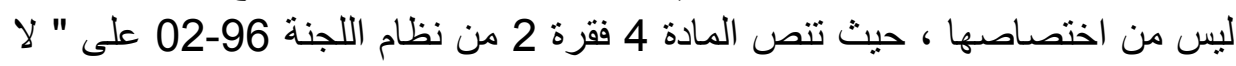

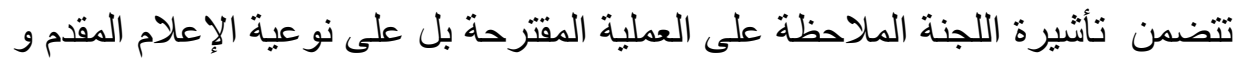

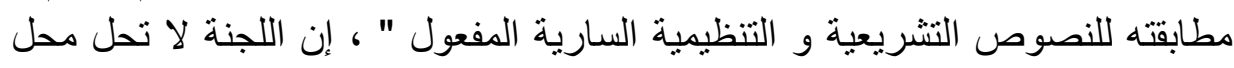
المدخر في اتخاذ قرار الاستثمار. "(31)

و بمنح اللجنة التأشيرة للشركة تكون هذه الأخيرة مؤهلة لطرح قيمها للاكتتاب فيها

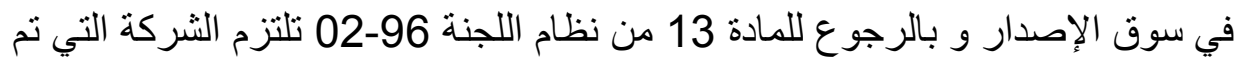


قبولها في السوق الأولية بنشر إعلان في جريدة واحدة على الأقل نوزع في كامل

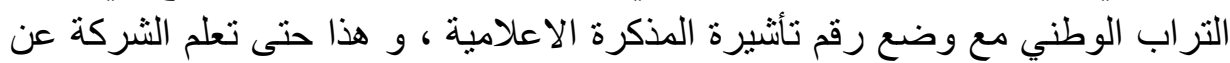

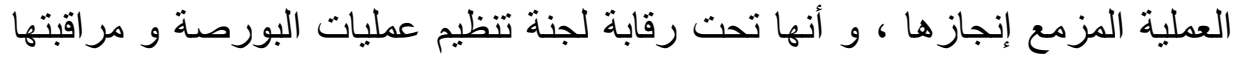
لخلق نوع من الطمأنينة لدى المستثمرين.

\section{أ-3- رفض التأثير على المذكرة الإعلامية:}

تحرص لجنة ت ع ب م على أن تكون عملية الإصدار سليمة حتى تكون العملية

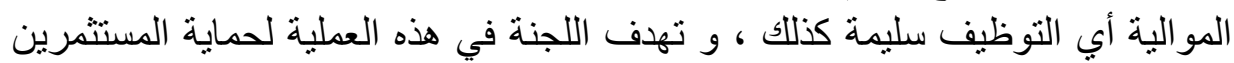
من سوء الإفصاح أو عدمه الذي يمكن أن ترتكبه الثركة في حقهم. و عليه فإنه للجنة أن ترفض التأثير على المذكرة الإعلامية إذا رأت أن الثركة غير مؤ هلة لذلك ، و لأسباب ذكرنها المادة 6 من نظام اللجنة 96-02-06 ، و و هي: " .. - إذا كانت المذكرة الاعلامية غير مطابقة لأنظمة اللجنة و تعليماتها. - إذا كانت المذكرة غير مرفقة بالوثائق المنصوص عليها في أنظمة اللجنة. ـ إذا كانت المذكرة غير مكتملة أو غبر صحيحة فيما يخص بعض النقاط ، أو إذا أهملت ذكر وقائع من اللازم الإشارة إليها في المذكرة. ـ إذا كانت الطلبات الخاصة بتعديلات المذكرة المبلغة من طرف اللجنة غير مرضية. ـ إذا كانت حماية المدخر تقتضي ذلك... ".

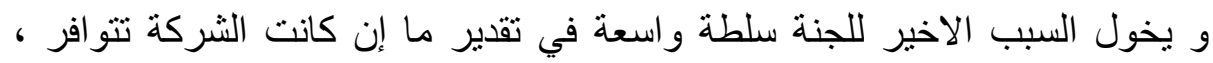

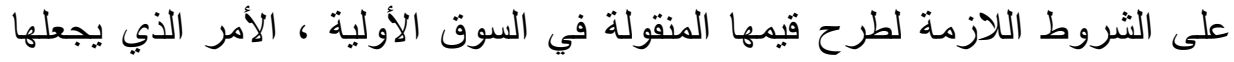
وصية على المدخر في تقرير الحماية له ، بممارسة رقابة لطعة على الثركة.

و تتص الفقرة الأخيرة من المادة 6 المذكورة أعلاه على " ... و في جميع الحالات

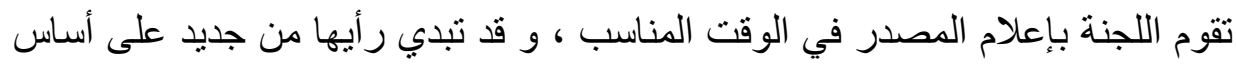

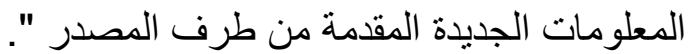

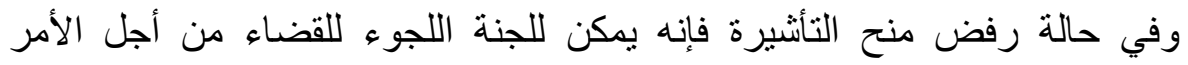
بتوقيف الاكتنابات و الدفوعات وبصفة عامة إلغاء العمليات المتخذة بدون الحصول

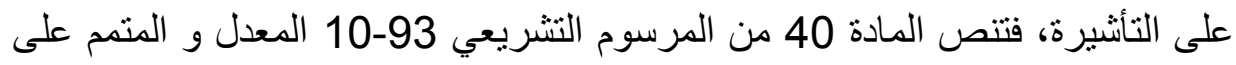


أنه يمكن للجهات القضائية المختصة بناءا على طلب من رئيس لجنة ت.ع.ع.ب.م إصدار

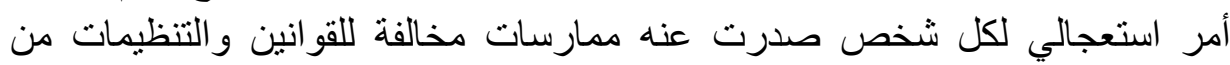

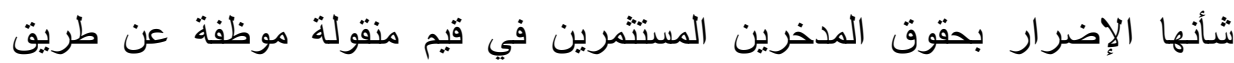
المساهمة العامة بالكف عن هذه الممارسات ووضع المع حد للمخالفة أو إبطال آثار ها.

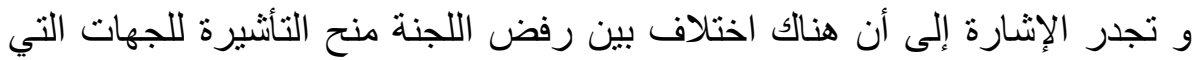

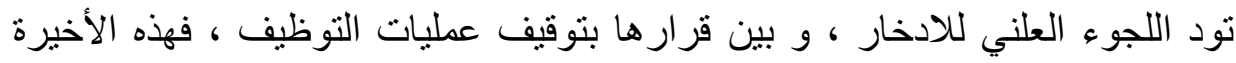

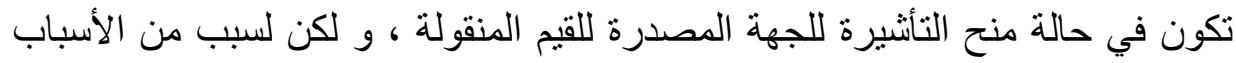
توقف عملية التوظيف ، و قد حددت المادة 19 من نظام اللجنة 96-02 الحالات التي التي

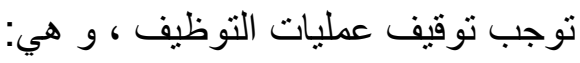
- إذا اعتبرت بأن مصلحة المدخرين تقتضي ذلك. ـ إذا لم يحترم المصدر أنظمة اللجنة و تعليماتها.

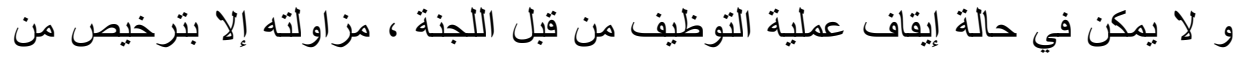

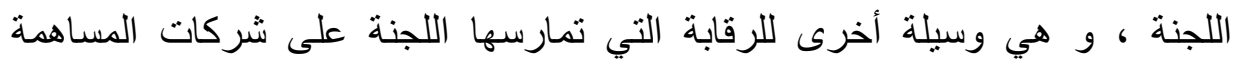
المصدرة للقيم المنقولة .

و دعما لإعلام المستثرين فإنه و إضافة للمذكرة الإعلامية فإن الثركات المصدرة ملزمة بنشر بيان إعلامي.

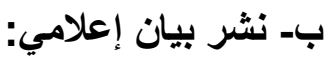
علاوة عن المذكرة الإعلامية فإن شركات المساهمة التي تلجأ علينا للادخار تقوم بطبع بيان إعلامي و نشره.

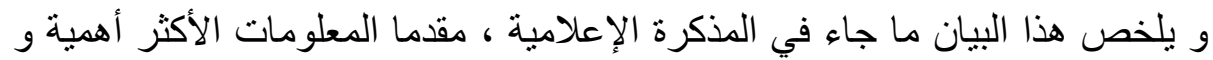

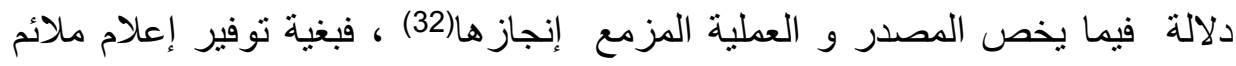

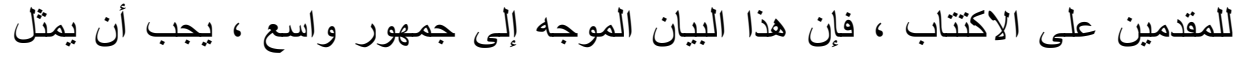
وثثقة واضحة و أكثر دلالة ، أين تدرج فيه أهم المعلومات التيه التي تهم جمهور المكتتبين ،

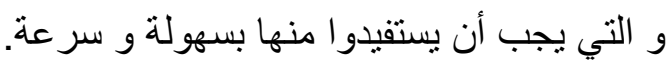

و لا يشرع الاكتتاب العام إلا بعد إتمام كافة إتمام كافة الإجراءات التمهيدية السالفة

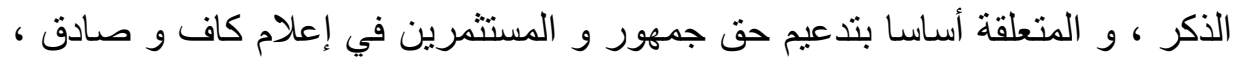


و لأجل ذلك تتدخل لجنة البورصة(33) لكن حرصها على توفير الإعلام و الإفصاح ، لا يتوقف على ما سبق ذكره.

\section{الفرع الثاني: إلتزام الثركات المصدرة بالإفصاح:}

إن أهم وسائل الرقابة الممنوحة للجنة تنظيم عمليات البورصة و مر اقبتها على القى

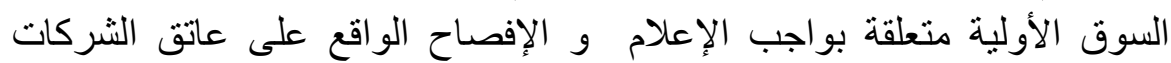
المصدرة للقيم المنقولة ، و باقي أنواع الاعلة المصدرين.

إن القيم المنقولة تمنح لحاملها السلطة و المال ، فيمكن له بموجبها أن يملي

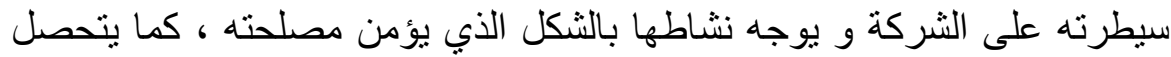
على أمو ال متأتية من الأرباح التي تحققها الثركة من نشاطاتها المختلفة.

لكن المدخر عندما يستثمر ادخاره في القيم المنقولة ، فإنه لا يضمن بصفة مطلقة و أكيدة أنه سيحقق أرباحا ، لكن بالعكس يمكن أن تلحق به خسائر و يتحمل فئل عو اقبها.

و على ذلك فإن استثمار الادخار في القيم المنقولة يجعل صاحبه معرضا إلى خطر

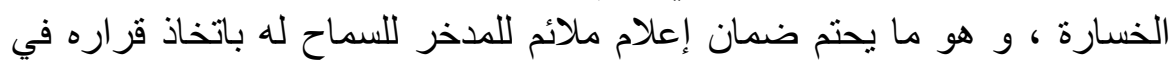

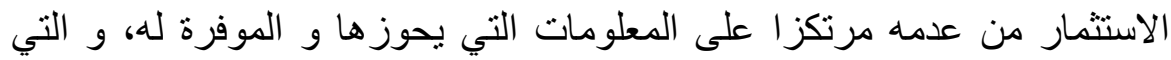

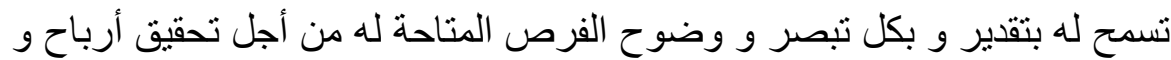

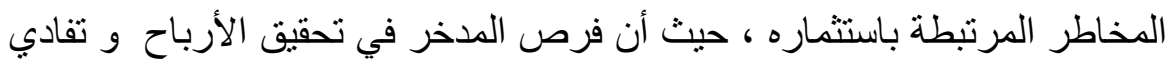

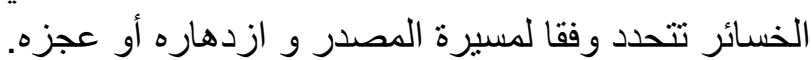

يشكل مبدأ الإفصاح و الثفافية أهمية كبيرة للمتعاملين في القيم المنقولة خاصة

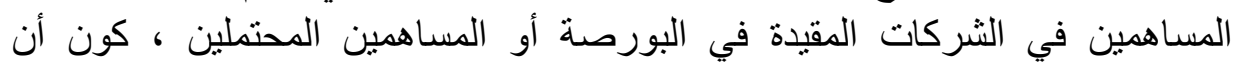

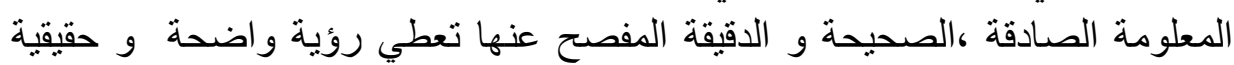
عن طبيعة المركز المالي للجهة المصدرة.

لكل ما سبق و لتحقيق المساواة أمام المعلومة ، و تعزيزا لتقة في الاستثمار في

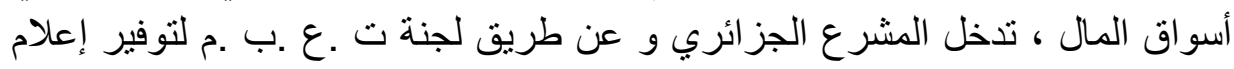

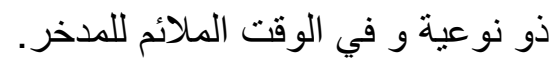


و تعمل اللجنة على توفير المعلومة في سوق رأس المال سواء السوق الأولية عند

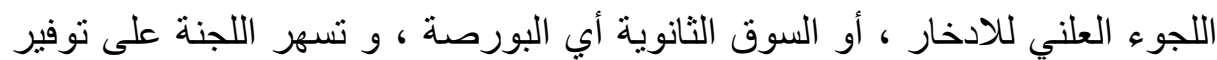

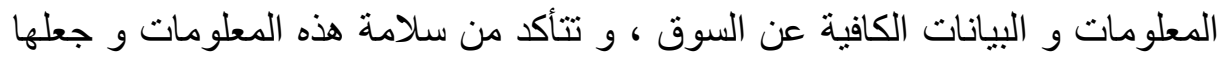

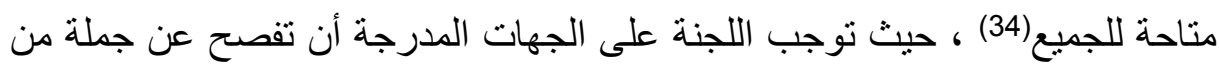

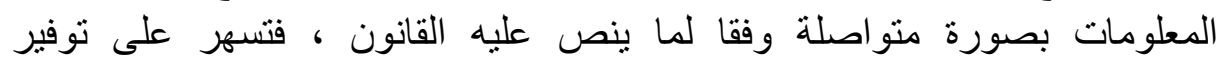

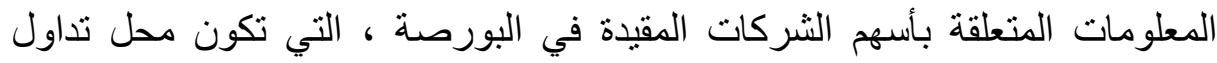

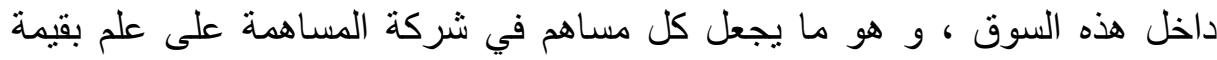

$$
\text { السهم السوقية. }
$$

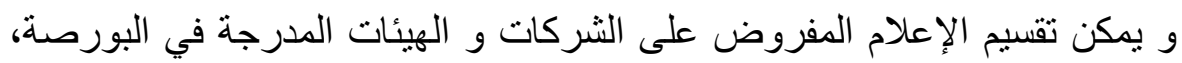

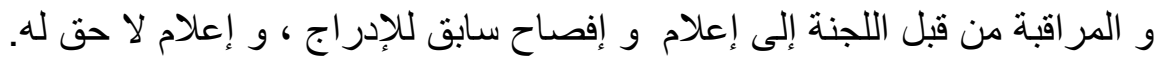

أولا: الإعلام السابق.

بالنسبة للإفصاح السابق فقد ألزمت لجنة تنظيم عمليات البورصة و مراقبتها كل شركة تلجأ علنيا للادخار بأن تفصح عن مجموعة من المعلومات التي تظهر نشات نشاط

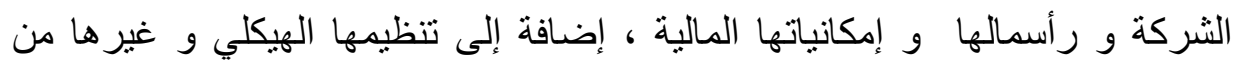
المعلومات ، و ذلك تحت طائلة عدم تمكنها من طر ح أسهمها في السوق الأولية.

و قد سبق و أن فصلنا في التقسيم السابق ،الأحكام التشريعية و التنظيمية المتعلقة بالإفصاح السابق أب في السوق الأولية و المتعلق باللجو ألعاب العلني للادخار.

\section{ثانيا: الإعلام اللاحق}

بعد أن يتم قبول إدر اج القيم المنقولة في البورصة ، تنتقل الثركة المصدرة لمرحلة

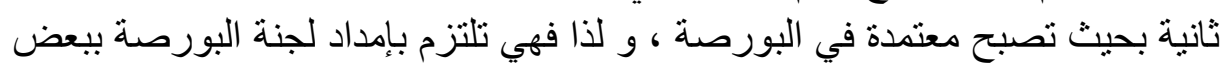

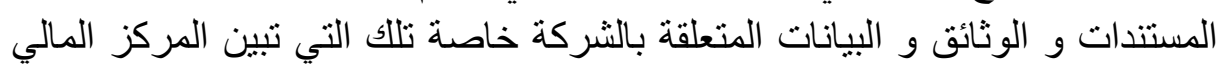

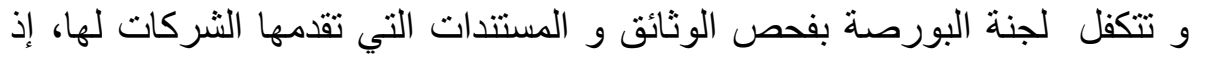
تتأكد من أن المعلومات المدرجة في هذه المستندات صحيحة و كافية ، و بذللك تهنم

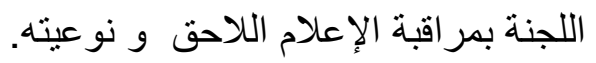


و حسب أحكام المادة 35 من المرسوم التشريعي 93-10 المعدل و المتم: " تتأكد

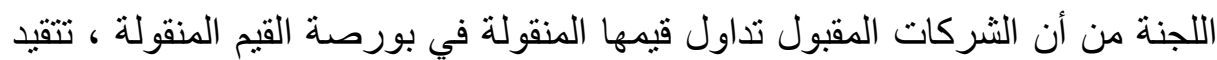

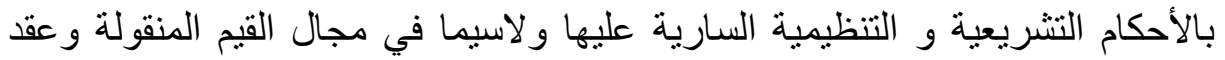

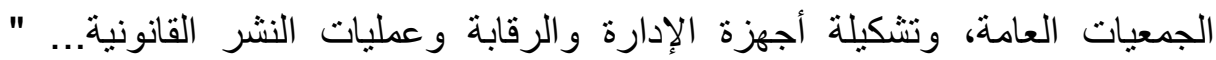

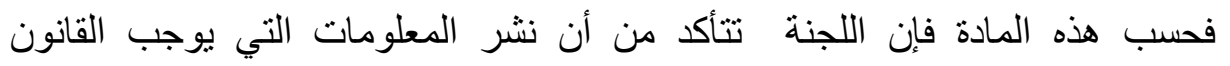

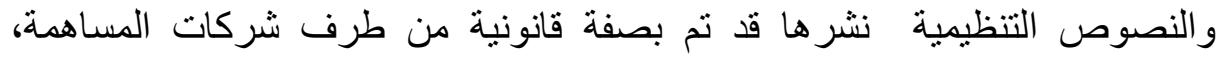

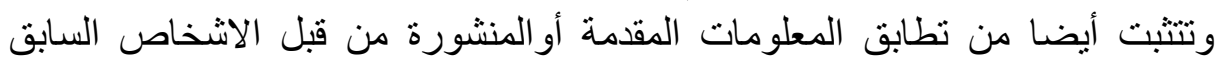
ذكر هم، للمقتضيات التشريعية والتنظيمية.

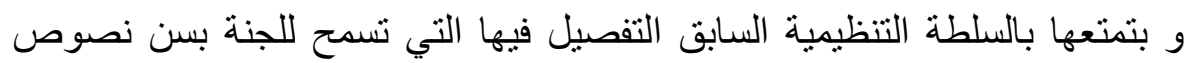

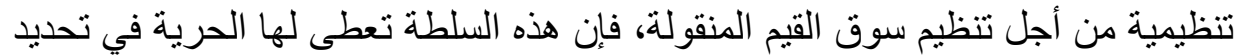

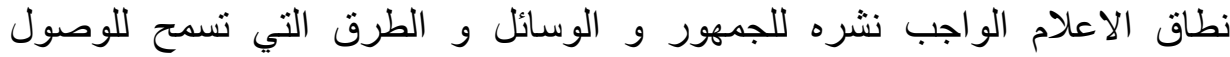

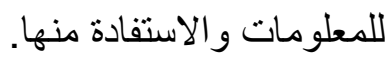
و يقسم الاعلام الذي تلتزم الثركات التي تكون أسهما محل قيد و تداول في التي البورصة إلى إعلام دوري و آخر ظرفي لألتركات

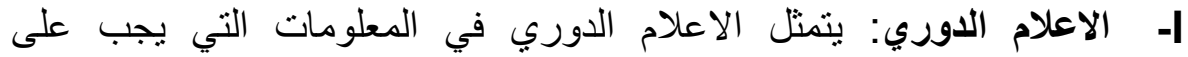

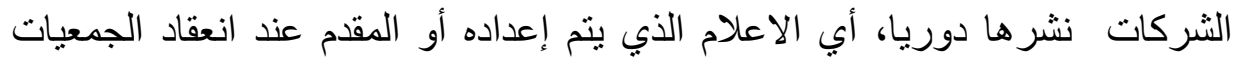
العامة العادية ، لا سيما المعلومات الحسابية و المالية.

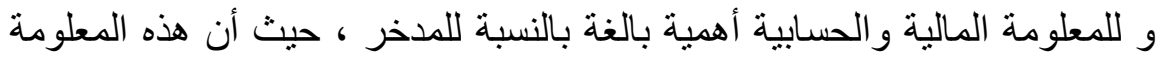

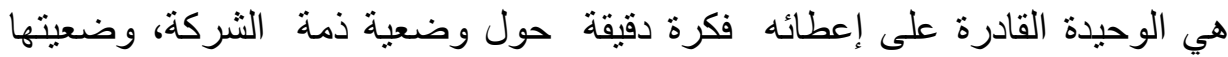
المالية، قدر اتها ، إمكاناتها ويسر ها الماليه المالي.

وحسب أحكام القانون التجاري فإن المعلومة المالية تكون محتواة في الوثائق التالية

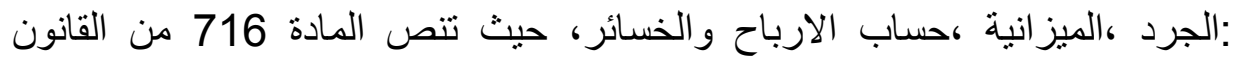

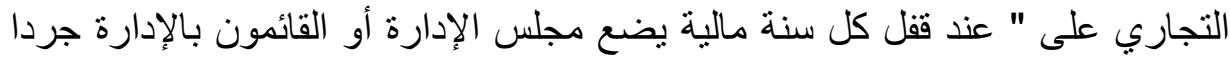

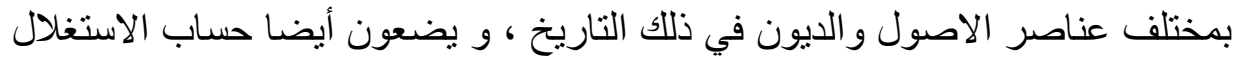

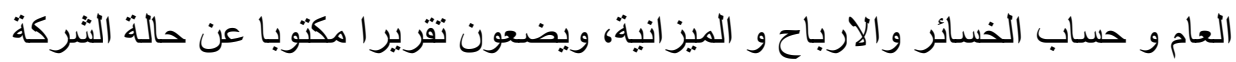
ونشاطها أثناء السنه المالية المنصرمة ".

إن الوثائق السابق ذكرها لا تحيط بالوضعية الكاملة والحقيقية للشركة ، فهي لا

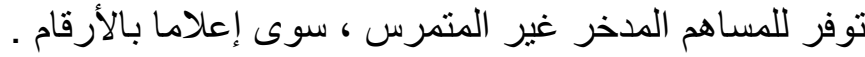


على ضوء ما سبق تدخلت لجنة تنظيم عمليات البورصة ومر اقبتها بإصدارها للنظام 2000-02 (35)، والذي فرض على تلى الشركات تقديم المعلومات المالية في شكل

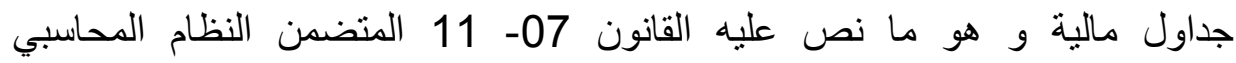
المالي. (36)

* الاعلام الواجب نشره بمناسبة انعقاد الجمعية العامة العادية: حسب نص المادة

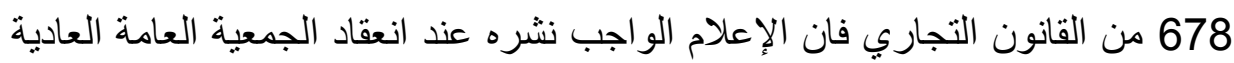

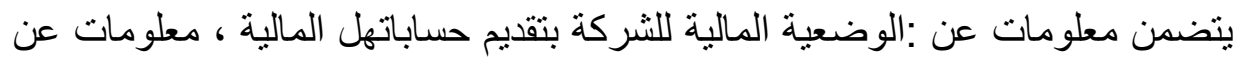

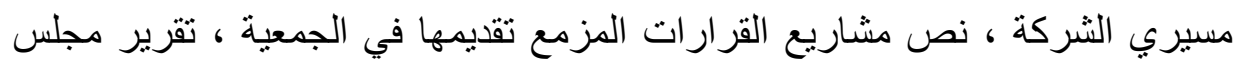
الادارة أو مجلس المديرين.

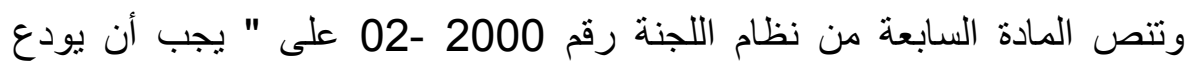
المصدر لدى اللجنة وشركة إدارة بورصة القيم تقريرا سنويا يحتوي على الجدائ الجداول

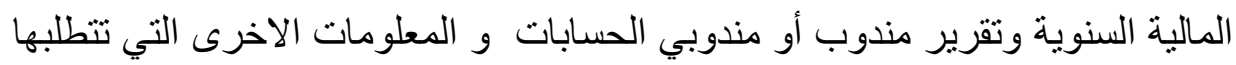
تعليمة الجنة وذلك ثنلاثين 30 يوما على الأكثر قبل اجتماع الجمعية الجية العامة العادية

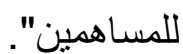

إضافة للتقرير السنوي الذي تلتزم الجهات المصدرة للقيم المنقولة بوضعه لدى

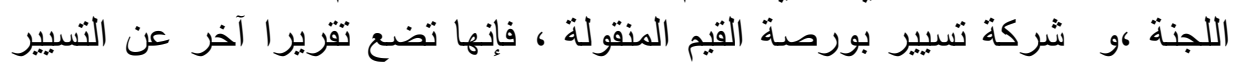
السداسي.

وبالرغم من أهمية المعلومات المدرجة سواء في التقرير السنوي أو التقرير

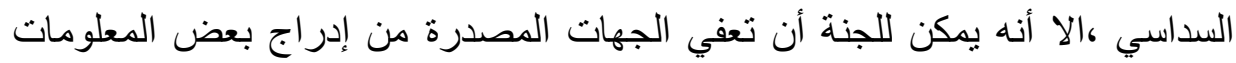

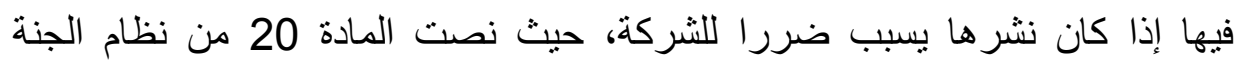

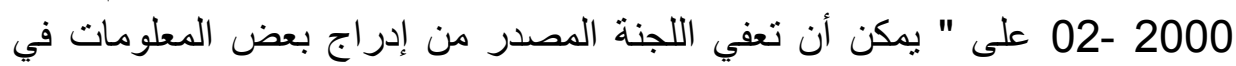

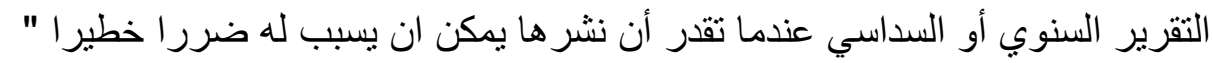
و حسب نص المادة فإن تقدير خطورة الضرر تركت للسلطة التقديرية للجنة . و حسب نص المادة 35 من المرسوم التشريعي 93- 10 المعدل و المتمم فان لجنة

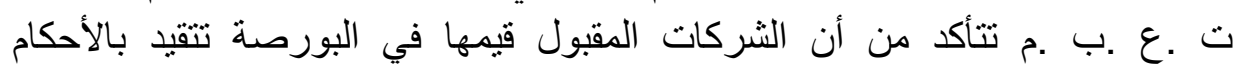

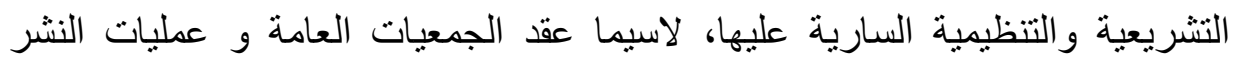


إن وظيفة المراقبة المنوطة بلجنة ت.ع.ب.م في هذا السياق، تتجسد في إلزام كل

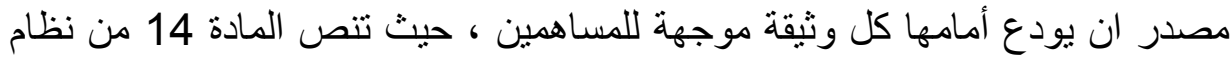

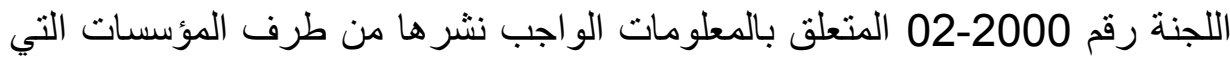

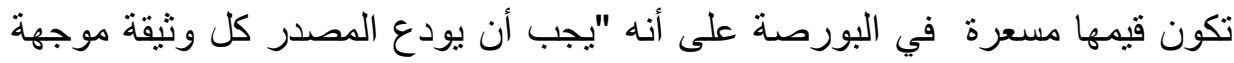

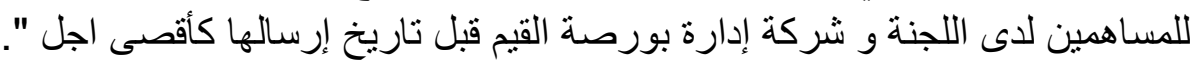

||-الإعلام الظرفي: على خلاف المعلومات الدورية فإن المعلومات الظرفية أو

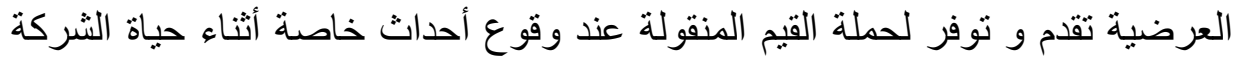
،أحداث يمكن أن تهم المساهمين ولها تأثثر على على حقوقهم ومصالحهم في الثركة ،ويمكن تقسيم الإعلام الظرفي إلى تهم:

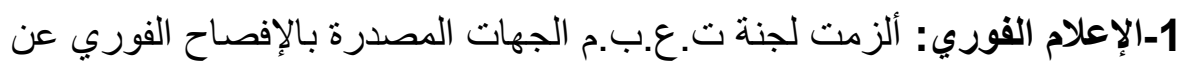

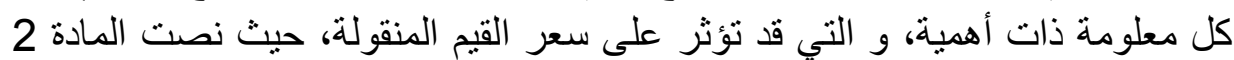
من نظام ل.ت.ع.ب.م رقم 2000- 02 على " يجب على على الهئ المصدر إعلام الجمهور

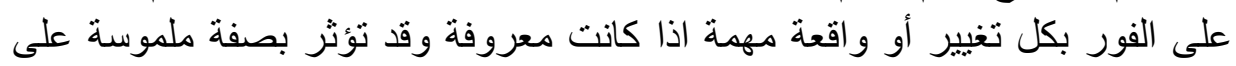
سعر القيم المنقولة".

إن هذه التغيرات و الأحداث الخاصة يمكن أن تهم وتمس بحقوق المساهم و

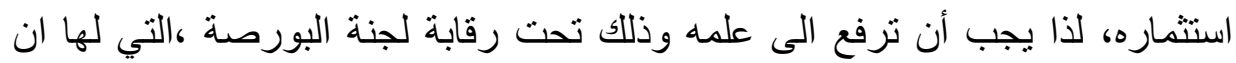
تطالب المصدر بنشر بعض المعلومات إذا اقتضت حماية المستثمرين أو حسن سير السوق ذلك(37).

وقد تقوم الثركات المصدرة بنشر المعلومات الهامة عن طريق البيانات الصحفية

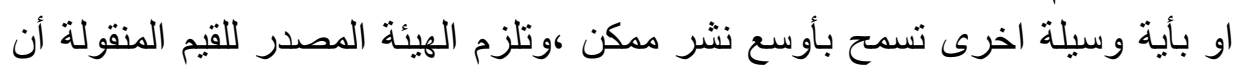
يرسل جميع البيانات الصحفية إلى لجنة البوريلة تبرة ورهذا في أجل لا يتجاوز تاريخ نشر ها(38).

و قد خولت اللجنة لمصدر القيم المنقولة إذا كان قادرا على ضمان السرية الازمة

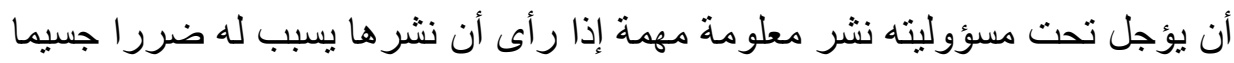

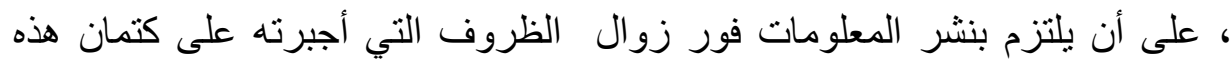
المعلومة(39).

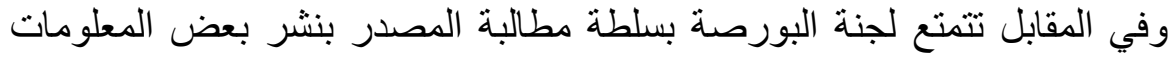

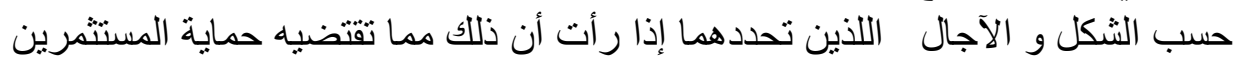


أو حسن سير بورصة القيم المنقولة، و في حالة عدم التزام المصدر بو اجباته فإنه يمكن لها نشر هذه المعلومات ويتحمل المصدر تكاليف هذا النشر (40.)

2- الاعلام المناسباتي: لم تحدد لجنة البورصة في نظامها رقم 2000 -02 الجة

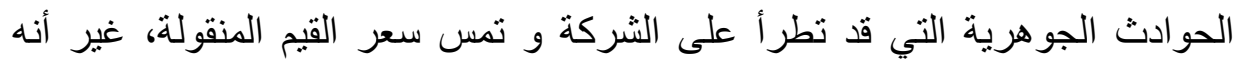

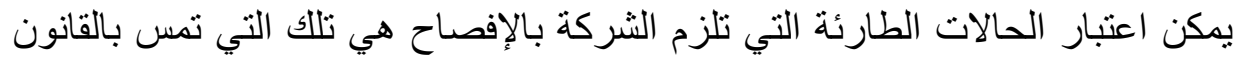

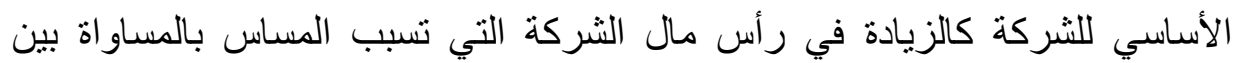

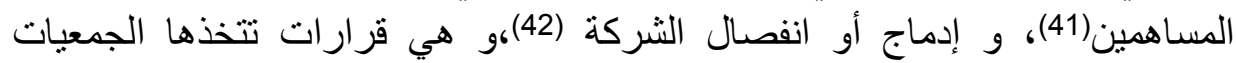

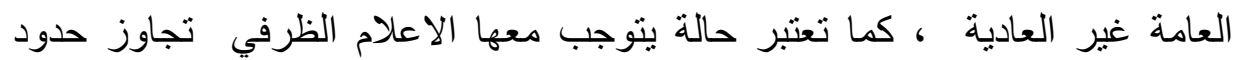
المساهمة(43).

الأ- نوعية الاعلام: إذا كان الحق في الإفصاح يتضمن الحق في الحصول على

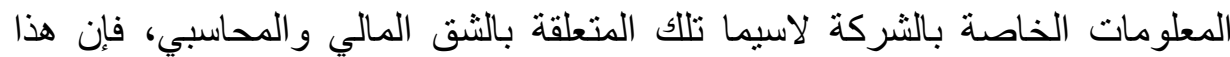

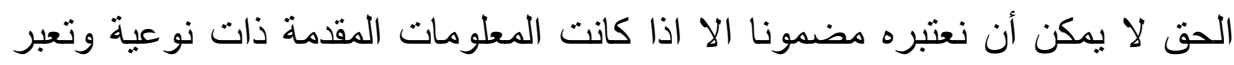
فعلا عن الحقيقة ، لاسيما ما تعلق بالمعلومات العات المالية.

إن المادة 4 من نظام لجنة ت.ع.ب.م رقم 2000-02 الذي يتعلق بالمعلومات

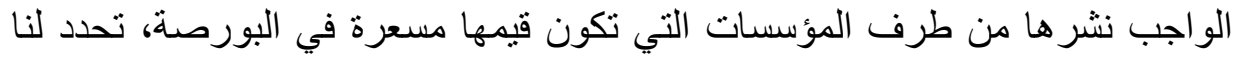

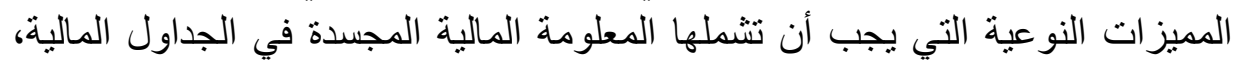

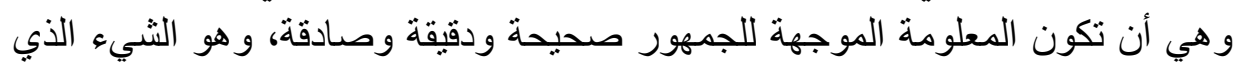
يضمن إدلاء و إعطاء معلومات مالية نافعة لاتخاذ القرار الذي يقبل المدخر وهر على وهلى

ونصت المادة 8 من المرسوم التنفيذي رقم 08-156(44) الذي يتضمن تطبيق أحكام

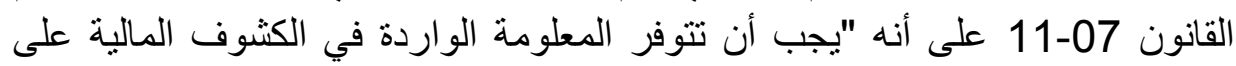

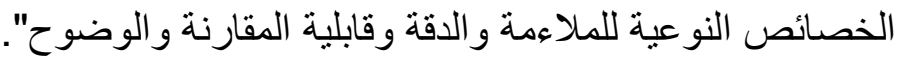

من خلال هذه النصوص يلاحظ أن المشرع يسعى لتوفير إعلام كمي و نوعي ملائم

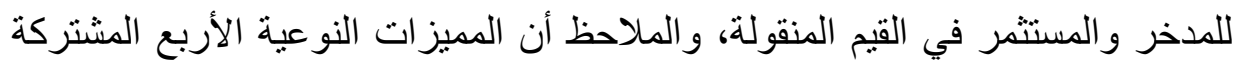

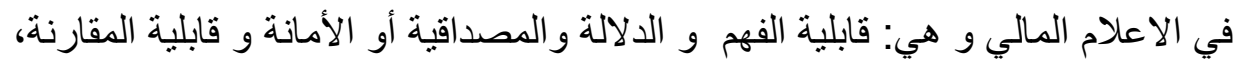

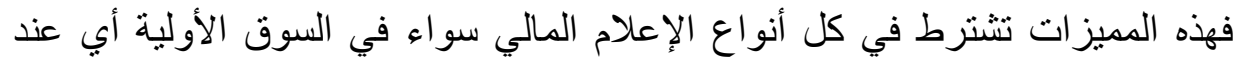

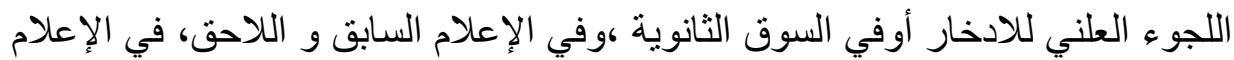


الدوري الإعلام الظرفي بل ويجب أن تتوفر هذه المميزات في كل المعلومات المقدمة

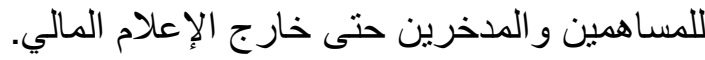

Iألاوات الرقابة على واجب الإفصاح وحمايته القانونية : إن وظيفة الرقابة التي

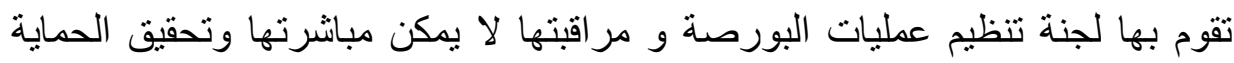
المرغوب فيها دون عدد من الوسائل أو الصلاحيات ،و أول وسيلة تمارس بها اللجنة

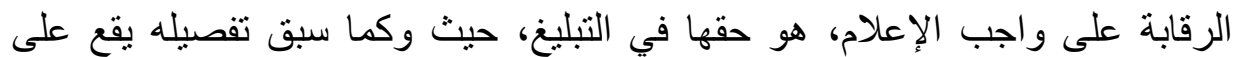

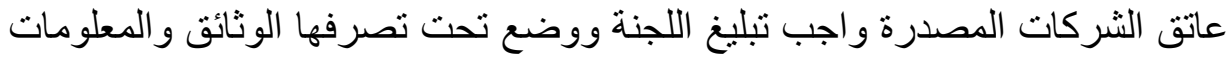
التي أثنارت اليها النصوص التشريعية والتنظيمية لاسيما أنظمة اللجنة، سواء المذاء التهرة

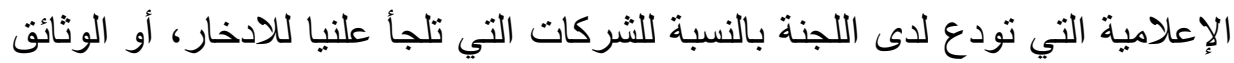
التي تودع لدى اللجنة بمناسبة الإعلام الدوري او الإعلام الظرفي السابق التفصيل

من جهة أخرى فإنه ومن أجل تحقيق سوق عادل و شفاف، تلتزم الجهات الرقابية

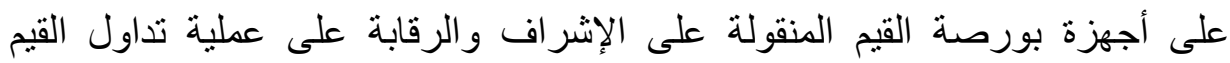
المنقولة المدرجة، وذلك بتلقي المعلومات والبيانات من الجهات المصدرة ،ولهذا تحرص الجهات الضابطة لسوق القيم على إلزام الجهات المعنية بتنفيذ واجبها

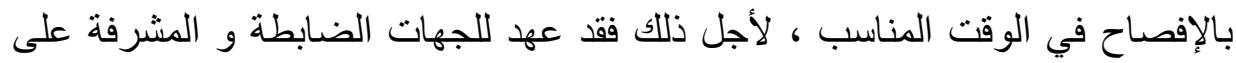
الأسواق المالية سلطة إتخاذ تدابير وقائية وأخرى علاجية.

1- التدابير الوقائية: إذا وققت لجنة البورصة على مخالفة للأحكام التشريعية

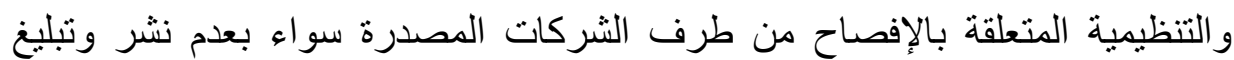

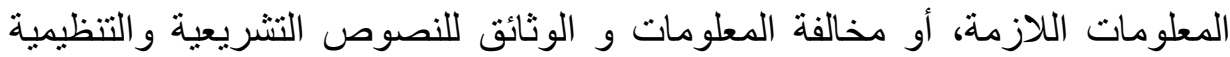
فإن للجنة أن تتدخل بمعالجة هذه التجاوزات، لكن قبل الوصول للحل العلاجي فإن الت التهات

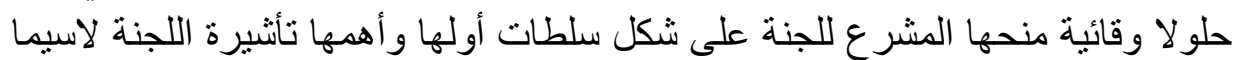

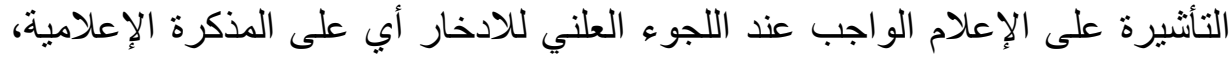

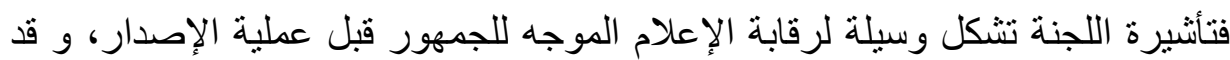

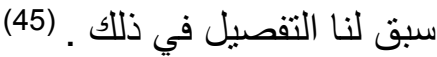
أما بالنسبة للإعلام الذي لا يخضع لتأثيرة اللجنة وتحديدا الإعلام قبل انعقاد الجمعيات العامة للمساهمين العادية والغير العادية، حيث تمارس عليه اللجنة رقابه

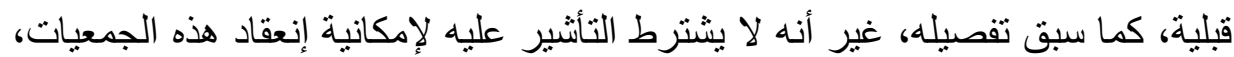

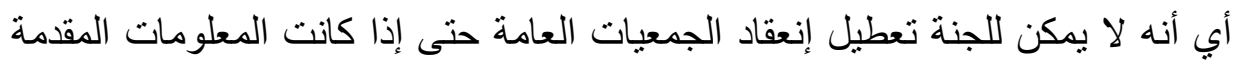


غير مطابقة للمتطلبات التشريعية و التنظيمية، و قد يعود السبب لصعوبة ذلك عمليا،

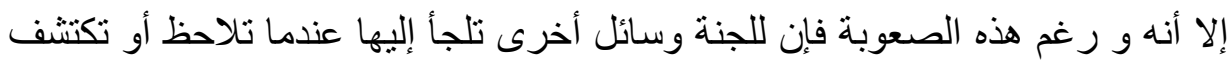

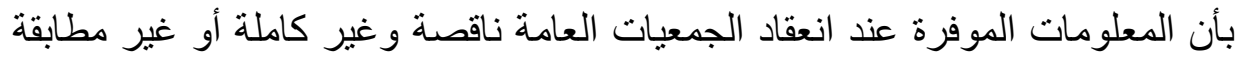

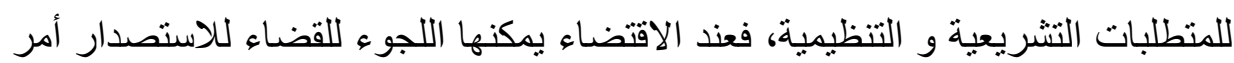

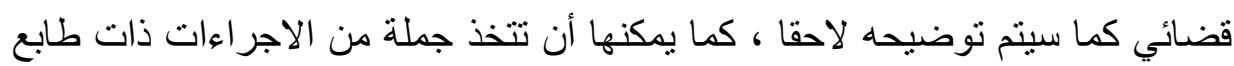

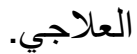

2- التدابير ذات الطابع العلاجي : قد لا تلتزم الثركات المصدرة للقيم المنقولة و

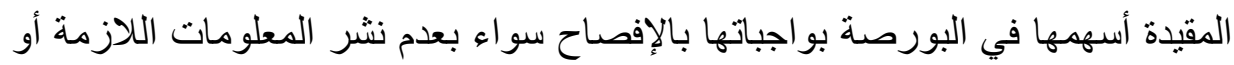

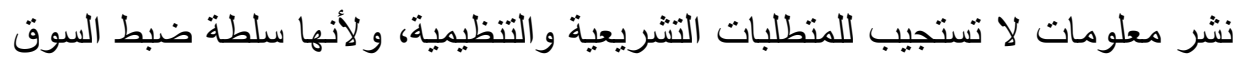

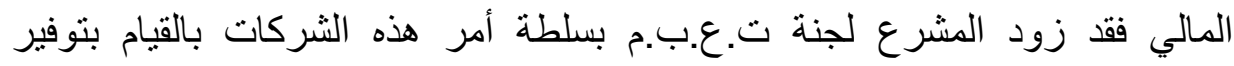

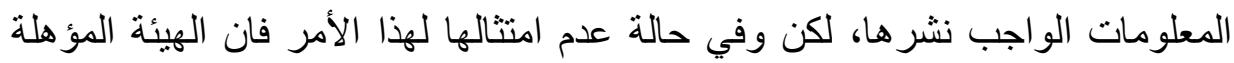
لأن تحل محل الهيئات المصدرة للقيم المنقولة في نشر هذا، هذه عام المعلومات.

أ- سلطة الأمر (l'injonction) : حسب نص المادة 35 من المرسوم التشريعي

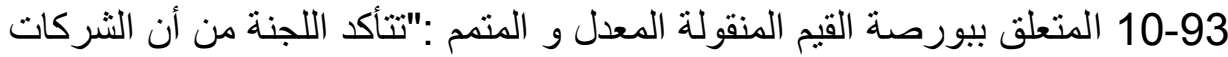

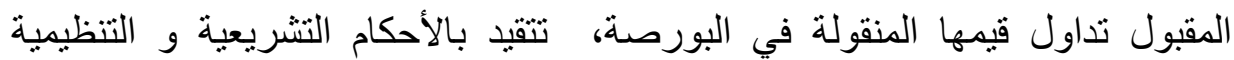

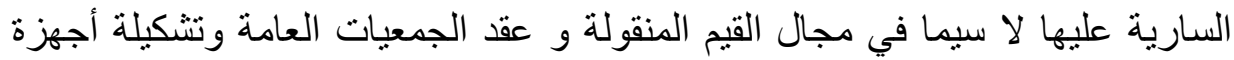
الإدارة والرقابة و عمليات النشر القانونية.

و تأمر هذه الثركات، عند الاقتضاء بنشر استدر اكات فيها اذا لوحظت حالات سهو في الوثائق المنشورة أو المقدمة ". و وعليه فإن من مظاهر الرقابة الممنوحة للجنة باعتبار ها سلطة ضبط سلطة إصدار

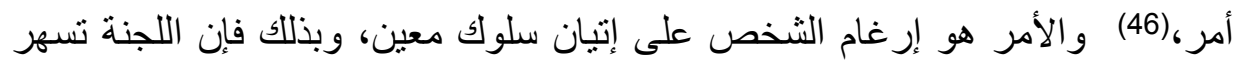

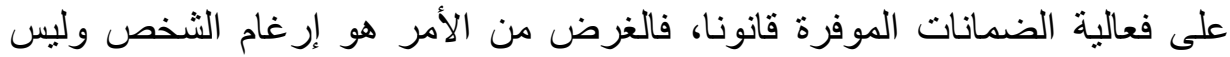

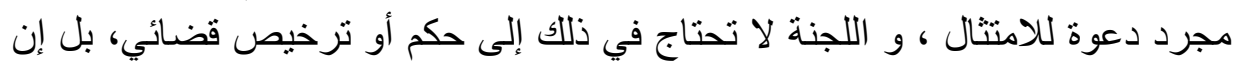

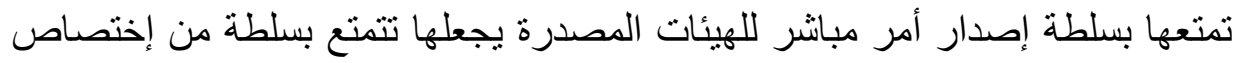
الجهات القضائية، فهذه السلطة تعود لرئيس المحكمة، بالرغم من كون اللجنة هيئة

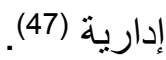




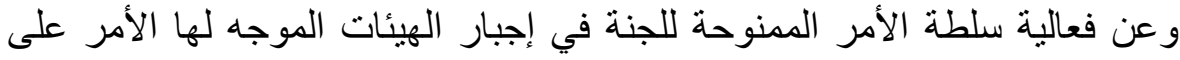

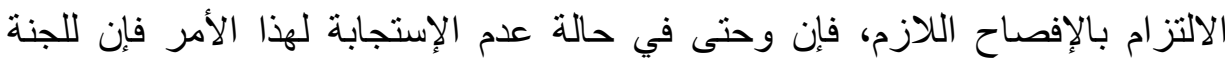

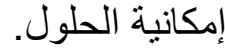

ب- الحلول(la substitution): يشكل هذا الإجراء أنسب الأدوات و الوسائل المقررة قانونا التي تتمتع بها هيئة السوق لضمان إعلام ملائم للمدخرين، وبالتالي الحفاظو صون حقوقهم المشروعة.

تتص المادة 6 من نظام لجنة ت.ع ب.م رقم 2000-02 على "يمكن اللجنة، إذا

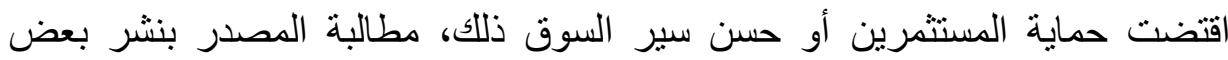
المعلومات حسب الأشكال والآجل اللذين تحددهما. وفي حالة عدم إلتزام المصدر بواجباته، يمكن اللجنة القيام بنشر بهذه المعلومات، و على المصدر أن يتحمل تكاليف نشر ها " وبذلك تحل اللجنة محل مصدر القيم المنقولة في نشر المعلومات.

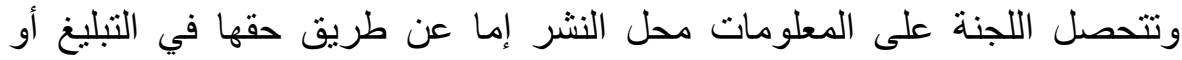
بمناسبة مباشرتها لوظيفة التحقيق التي تجريها لدى الثركات و الهيئات المصدرة، كما

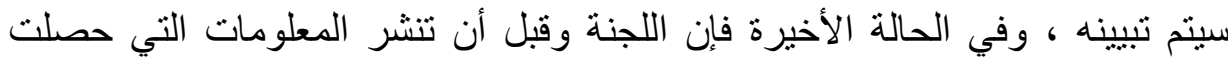
عليها، فإنها تطلب ذللك أو لا من الثركات المعنية.

وتأتي سلطة الأمر والحلول الممنوحة في إطار الأدوات والآليات القانونية التي رصدها المشروع لحماية مبدأ الافصاح في السوق المالية، لكن هذه الأدوات وحدها لن الن النات تكون كافية بدون حماية قانونية لهذا المبدأ. 3- حماية مبدأ الإفصاح: إن للجزاء أثر هام في الإحجام عن ارتكاب المخالفات،

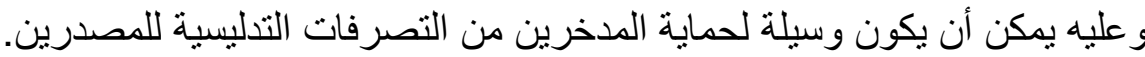

و في مجال الإعلام فقد نصت المادة 20 من المرسوم التشريعي 93- 10 على إلى

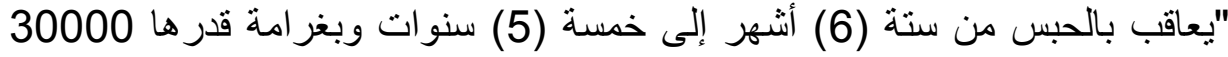

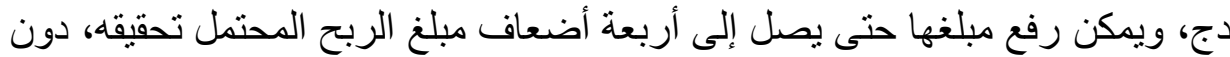

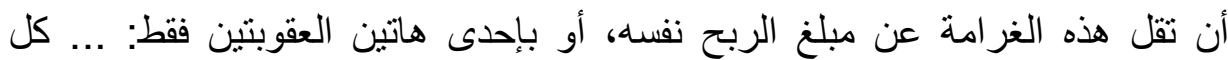
شخص يكون قد تعد نشر معلومات خاطئة أو مغالطة وسط الجمهور بطرق و وسائل فرئل 


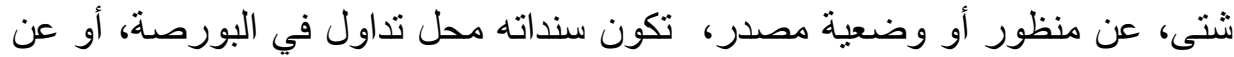
منظور تظور سند مقبول للتداول في البورصة، من شأنه التأثثر على الأسعار ..." . وبذلك فان المشرع الجز ائري لم ينص على جز اء الأشخاص الذين يقومون بإصدار

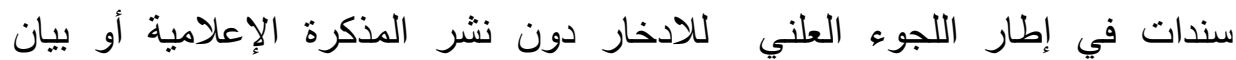
الإعلامي، أبي الإعلام في سوق الإصدار، وذللك عكس ما فعلته تشريعات أخرى(48)،

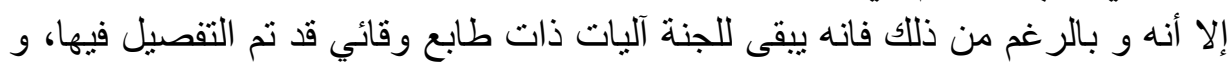

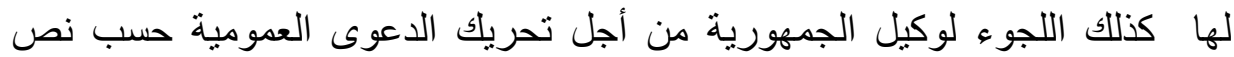
المادة 40 من المرسوم التشريعي 93 -10.

ونقول أخير ا أن المشرع قد حرص على الزام الثركات المصدرة للأوراق المالية

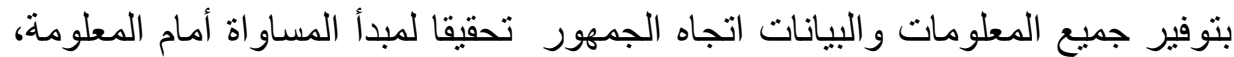

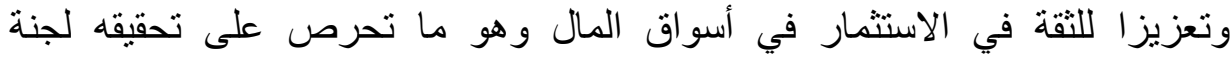

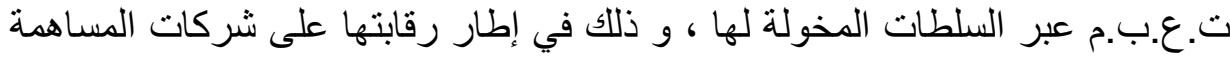

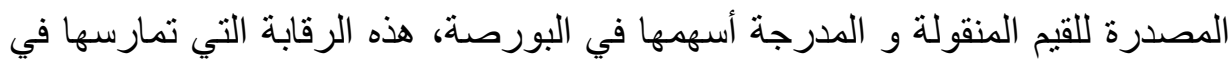
السوق الثانوية كما في السوق الأولية.

المطلب الثاني: آليات الرقابة على شركات المساهمة في سوق التداول (السوق : الثانوية)

سميت هذه السوق بالسوق الثانوية لأنها السوق التي تتداول فيها المنتوجات المالية

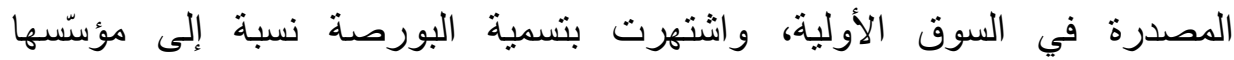
الأول VANDER BOURS، ظظهرت أول بورصة في بلجيكا عام 1531 ، لتليها بورصة ليون بفرنسا، ثم بورصة باريس التي أنشئت بموجب قروفة فرار من البلاط الملكي

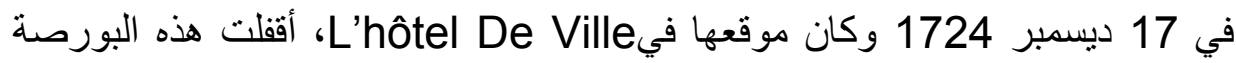
Le عند بداية الثورة الفرنسية لكنها الستأنفت نشاطها في 1808 داخل القصر الملكية

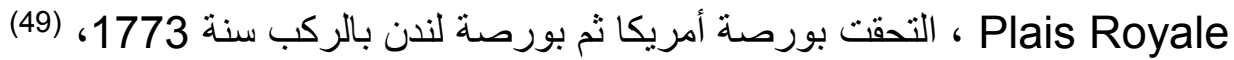
لتنتشر هذه التقنية الاقتصادية في كافة أنحاء العالم.

و عرفت بورصة القيم المنقولة بعدة تعاريف يذكر منها " هي السوق المنظمة التي تعقد فيها عمليات يكون موضو عها تداول الأوراق المالية في حصص يودية أو دورية دورية،

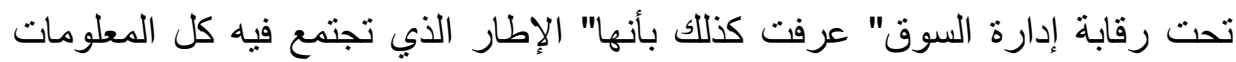

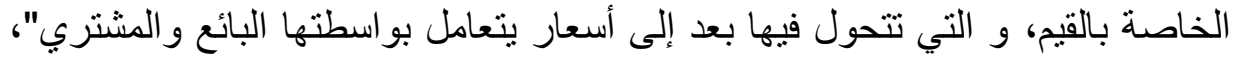


و يدل مصطلح البورصة على معان مختلفة فهو يدل على المكان الذي تتعقد فيه

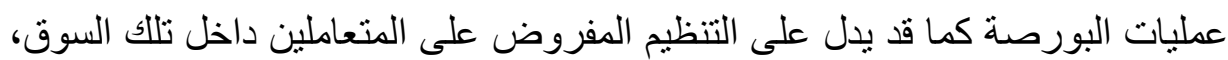
و أخير ا قد يدل على الحصص اليومية أو الدورية التي تعقد فيها تلك العمليات.

وتمتاز السوق الثانوية بدقة وتعقبد العمليات المنجزة فيها، لذى بجب أن برافقها تأطير قانوني محكم و رقابة هامة تضمن حماية السوق و المتعاملين فيها، وذللك بتحديد

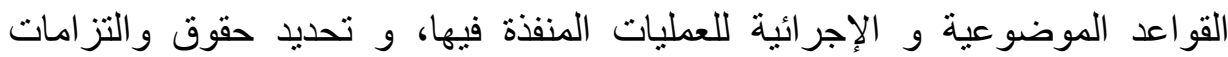

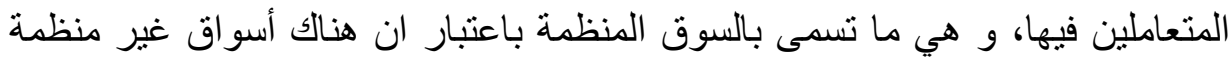

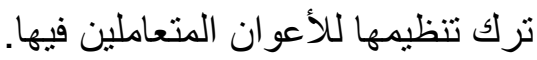

وتعتبر بورصة الجزائر سوق منظمة تخضع لإطار قانوني محكم، إذ أولاها

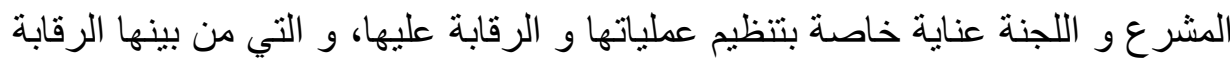

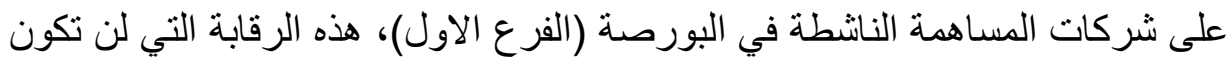

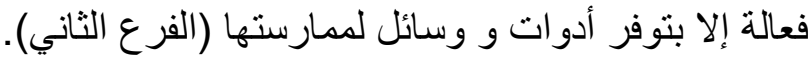

\section{الفرع الاول: الرقابة على القيد في البورصة :}

يقصد بقيد الأوراق المالية عملية إدراجها في جداول البورصة، ويعتبر القيد في

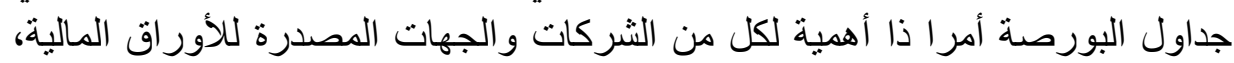

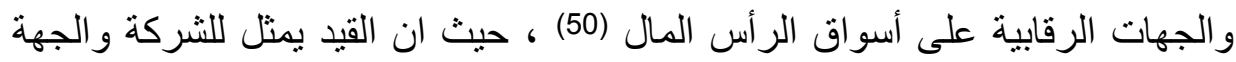

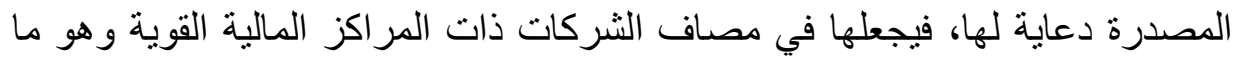

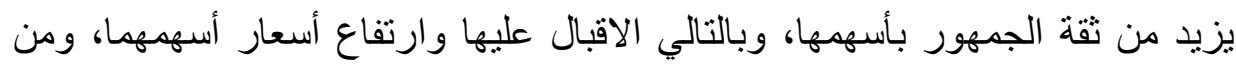

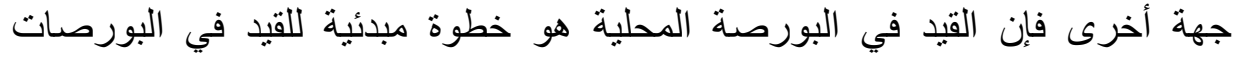
الخارجية وما يتبع ذلك من تعريف للثركة في الأسو اق الخارجية.

ويمثل القيد لجمهور المستثمرين، توافر المعلومات عن الثركة و بالتالي مراقبة

أسعار أور اقها المالية باستمرار و هو ما يزيد من ثقة الجمهور في أسهم الثركة (51). و كذلك هدف المشرع من اشتر اط قبد الوراق المالية بالبورصة، إلى تفعيل دور

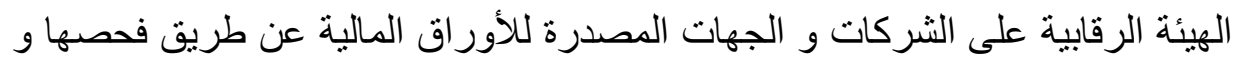

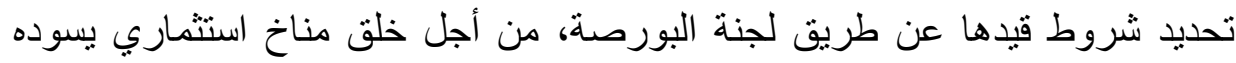

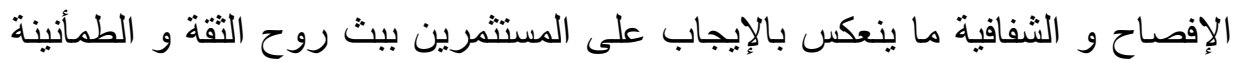
في نفوسهم، وللقيد شروط (أولا) و إجر اءات (ثانيا ). 


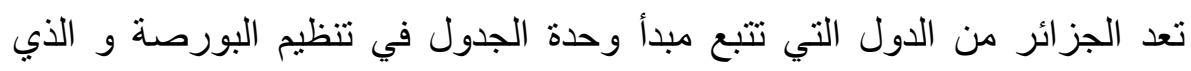

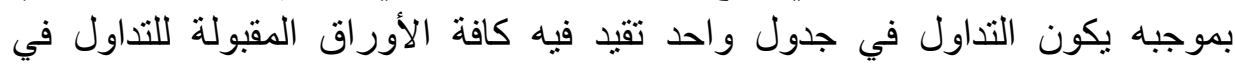
البورصة، فقد انطلقت الجزائر بسوق وحيدة هي السوق الرون وسمية لسندات رأس المال و

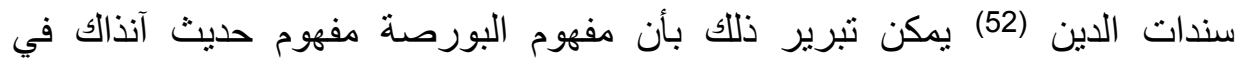

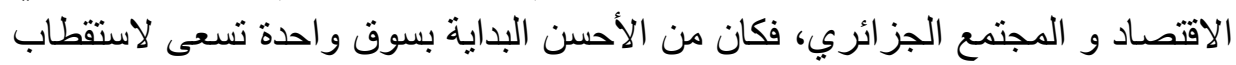

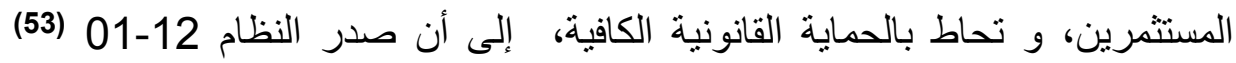

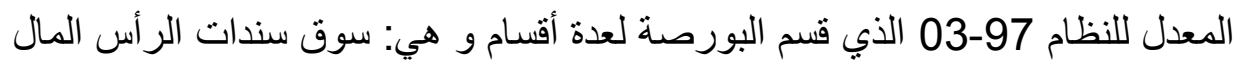

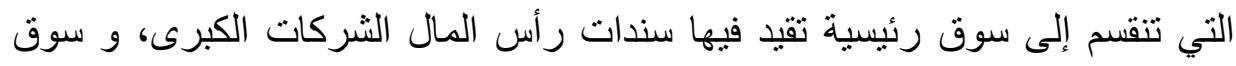

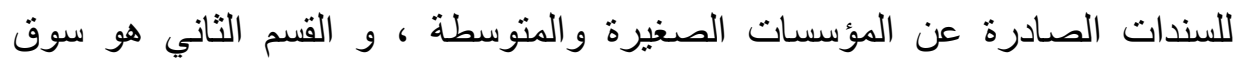

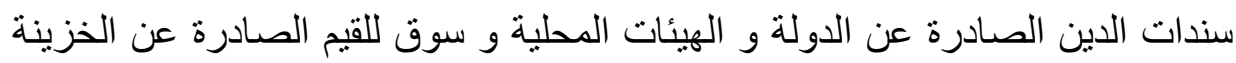
العمومية.

و لأن موضو عنا هو الرقابة على شركات المساهمة التي تكون أسههها محل تداول في البورصة فإننا سنتناول قيد سندات رأس المال بقسميها.

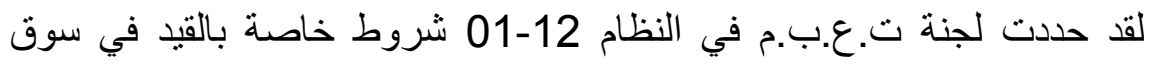

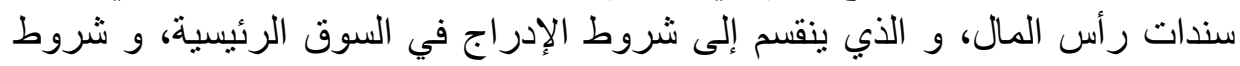
الإدر اج في سوق المؤسسات الصغيرة و المتو المتوسطة. ا- شروط القيد في السوق الرئيسة : تتعلق السوق الرئيسة بالثركات الكبرى و

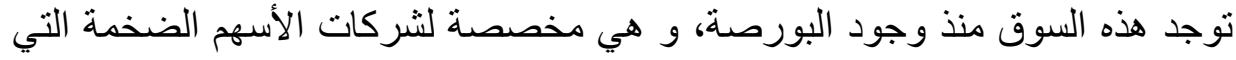

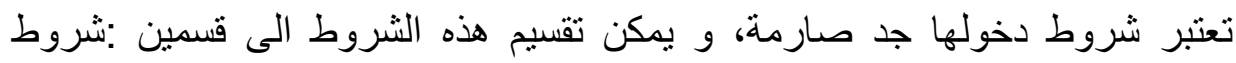
خاصة بالشركة المصدرة ، وشروط متعلقة بالقيم المنقولة المر غوب هون قيدها. 1- الثروط الخاصة بالثركة المصدرة: يجب على الثركة المصدرة التي تقدم طلب قيد قيمها المنقولة في البورصة أن تثبت تو افرها على الثروطي الثروط الاتية: - أن تكون الثركة شركة أسهم منشأة وفقا للقواعد والإجراءات المنصوص عليها في

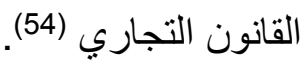

ـعلى الثركة أن تنشر الكثوف المالية المصادق عليها للسنتين الماليتين السابقتين للسنة التي تم خلالها تقديم طلب القبول ما لم تقرر اللجنة خلاف ذلك (55). 
- يجب على الثركة أن تثبت بأنها حققت أرباحا مالية خلال السنة المالية السابقة لطلب القبول (56).

- يجب على الثركة تقديم تقرير تقييمي لأصولها، ينجزه عضو من المنظمة الوطنية

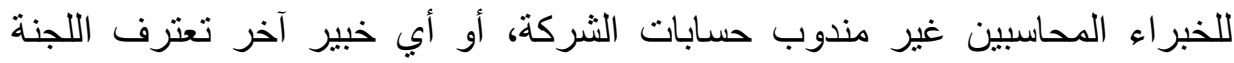
بتقبيمه.

- يجب أن يبرر وجود هيئة الرقابة الداخلية، تكون محل تقييم من طرف مندوب

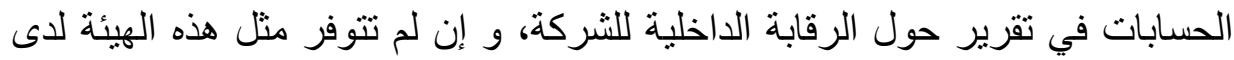

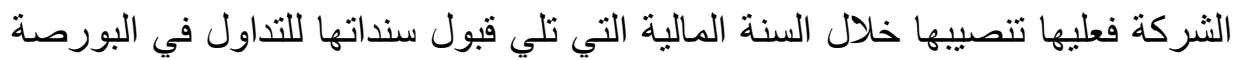

- أن تتكفل الثركة بعملية تحويل السندات، و إذا بقي مساهم غير الدولة أو شركة

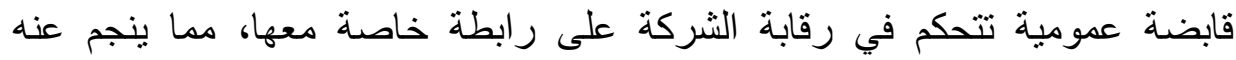

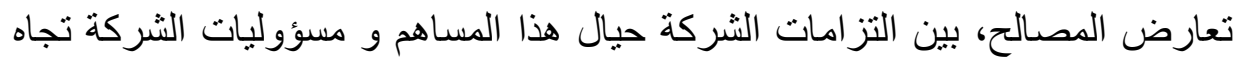
كل المساهمين فها، لا يقبل قيد هذه الثركة في البورصة (58).

- يجب على الثركة التي تطلب قبول سندات رأسمالها للتداول في السوق الرئيسية، أن لا تقل قيمة رأسمالها الذي تم وفاؤه عن خمسمائة مليون دينار (500.000.000 دج )

ـ أن توزع على الجمهور سندات تمثل نسبة 20\% من رأس المال الاجتماعي للشركة وذلك يوم الإدر اج على أبعد تقدير (60).

- و اشترطت المادة 17 من النظام رقم 03-97 على الثركة(61)، تعيين وسيط لمساعدة المصدر في إجراءات القبول و الإدخال، و عليه التأكد من توافر الثروط المذكورة.

و الملاحظ على هذه الثروط الموضوعة من قبل لجنة البورصة ، أنها تهدف في

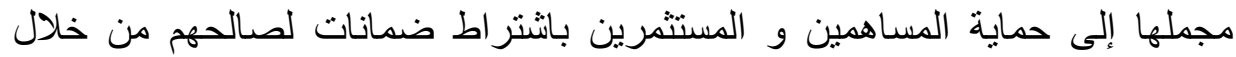

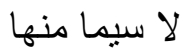

التأكد من وضعية الشركة المالية، كل ذلك تحت رقابة اللجنة التي سعت إلى دعم حماية المستثمرين في القيم المنقولة 


\section{2- الشروط الخاصة بالأوراق المالية و هي :}

- - يجب أن تكون الأسهم محل طلب القبول مدفوعة بكاملها ـ (62)

- يجب توزيع سندات رأس المال على جمهور يقدر ب 150 مساهم على الأقل،

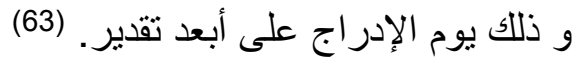

\section{Iا- شروط القيد في سوق المؤسسات الصغيرة و المتوسطة :}

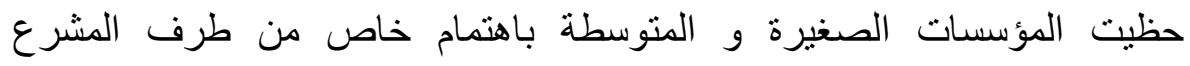

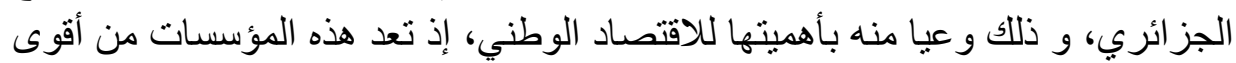

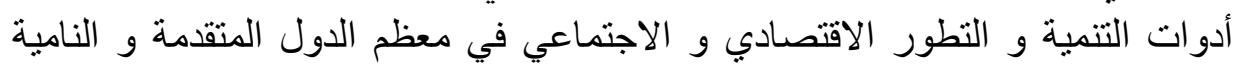

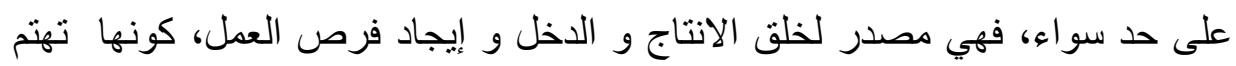
بالأنشطة الانتاجية الخدماتية و الفكرية.

و بدأ مشوار المشرع الجزائري مع المؤسسات الصغيرة و المتوسطة بإصداره

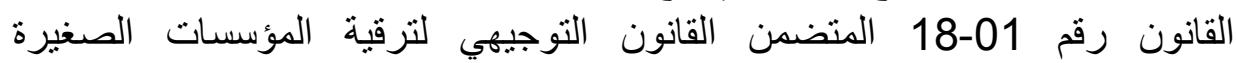

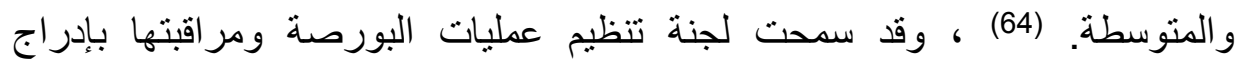

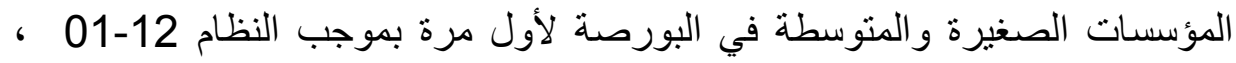
بسندات رأس المال دون سندات الدين.

وضع النظام رقم 12-12 شروط خاصة لإدخال سندات رأسمال المؤسسات

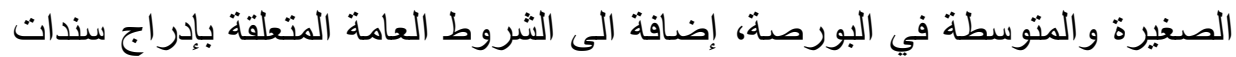

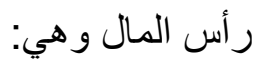

- يجب أن تكون المؤسسة الصغيرة أو المتوسطة ذات نظام شركة أسهم، كما يجب

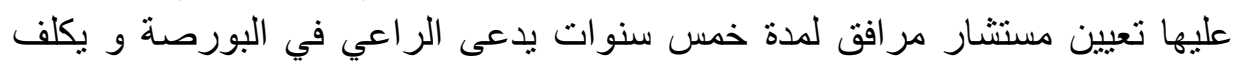

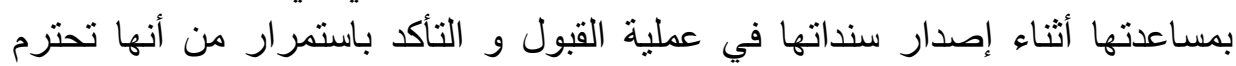
التزاماتها القانونية و التنظيمية في مجال الاعلام. (65)

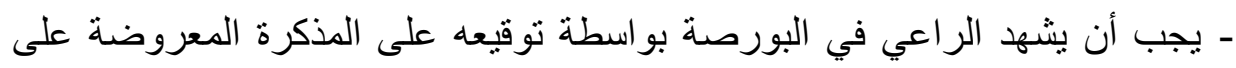

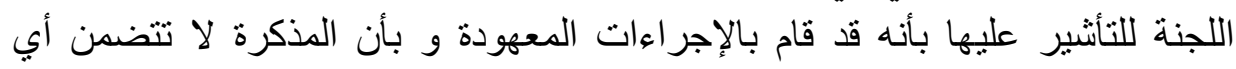

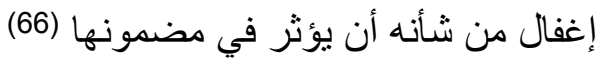


- يجب أن يكون الراعي في البورصة وسيطا معتمدا في عمليات البورصة، أو بنكا ،

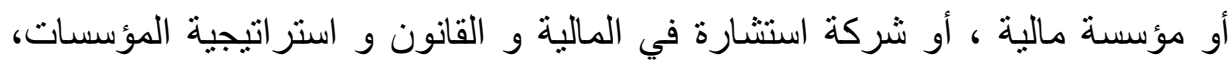

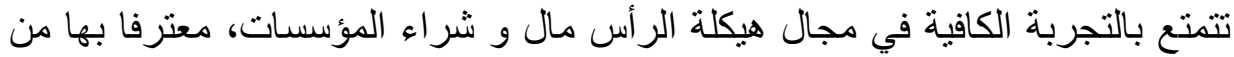
اللجنة و مسجلة لديها، حدت شروط و اجراءات تسجيل الشركة المرشحة لممارسة وظيفة الر اعي في البورصة بموجب تعليمة من البورصة (67)

- يجب ان تكون الشركة قد أبرمت مع الراعي في البورصة اتفاقية يتم إعدادها

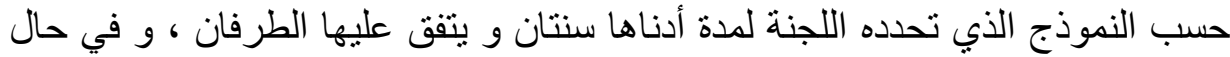
فسخ الاتفاقية يجب على الثركة ان تعين على الفور راعيا آخر و تبلغ اللجنة بذلك. (68) - يجب أن تكون الثركة قد نشرت كثوفها المالية المصادق عليها عن السنتين

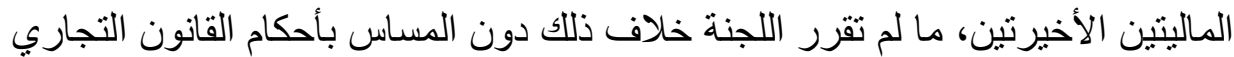

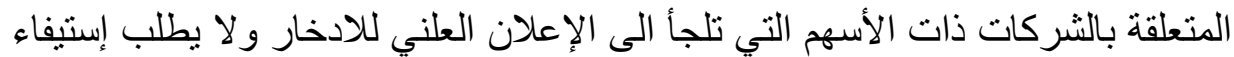
شروط الربحية و الر أسمال الأدنى من الثركات التي تطلب قبولهات لها في سوق المؤسسات

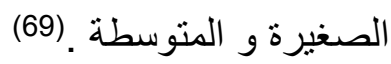

- يجب أن تفتح الثركة رأسمالها الاجتماعي على مستوى أدناه 10\% وذلك يوم الإدر اج على أبعد تقدير.

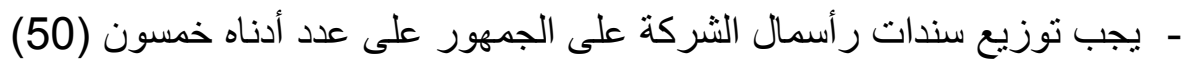
مساهما ، أو ثلاثة مستثمرين مؤسساتيين من بنوك و مؤسسات مالية، شركات تأمين،

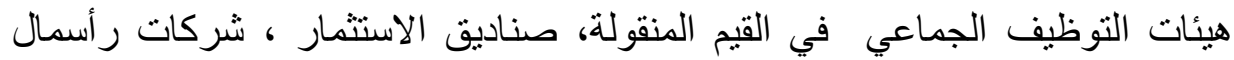
الاستثمار والشركات المسيرة للأصول، وذلك يوم الادر اج على أبعد تقدير (70)

وسمحت اللجنة للشركة المقيدة في سوق المؤسسات الصغيرة و المتوسطة، بنقل

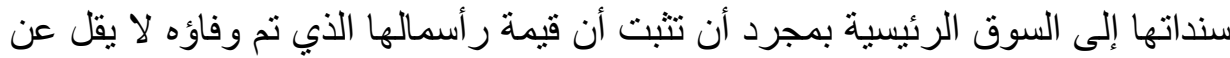
خمسمائة مليون دينار جز ائري (500.000.000 دج ) (71) و عليه بمكن اعتبار سوق المؤسسات الصغيرة و المتوسطة بمثابة سوق انتظار أي مرحلة أولية تمر بها الثركة في انتظار توفر ها على شروط الثوات القيد القيد في السوق الرئيسية، حينها تكون قد تموقعت في السوق و اكتسبت الخبرة الكافية (72)، هذا عن شروط القيد. ثانيا : إجراعات القيد تعتبر القو اعد الإجرائية للقيد في البورصة قو اعد مهنية بحتة صادرة عن كل من لجنة تنظيم عمليات البورصة و مرافير الفتها في شكل أنظمة و و 
تعليمات، و أخرى صادرة عن شركة تسيير بورصة القيم في شكل مقررات، وتشكل

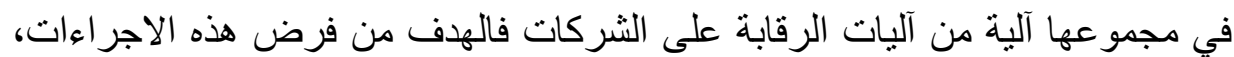

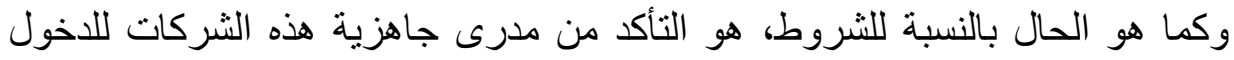

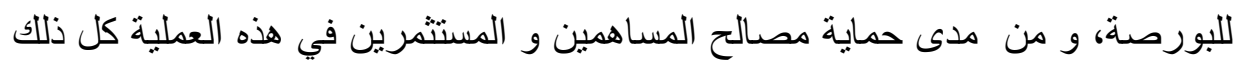
تحت رقابة اللجنة.

بتوفر ها على شروط القيد المذكورة آنفا تسعى الثركة للحصول على قبول اللجنة

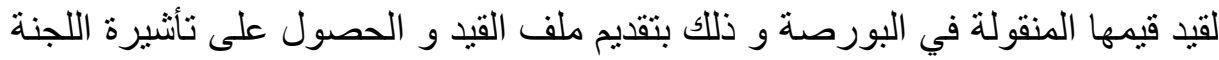

ا- ملف القيا : نودع الثركة الراغبة في قيد قيمها المنقولة في البورصة طلبا لدى الدى

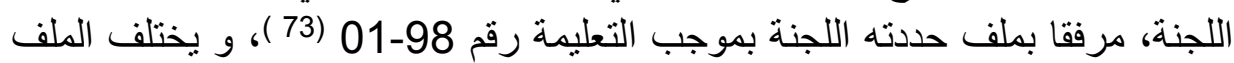
باختلاف القيم المرغوب قيدها إذا كانت سندات ر أس مال أو سندات دين.

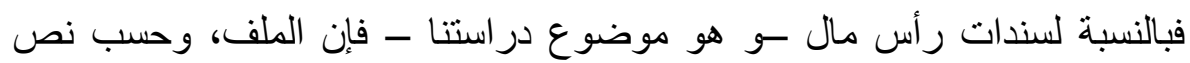

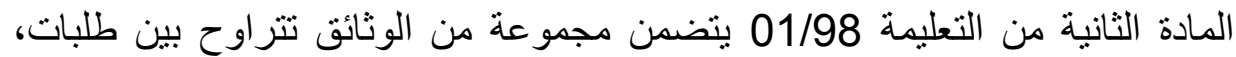

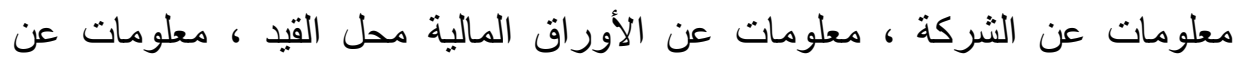

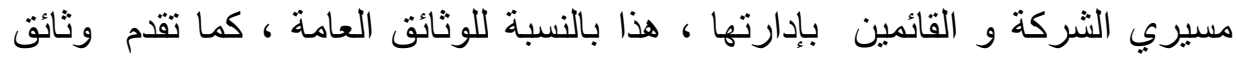

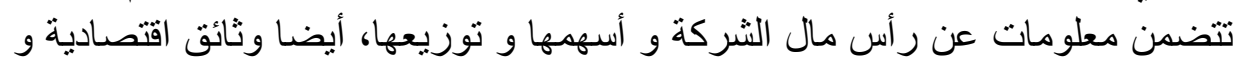

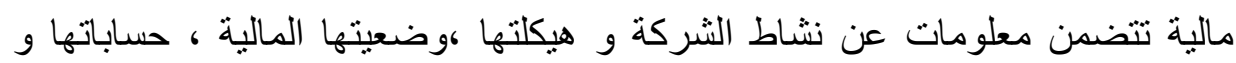

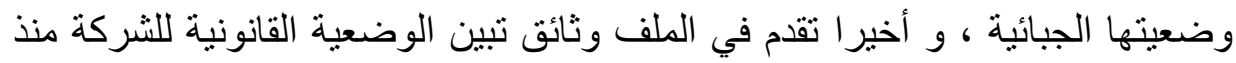

إن الاجراءات المتبعة للقبد في البورصة لا يمكن إلا أن تكون آلية ووسيلة رقابة

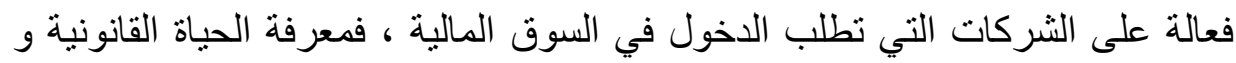

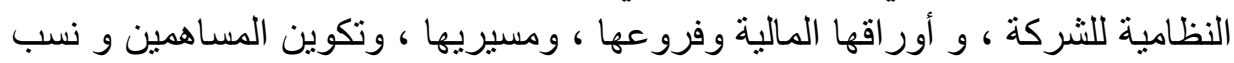

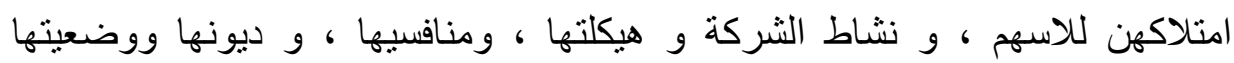

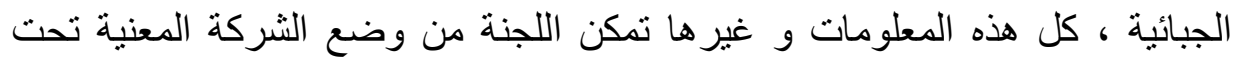

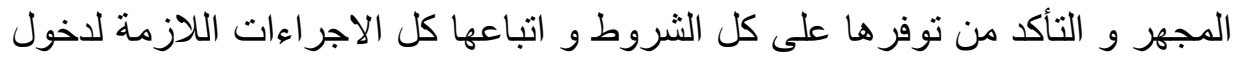
البورصة.

ال- التأشير على المذكرة الاعلامية : تلزم الثركة التي ترغب في قيد قيمها المنقولة

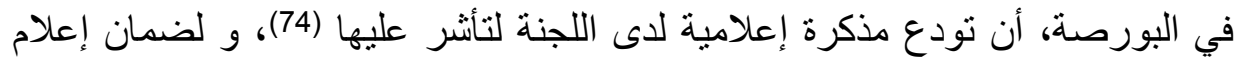


نوعي و حماية لمصالح المستثرين ، للجنة أن تطلب كل المعلومات و الوثائق المكملة، كلما تبين لها غموض أو نقص فيما قدم لها (75) ، وذلك في أجل أقصاه شهر ألهر من تاريخ استلام ملف طلب القبول .

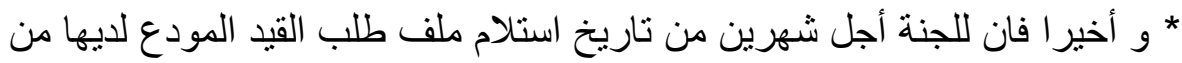

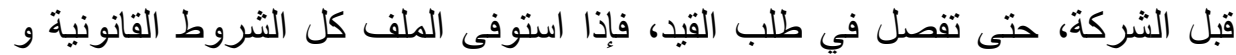

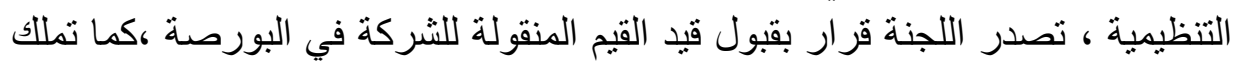

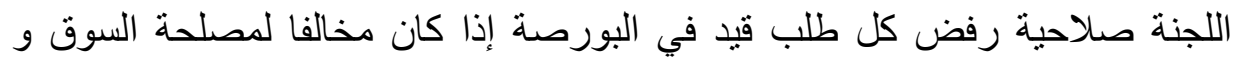

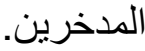

الفرع الثاني : آليات رقابة لجنة تنظيم عمليات البورصة ومراقبتها على سوق

لتحقيق سوق عادل و شفاف ثلتزم الجهات الرقابية على أجهزة البورصة على البى

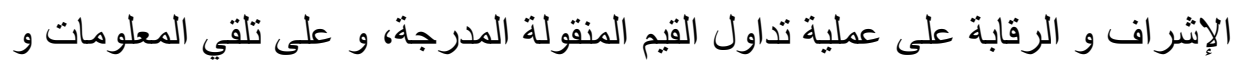

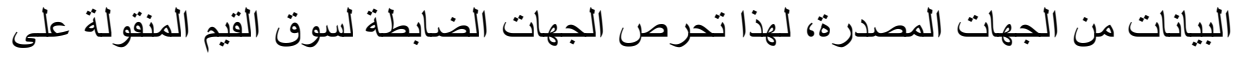

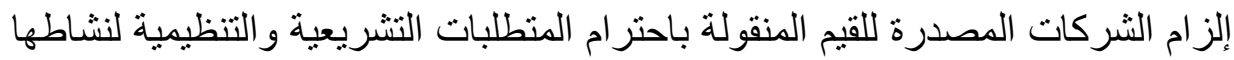

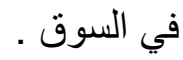

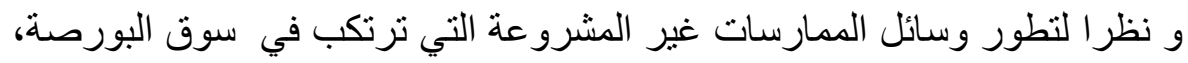

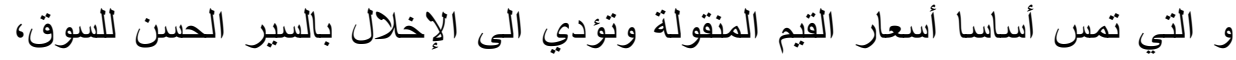

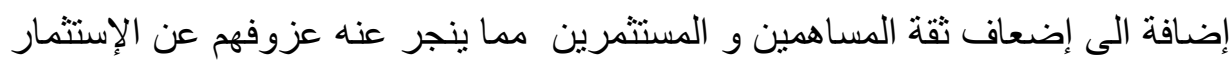

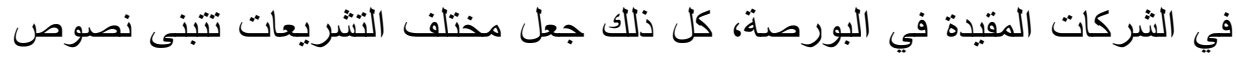

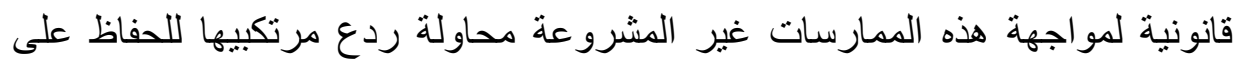
أمن و سلامة التداول في البورصة لمده المارسات (76 ).

و لا يمكن مواجهة هذه الممارسات بدون أن تتمتع هيئات مر اقبة السوق بوسائل و آليات و سلطات تمكنها من ممارسة رقابة قوية على السوق، و من بين هذه الآليات و

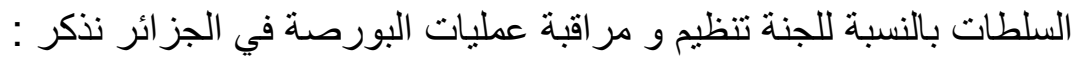

اولا : سلطة التحقيق : قد تلجأ الأطراف الفاعلة في بورصة القيم المنقولة و

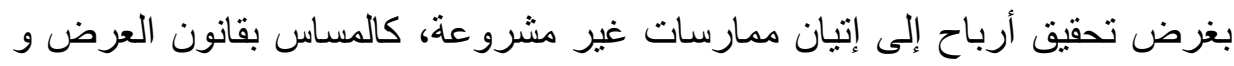

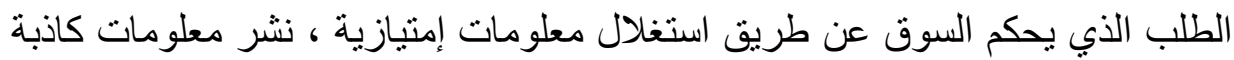
أو مضللة، التلاعب بالأسعار ، و غير ها من الممارسات. 
لقد خول المشرع للجنة البورصة سلطة إجرا ء تحقيقات، وذللك بموجب المادة 37 من المرسوم التشريعي 10-93 التي تتص على "تجري التهنة اللجنة عن طريق مداولة

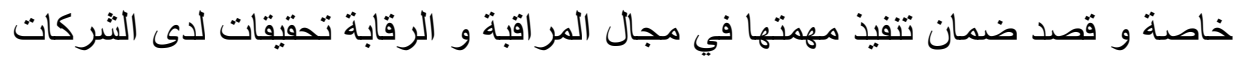

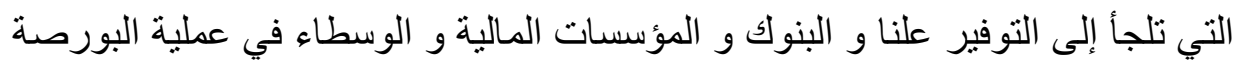

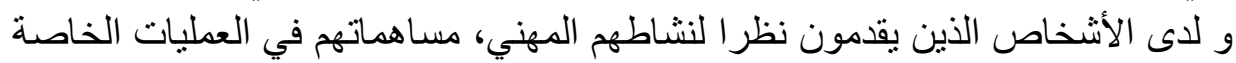

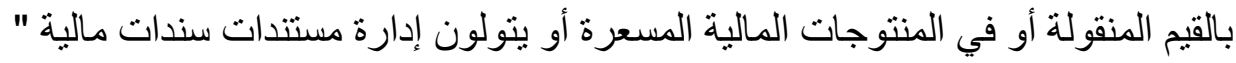

إن التحقيقات التي تقوم بها لجنة البورصة تتعلق بوقائع أو ظروف أو ممارسات من قبل أي شخص مهما كانت صفته على أن تمس هذه الأفعال المستثرين وكذان النها السير

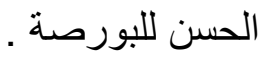

وحسب المادة 37 من المرسوم التشريعي رقم 93-10، فان من بين الجهات التي

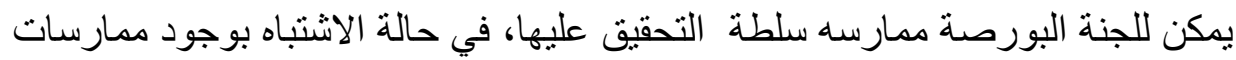

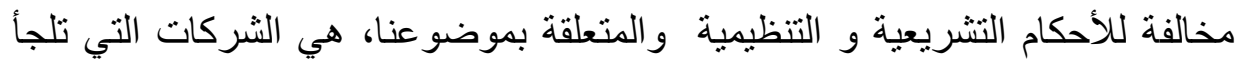

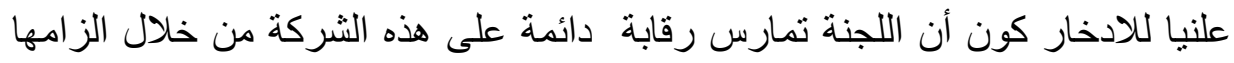

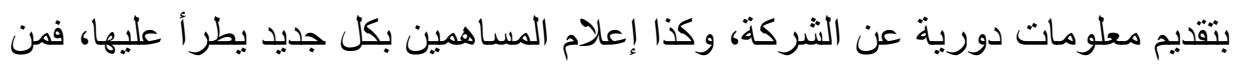

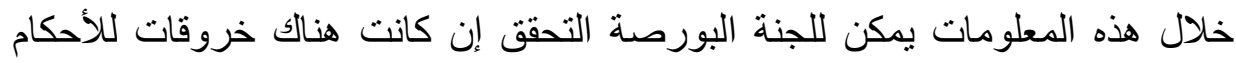
التشريعية والتظيمية، و في المقابل لا تضطلع اللجنة بأي سلطة تحقيق اتجاه الثركات غير مقيدة في البورصة و ولنئ

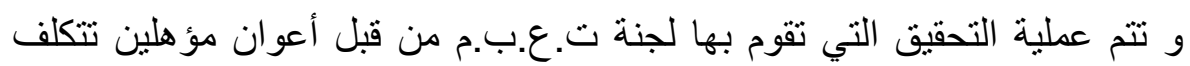

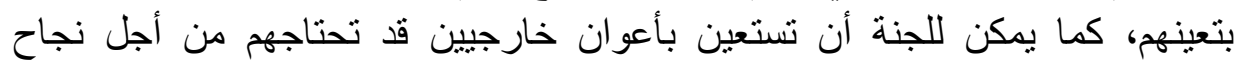

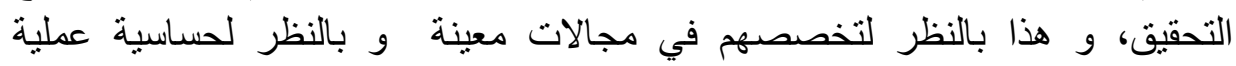

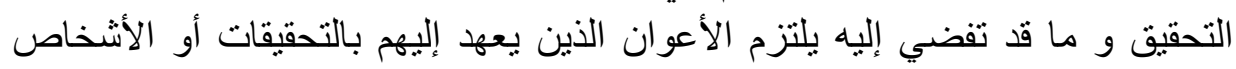

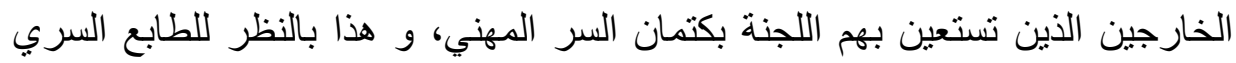

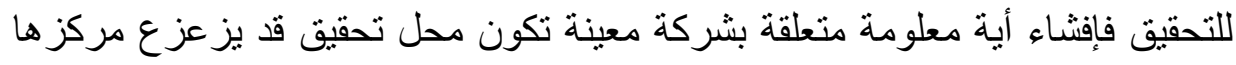

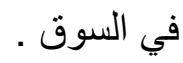
و لممارسة سلطتها في التحقيق زود المشرع اللجنة بأدوات و وسائل نمكنها من ممارسة سلطتها في التحقيق: 
ا- حق زيارة الاماكن و الحصول على الوثائق : يحق للجنة البورصة في إطار

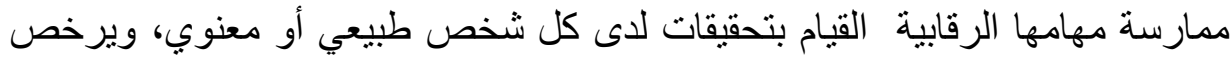

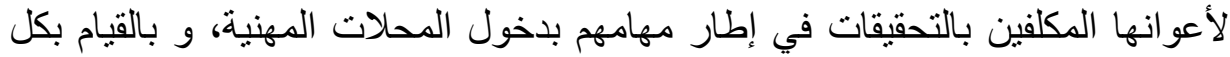

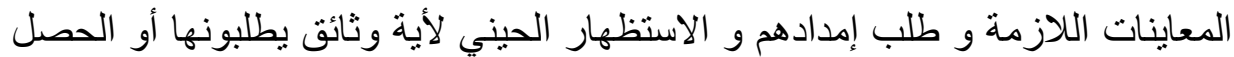
على نسخ منها .

و لا يمكن للجهات المعنية بالتحقيق التحجج بسرية بعض الوثائق لمنع المحققين من

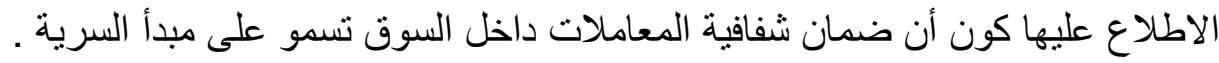
و ونح المشرع، و إضافة لصلاحية الاطلاع على الوثائق، سلطة الدخول للمحلات

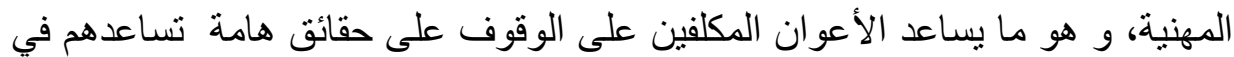

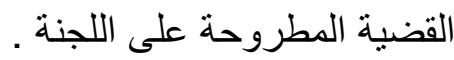

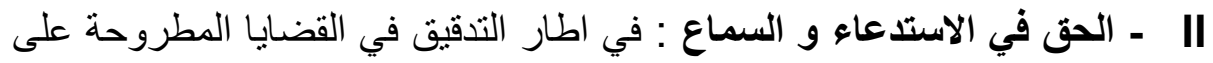

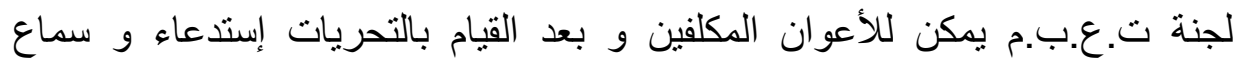

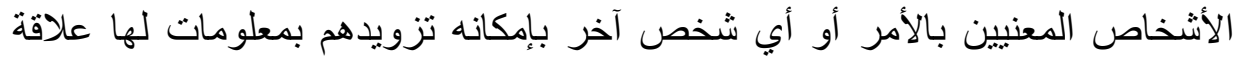

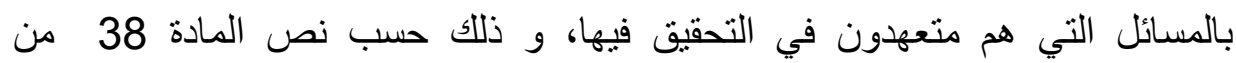

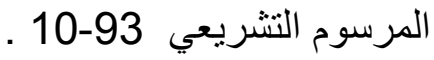

و قد جرم المشرع إعاقة محققي لجنة البورصة عن أداء مهامهم ، و هذا في نص

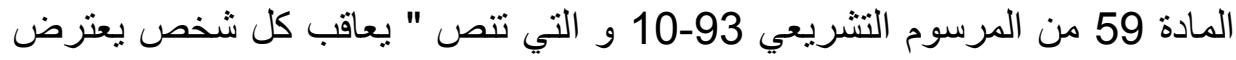

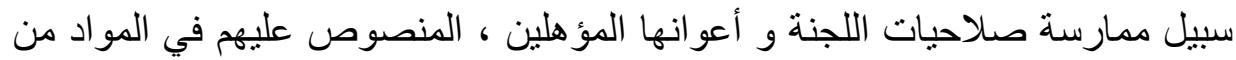

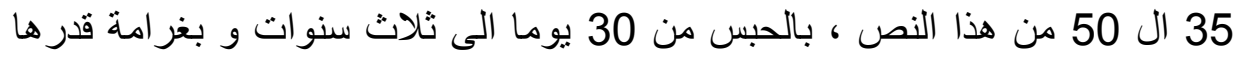
30000 دج او بإحدى العقوبتين فقط "، و هي حماية جنائية للأعوان المؤهلين الذين بلين

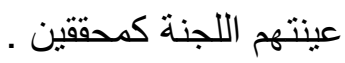

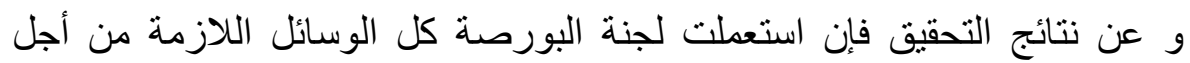

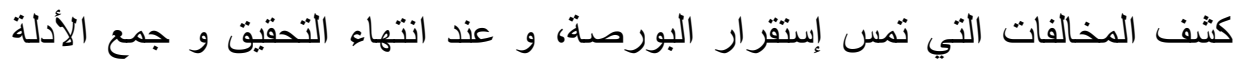

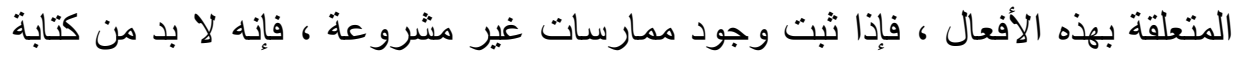

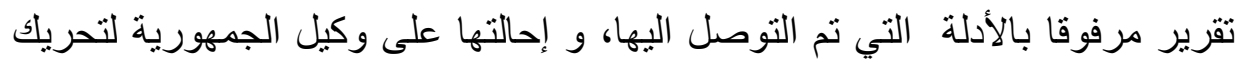

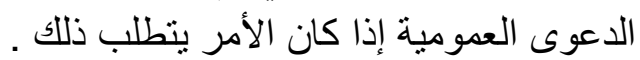

ثانيا : اللجوء للقضاء يعد العقاب وسيلة هامة لحماية المدخرين المستثمرين في

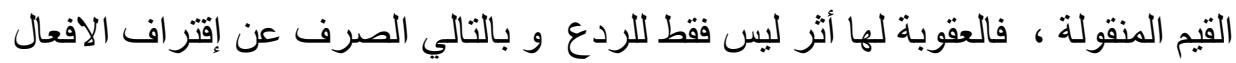


غير المشروعة، و إنما تهذف أيضا إلي إرضاء الضمير الجماعي للمستثمرين و

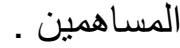

و طبقا للمادة 40 من المرسوم التشريعي 93-10 فإنه " يمكن لرئيس اللجنة في

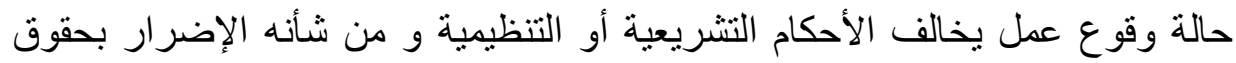
المستثمرين في القيم المنقولة، أن يطلب من المحكمة إصدار أمر للمسؤولين بامتثال هذه

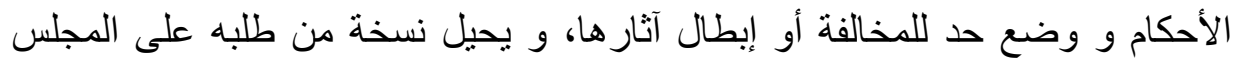
القضائي للغرض وضع الذي يقتضيه القانون.

و دون الإخلال بالمتابعات الجزائية، تفصل الجهة القضائية المختصة في الأمر إستعجاليا بل و يمكنها أن تتخذ تلقائيا أي إجراء تحفظي، و تصدر قصد تتفيذ أمرها

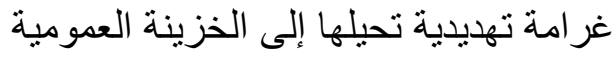

و يمكن لرئيس اللجنة أن يتأسس كطرف مدني في حالة وقوع جر ائم جزائية " و عليه و كوسيلة أخرى للرقابة على السوق و على الثركات الناثطة في البورصة

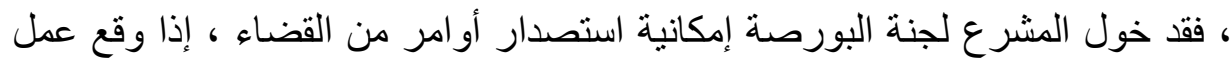
يخالف الاحكام التشريعية و التنظيمية في بورصة القيم المنقولة ، و كان من شأنة أنها

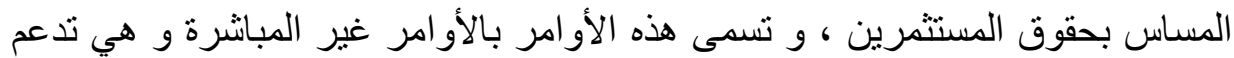

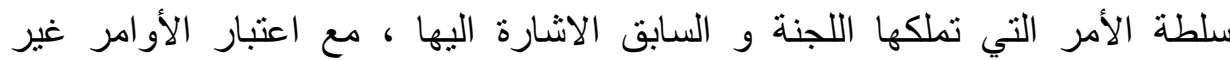

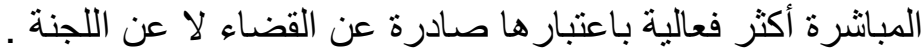

و يكون لجوء اللجنة للقضاء في الحالات التي يحظر عليها فيها إصدار أوامر مباثرة ،

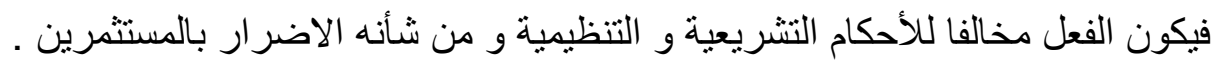
و عن الثق الجزائي فإن الجرائم المقترفة في بورصة القيم المنقولة هي جرائم

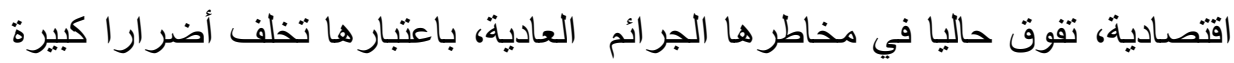
بالاقتصاد الوطني و المستثمرين في القيم المنقولة، مما يقتضي وضئ فاعنع آليات لمكافحتها و التصدي لها . ولادي الوطني

و عن دور لجنة تتظيم عمليات البورصة و مر اقبتها في مكافحة هذه الجرائم، فإنه و

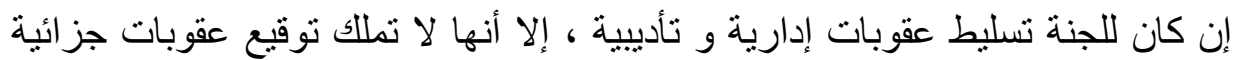
على الممارسات غير المشروعة المرنكبة في البورصة ، ذلك أن هذا الاختصاص هو إنهات 
لكن وبالر غم من ذللك فللجنة دور هام في الكثف عن هذه الممارسات عن طريق ما

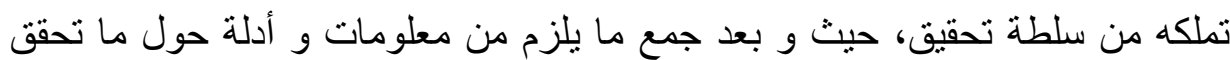

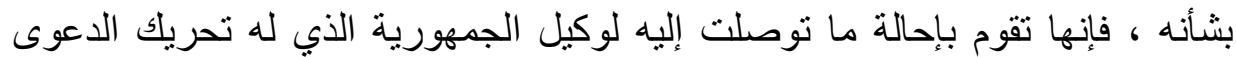

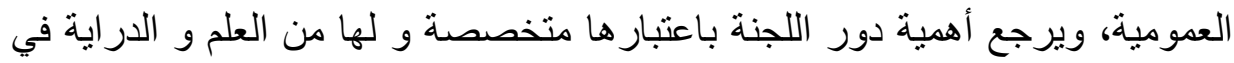

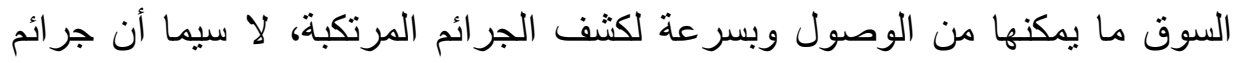

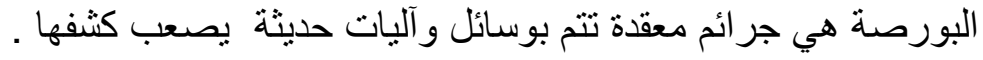

و عن جرائم البورصة و الممارسات غير المشروعة فيها، فهي تتضمن إعتداءا على حقوق المساهمين و المدخرين، و على على حسن سير السوق و و أمانها، و و على مبدأ

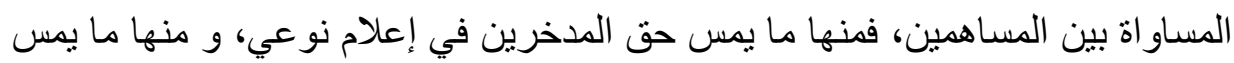
حقهم في سعر عادل لأسهمهم، و يمكن أن نذكر من هذه هن الجر ائم : - جريمة نشر معلومات خاطئة او مظللة (77) ، و عقوبتها الحبس من 6 اثهر

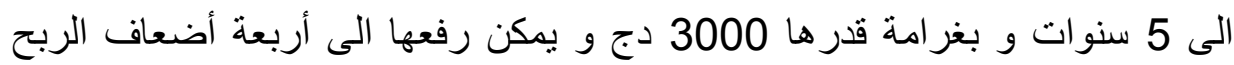

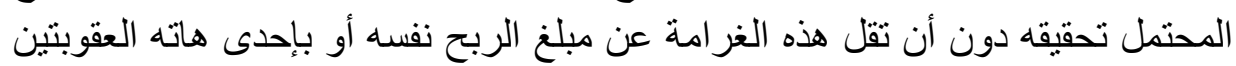

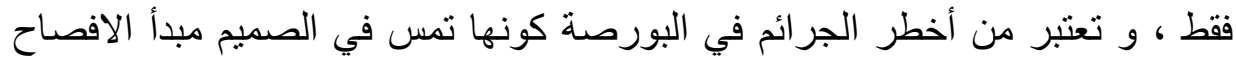

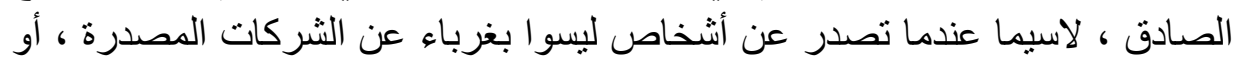

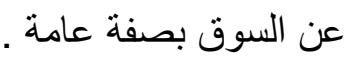

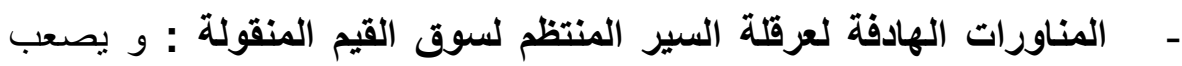

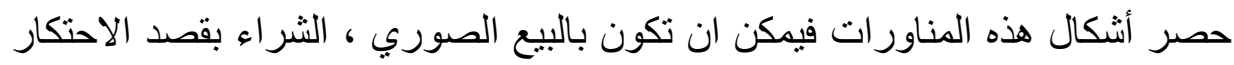

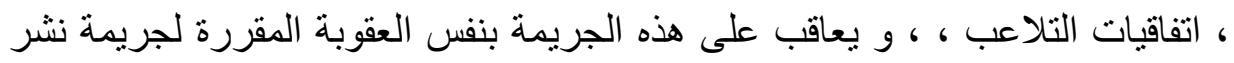

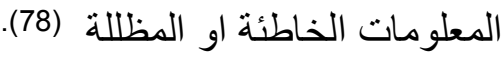

- جريمة استغلال معلومات امتيازية : و هي من أكثر الجرائم إضرارا بالسوق

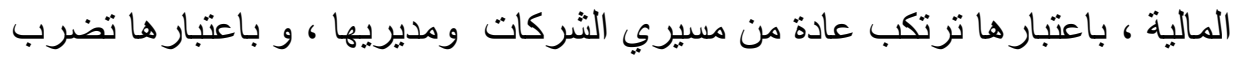

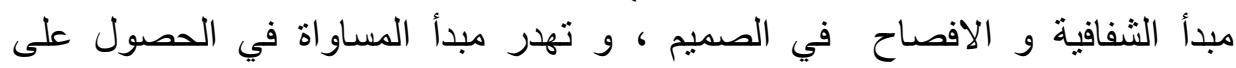

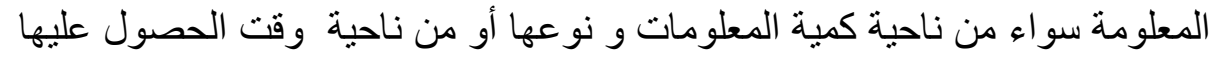

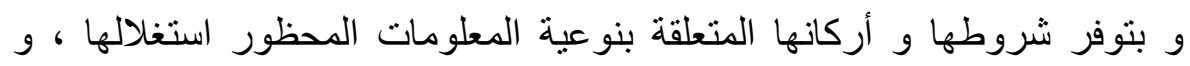

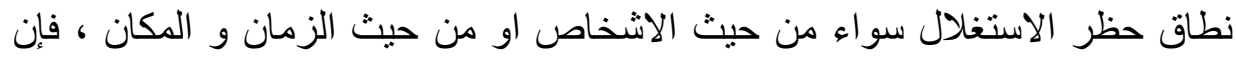

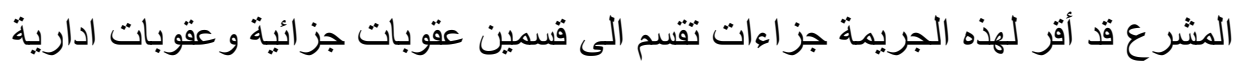

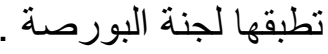


بالنسبة للعقوبات الجزائية نصت عليها المادة 60 من المرسوم التشريعي 93-10

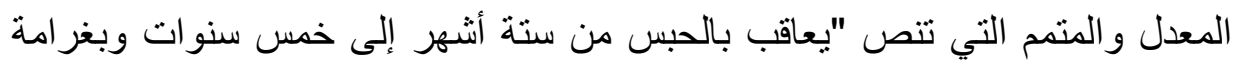

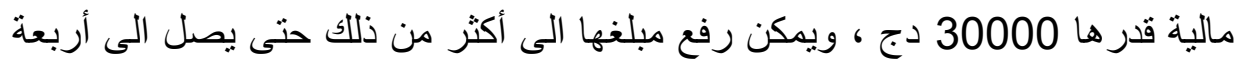

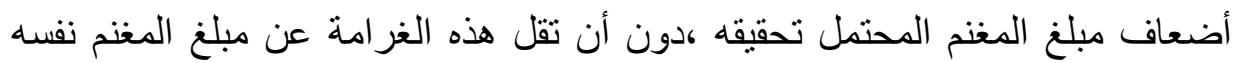

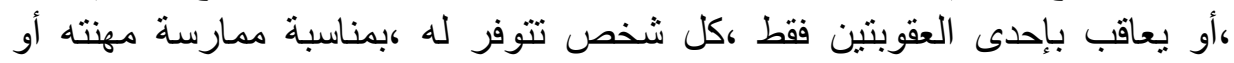

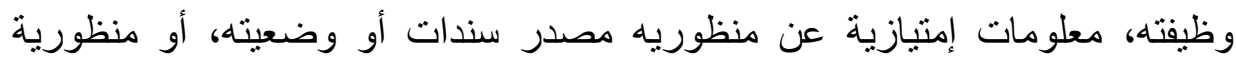

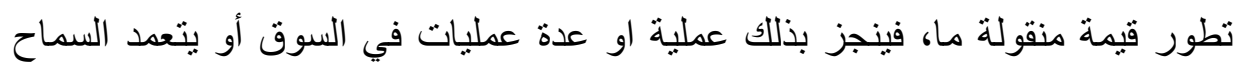

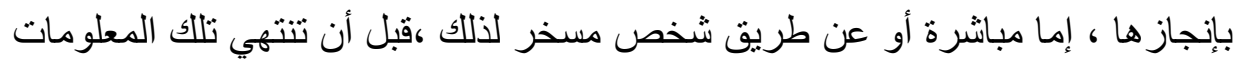
إلى الجمهور ، تعد العمليات التي تتجز على هلى هذا الأساس عمليات باطلة .

: الخاتمة :

تشكل شركات المساهمة عصب الإقتصاد الحديث ، باعتبار ها شركات أموال تقوم

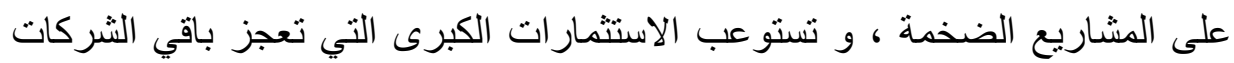

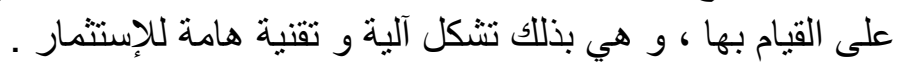

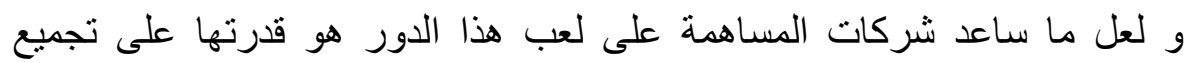
رؤوس الأموال الضخمة و ذلك بما تطرحه من أسهم و سندات ، التي تمتاز بضآلة التهاع

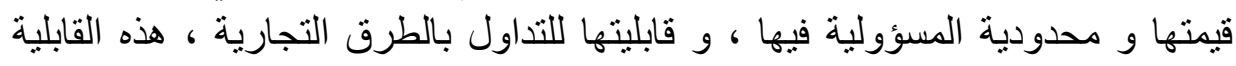

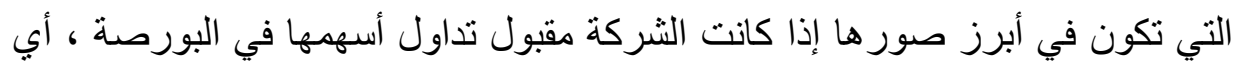
سوق المال .

و لأن شركات المساهمة تستوعب عددا هاما من الثركاء و هم المساهمون ، فإن

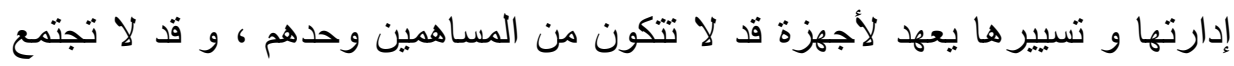

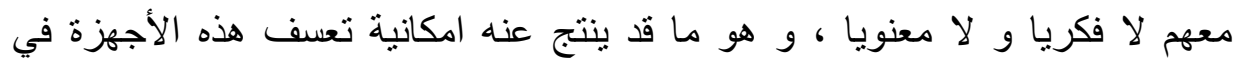

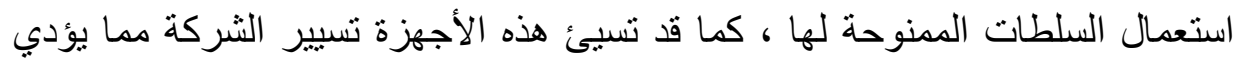

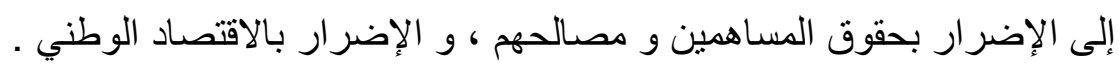

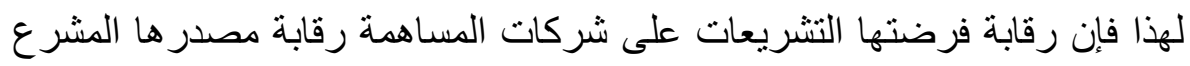

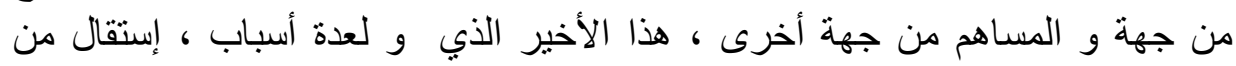

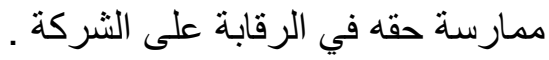


و تزيد الرقابة أهمية إذا كانت الثركة مقبولة في بورصة القيم المنقولة ، سوق

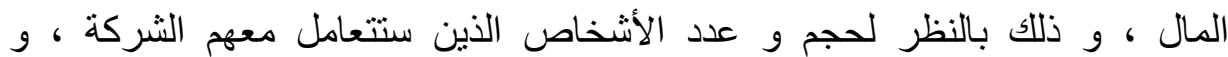
لانفتاحها على جمهور المستثرين و المدخرين في القيم المنقولة .

هؤلاء الذين ، و بالنظر لكونهم الطرف الضعيف ، يمكن أن يكونوا عرضة لممارسات

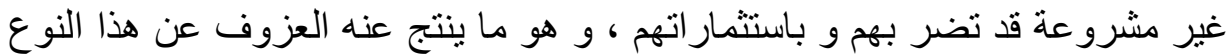

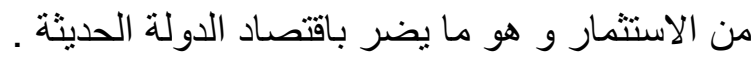

لكل ذلك فإن رقابة أخرى هامة فرضت على شركات المساهمة المدرجة أسهمها في

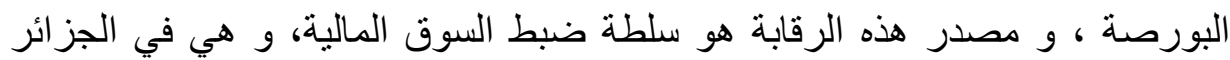
لجنة تنظيم عمليات البورصة و مراقبتها ، هذه اللجنة التي زودها المشرع الجزائه التهائري

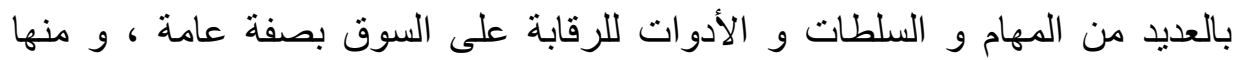

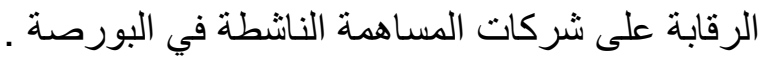

و تقسم رقابة لجنة تنظيم عمليات البورصة و مرقبتها على شركات المساهمة المقيدة

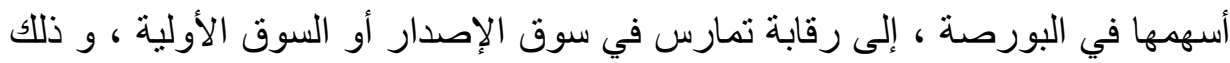

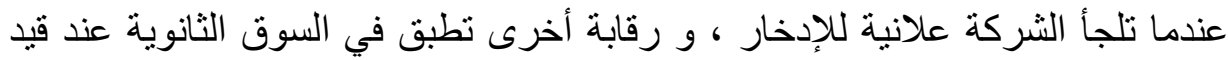

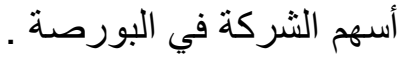
و تتمتع اللجنة في سبيل ذلك بعدة آليات ووسائل للرقابة منها قدرتها على إصدار أنظمة لتنظيم السوق ، كذلك تمتعها بسلطة الأمر و الحلول ، و سلطة التحقيق ، و و

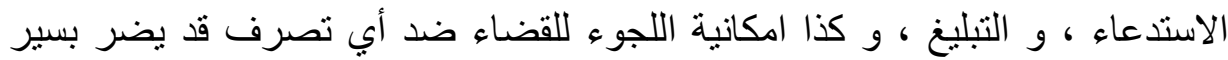
السوق و مصلحة المدخرين .

و في محاولة لتقييم وسائل و آليات الرقابة الممنوحة للجنة يمكن القول أن المشرع

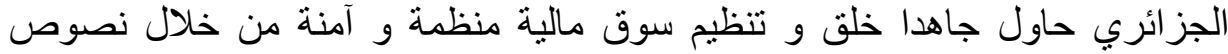

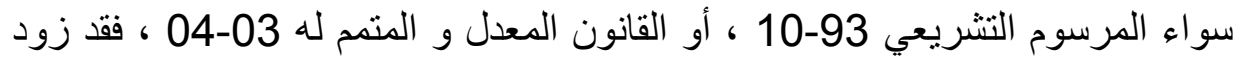

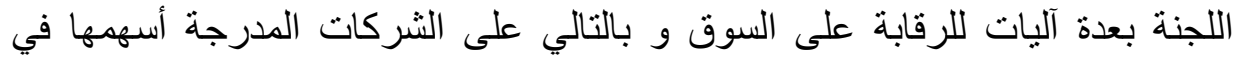

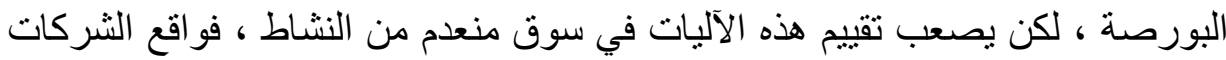

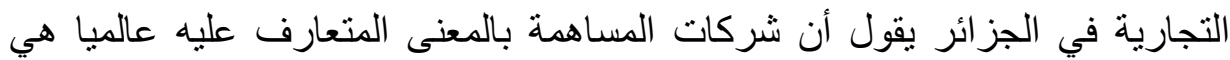
منعدمة الوجود ، فأكبر ها مملوكة للدولة باعتبار ها المساهم الوحيد فيها ، إضافة إلى إلى الصي

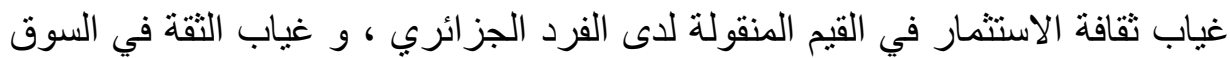

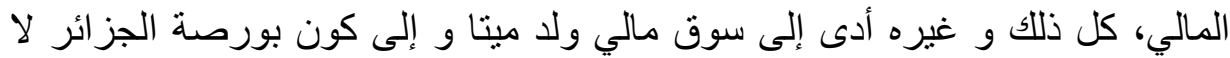


تملك من هذا الاسم إلا المكان الذي يتواجد فيه مقرها ، و هو ما لا يمكن معه تقييم

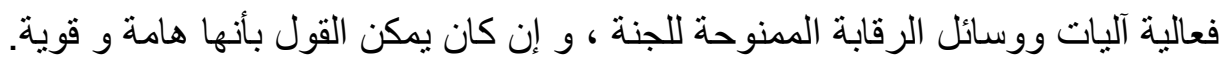

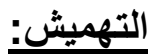

1- صاطوري الجودي ، أثر كفاءة سوق رأس المال على الإستثمار في الأوراق المالية

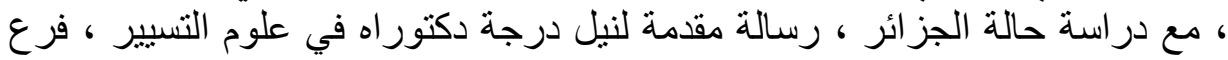

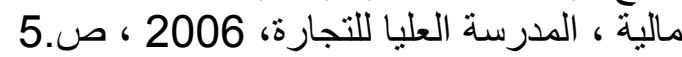
2- محمود فهمي ، تطوير سوق الأوراق المالية في مصر ووسائل و أساليب تنميتها ،

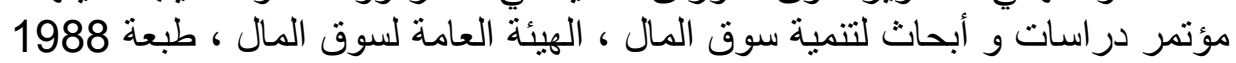

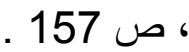

3- أحمد محمد لطفي أحمد ، معاملات البورصة بين النظم الوصفية و الأحكام الثر عية

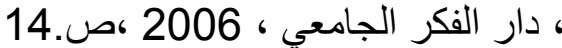

- Un détenteur de capitaux qui affecte ses capitaux a des 4 emploi étrangers a son activité professionnelle ou a sa compétence dans l'espoir d'en tirer profit ,

ARNAUD -Vallée Anne, la protection de l'épargnant ,thèse de doctorat univ Montpellier I , faculté de droit, 2002 ,p 13.

5- نصر علي طاحون ، شركة إدارة محافظ الأوراق المالية في مصر )در اسة تأصيلية

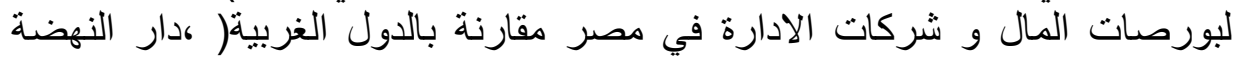

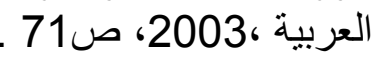

6- أنظر المادة 592 من الأمر 75-59 المؤر خ في 20 رمضان المان عام 1395 الموافق

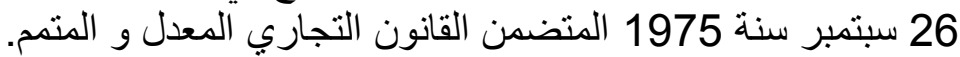

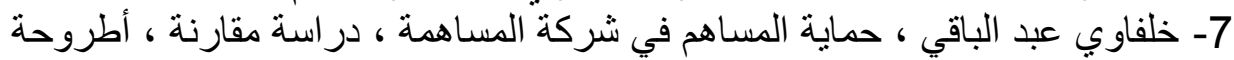
مقدمة لنيل شهادة دكتور اه علوم في القانون ، كلية الحقوق ، جامية الهعة الاخوة منتوري

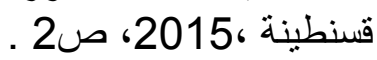
8- آيت مولد فاتح ، حماية الادخار المستثمر في القيم المنقولة في القانون الجزائري،

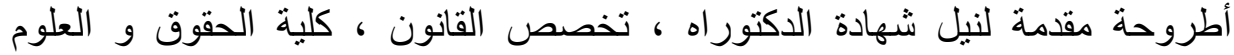

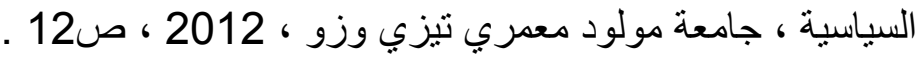

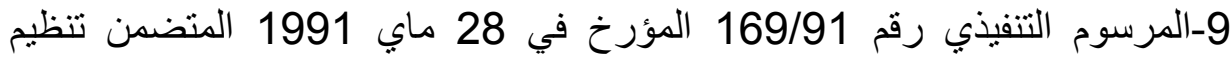

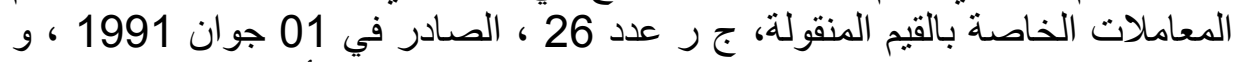
المرسوم التنفيذي 170/91 المؤرخ في 28 ماي 1991 يحدد أنواع القيم المنقولة و 
أشكالها و شروط إصدار شركات المرسوم التنفيذي 170/91 المؤرخ في 28 ماي

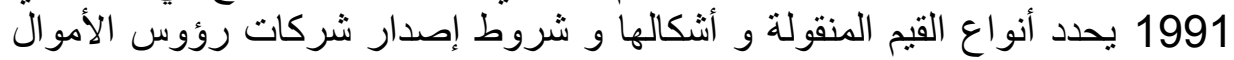

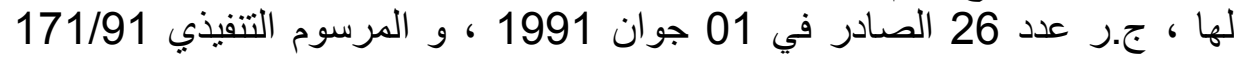
المؤرخ في 28 ماي 1991 المتعلق بلجنة البورصة ، ج. ج.ر عدد 26 الصادر في 01

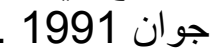

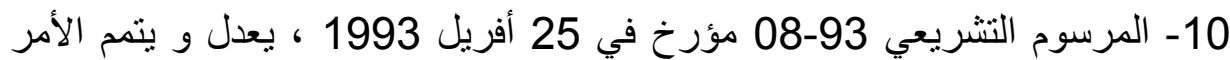

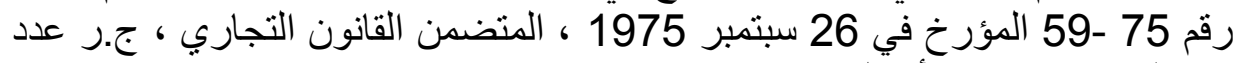
27 الصادرة في 27 أفريل .1993 في

11- هذه القيم هي : سندات المساهمة ، شهادات الإستثمار ، سندات الإستحقاق القابلة

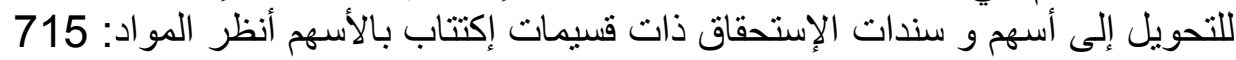

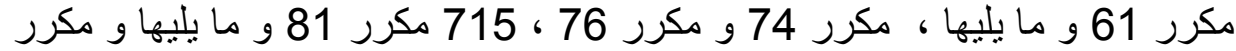
115 من القانون التجاري، و بذللك فإن المشرع الجزائري أحدث تغرئ تغييرا جذريا في

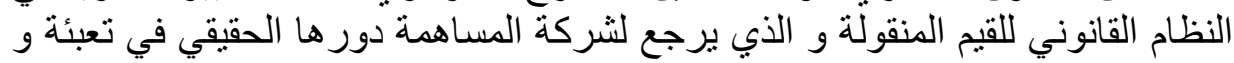
جلب الادخار

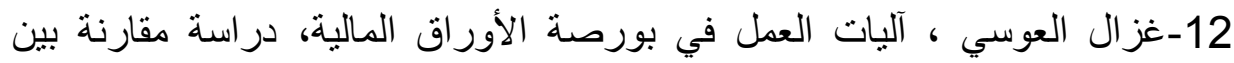
مصر و فرنسا، دار النهضة العربية ، القاهرة ، 2010 ، 2012 ، ص 34 ـ 13- المادة الأولى من المرسوم التشريعي 93-10 المعدل و المتمم. 14- جمال عبد العزيز العثمان، الافصاح والثفافية في المعلومات المتعلقة بالأوراق

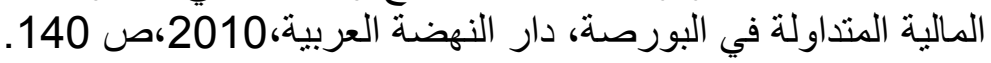

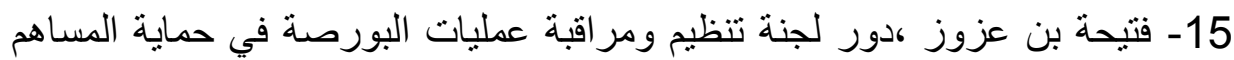

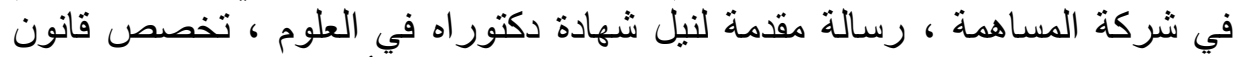
خاص ، كلية الحقوق و العلوم السياسية _ _ جامعة أبو بكر بلقايد تلمسان،

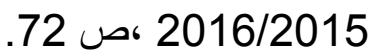

16-belletrant bernard, la bourse , Edition Hatier ,paris, .1 1992, p 56

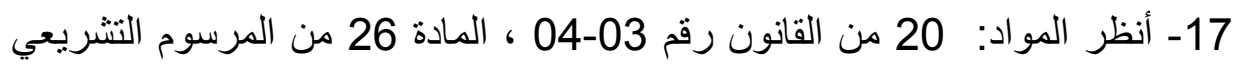
10-93، المادة 7 من نظام اللجنة رقم

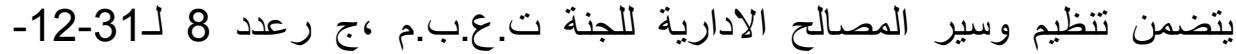


18- الزرري عبد النافع وغازي توفيق فرح ، الأسواق المالية ، دار وائل للنشر ،

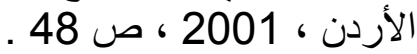

19- عاثور عبد الجواد عبد الحميد ، بعض جوانب النظام القانوني لأسواق رأس

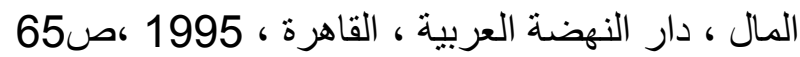

20- أنظر المو اد من 559 إلى 604 ، ومن 687 إلى 708 من القانون التجاري. 21- نظام لجنة ت.ع.ب.م رقم 92-02 المؤرخ في 22 يونيو 1996، بتعلق بالإعلام

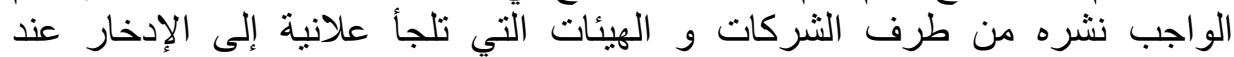

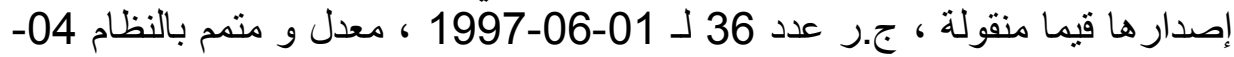
01 المؤرخ في 08 جويلية 2004 ، ج.ر عدد 22لـ 27-01-03-2005 .

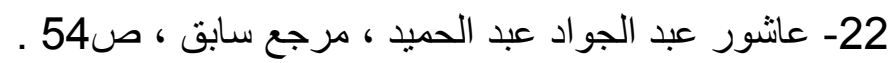

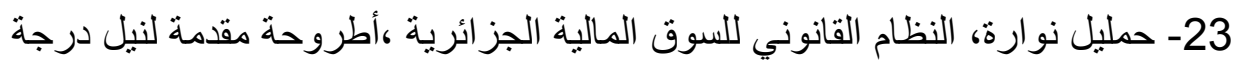

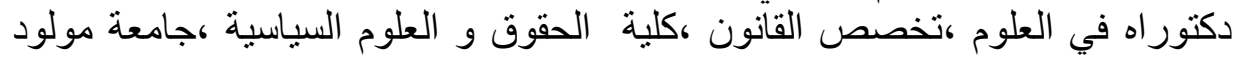

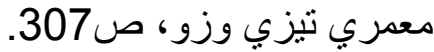

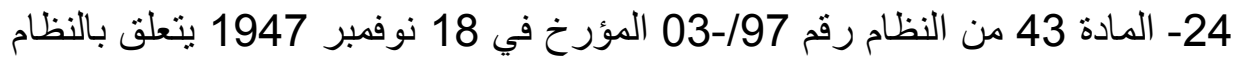

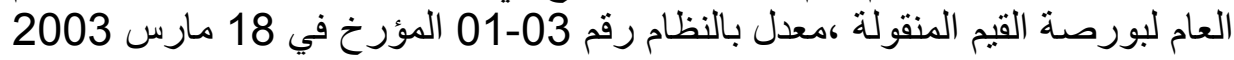

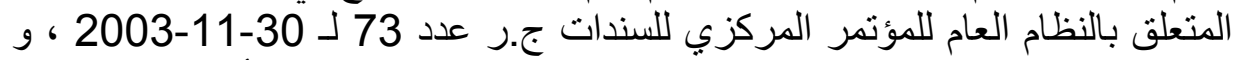

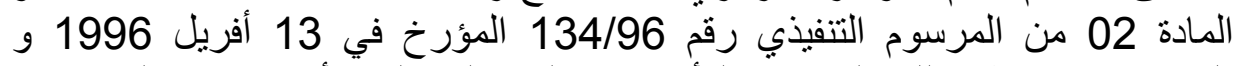

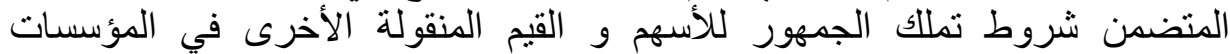

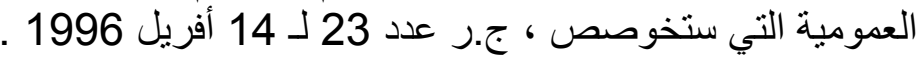

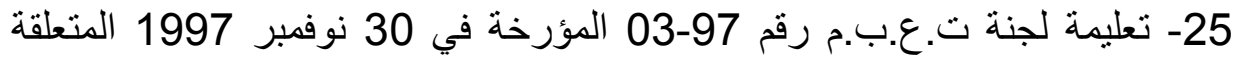
بتطبيق نظام لجنة ت.ع.ب.ب.م رقم

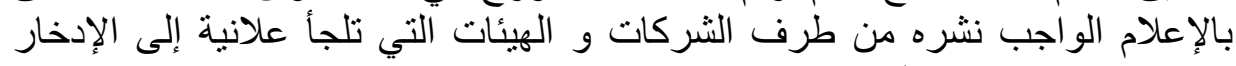

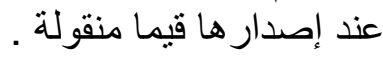

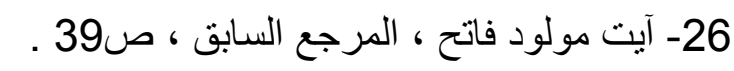
27- أنظر تعليمة اللجنة رقم 97-03 28- أنظر المادنان 11 و 13 من نظام لجنة ت.ع.ب.م رقم -92-02 . 
29- من بين التأثيرات التي منحتها لجنة تنظيم عمليات البورصة و مراقبتها

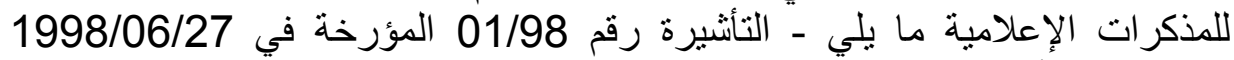
لعملية رفع ر أسمال مؤسسة رئية رياض سطيف بواسطة نداء عام للإدخار . ـ تأثنيرة رقم 02/98 المؤرخة في 1998/10/15 المتعلقة بالعرض العمومي للبيع لمجمع تنبير فندق الأوراسي.

ـ تأثيرة رقم 02/10 المؤرخة في 8 أوت 2010 لعملية رفع رأسمال شركة أليونس لألتأمينات - نأثيرة رقم 03/15 المؤرخة في 02 ديسمبر 2015 المتعلقة بالعرض العمومي

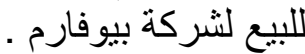
30- نظام لجنة تنظيم عمليات البورصة و مر اقبتها رقم 032 / 01-03 المؤرخ في 08 ليوليو 2004 ،ج ر عدد 22 ل : 27 / 2005 / 2030 31- بن عزوز فتيحة ، المرجع السابق ، ص 265 ـ 32- المادة 7 من نظام لجنة ت.ع.ب.م رقم -02-02. 33- آيت مولود فاتح ،المرجع السابق ، ص41 ـ

34- محمد تنوير الرافعي ، صغار المستثمرين و دور هيئة سوق المال في حمايتهخ

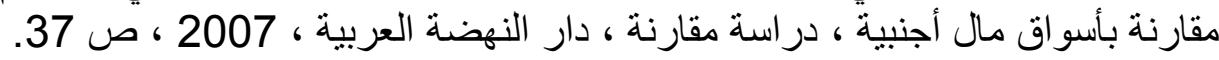
35- نظام لجنة ت.ع.ب.م رقم 2000-02 المؤرخ في 20 يناير سنة 2000 و و

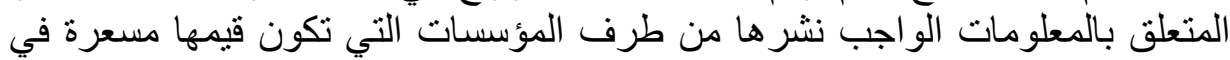
البورصة .

36- كما تدخل المشرع الجزائري و قام بإصلاح عميق في هذا الميدان بصدور القانون

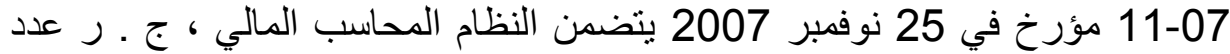
.2007-11-25 74

$$
\text { 37- المادة } 6 \text { فقرة } 1 \text { من نظام اللجنة 2000-202 . }
$$

38- المادة 5 من نظام اللجنة 2000-02 المتعلق بالمعلومات الواجب نشرهات ها من

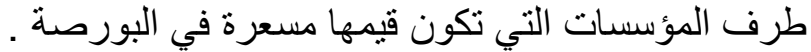
39- المادة 2 من نظام اللجنة رقم 2000-02. 
40- المادة 3 من نظام اللجنة رقم 2000-02 .

41- أنظر المواد من 687 إلى 691 و 697 من القانون التجاري .

42- المادة 678 من القانون التجاري .

43- المادة 65 مكرر 1 من القانون 03-03 المعدل و المتمم للمرسوم التشريعي 9310 المتعلق ببورصة القيم المنقولة .

44- مرسوم تتفيذي رقم 08-156 المؤرخ في 26 ماب 2008 ، 2007 ، يتضمن تطبيق

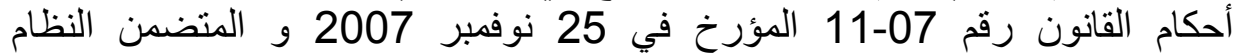
المحاسب المالي ، ج .ر عدد 27 لـ 28-05-2008 في

45- آيت مولود فاتح ، المرجع السابق ، ص .337

-DECOOPMAN NICOL «le pouvoir d'injonction des 46 $44,{ }^{\circ}$ autorités administratives indépendantes » J . C.P.G.N 1987 , Doc , p 3303.

47- وليد بوجملين ، سلطات الضبط الإقتصادي في القانون الجزائري ، دار بلقيس ،

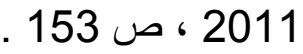

48- كالتشريع التونسي ، أنظر الفصل 82 من القانون عدد 117 لسنة 1994 المتعلق

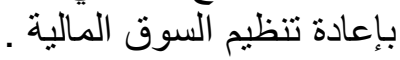

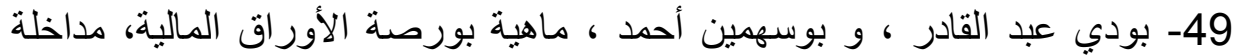

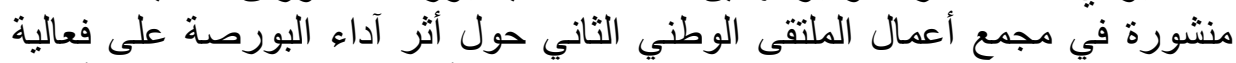

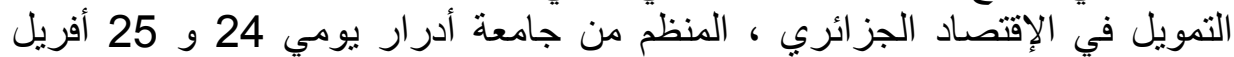

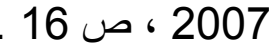

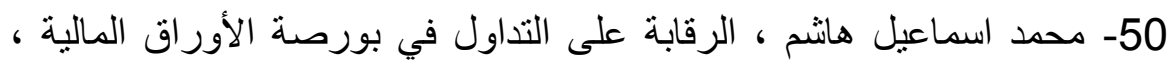
دراسة قانونية مقارنة بين النظام المصري و الأمريكي ، القاهرة ، 2011 ، ص ص الأل

404

51- طاهر شوقي مؤمن ،الإستحواذ على الثركة (دراسة نظرية و نطبيقية )،دار النهضة العربية ، ألقاهرة ، 2009 ، صن صن 59 ـ 52- المادة 77 من نظام اللجنة رقم 97-03 المتعلق بالنظام العام للبورصة . 


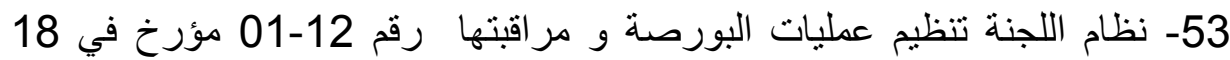

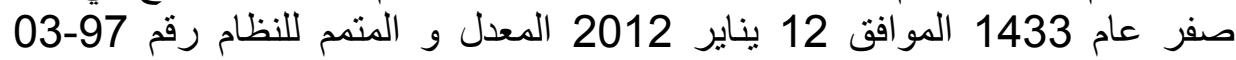
المؤرخ في 17 رجب عام 1433 رجو الموافق 1818 نوفمبر 1997 المتعلق بالنظام العام لبورصة القيم المنقولة ف

54- المادة 30 من النظام 97-03 المعدلة بموجب المادة 6 من النظام 12-01 .

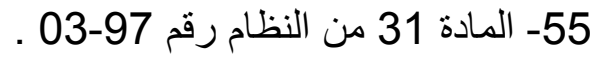
56- المادة 34 من النظام رقم 03-97 . 57- المادة 36 من النظام رقم 03-97 . 58- المواد 37 ، 38 ، 39 من النظام رقم 97-03 .

59- المادة 07 فقرة أولى من النظام رقم 12-012 المعدلة للمادة 43 من النظام رقم 03-97 التي كانت نتشرط ألا يقل رأسمال الثركة عن مائة مليون دينار جزائري . (100.000.000) 60- المادة 7 فقرة ثانية من النظام رقم 12-01 المعدلة للمادة 43 من النظام 97-03

$$
\begin{aligned}
& \text { 61- المعدلة بالمادة } 3 \text { من النظام رقم 12-01 . } \\
& \text { 62- المادة } 33 \text { من النظام 97-03 . }
\end{aligned}
$$

63- المادة 8 من النظام 12-01 المعدلة للمادة 44 من النظام 97 -03 ـ

64- القانون رقم 01-18 المؤرخ في 12 ديسمبر 2001 ، المتضمن القونة القانون

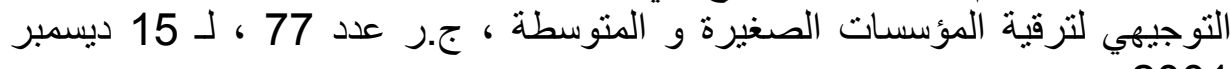
2001 65- المادة 46 من النظام رقم 01-97 المستحدثة بموجب المادة 9 من النظام رقم $01 .-12$ 66- المادة 01-46 من النظام رقم 03-97 المستحدثة بموجب المادة 9 من النظام

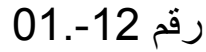
67- التعليمة الصادرة عن اللجنة تحت رقم 2013 /013 المؤرخة في 09 جوان 2013 ، المتضمنة شروط و إجرة إعات تسجيل راعي البورصة . 
68- المادة 36-03 من النظام رقم 97-03 المستحدثة بموجب النظام رقم 12-01 . 69- المادة 46-46 المستحدثة بموجب النظام 12-01 . 70- المواد 46-46 ، 46-61 من النظام رقم 97-03 المستحدثة بموجب النظام رقم . 01-12 71- المادة 46-76 من النظام رقم 97-03 المستحدثة بموجب النظام رقم 12-01 . 72- حمليل نوارة ، المرجع السابق ، ص 362 ـ 32

73- تعليمة لجنة تنظيم عمليات البورصة و مر اقبتها رقم 98-01 المؤرخة في 30 أفريل 1998 المتعلقة بقبول القيم المنقولة للتداول في البورية البورصة . 74- المادة 30 من النظام رقم 03-97 . 75- المادة 42 من المرسوم التشريعي رقم 93-10 المتعلق ببورصة القيم المنقولة . 76- بن عزوز فتيحة ، المرجع السابق ، ص .476 77- المادة 60 من المرسوم التشريعي 93-10 المعدل و المتمم بموجب القانون 0304

78- المادة 60 فقرة 3 من المرسوم التشريعي 93-03-10 المعدل و المتمم بموجب

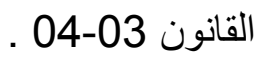

